Prepared in cooperation with the Rhode Island Water Resources Board

\title{
Numerical Simulation of Groundwater and Surface-Water Interactions in the Big River Management Area, Central Rhode Island
}

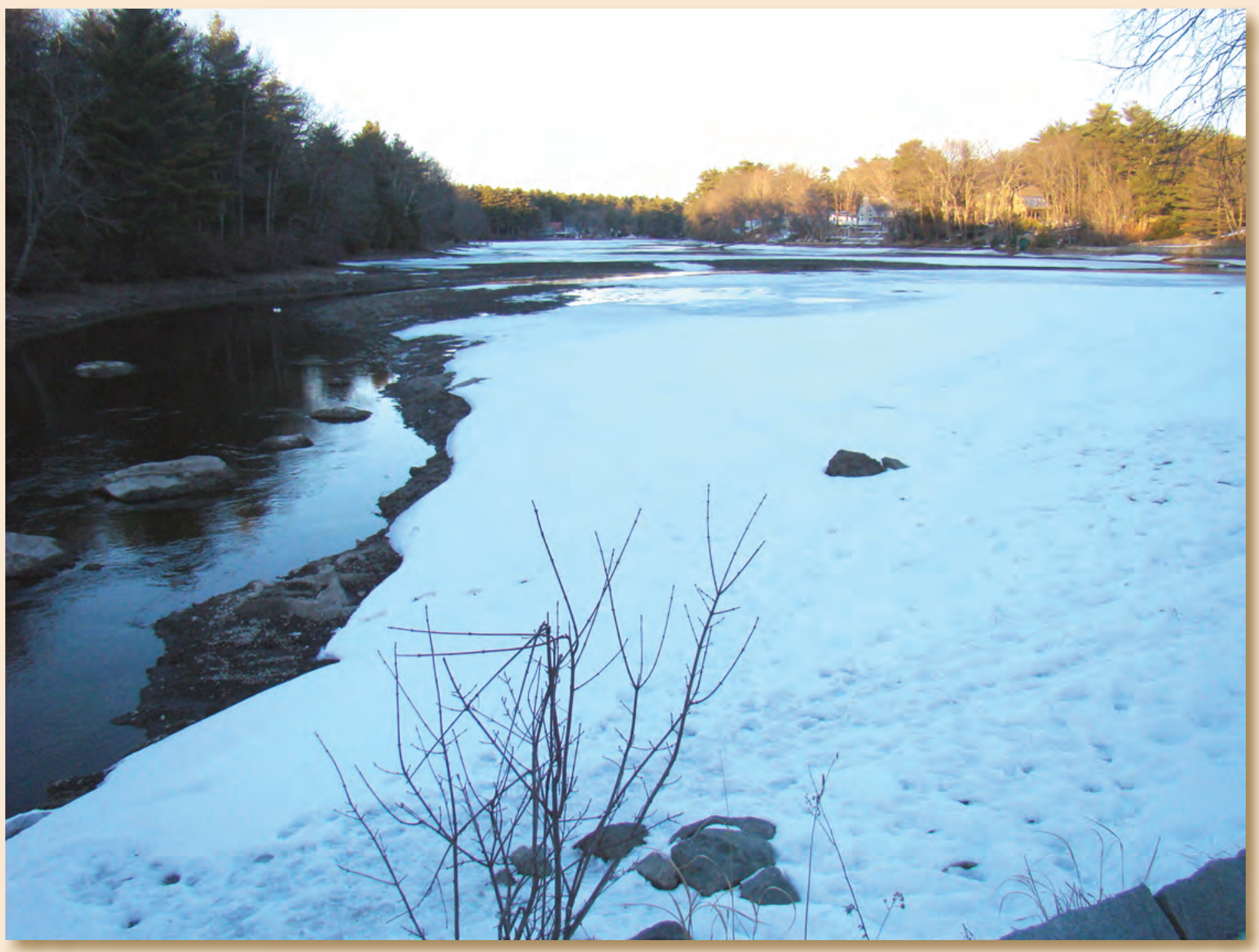

Scientific Investigations Report 2012-5077 
Cover Big River at Harkney Hill Road in Coventry, Rhode Island in February 2010 when the stage in the Flat River Reservoir was low and streamflow was limited to the river channel. 


\section{Numerical Simulation of Groundwater and Surface-Water Interactions in the Big River Management Area, Central Rhode Island}

By John P. Masterson and Gregory E. Granato

Prepared in cooperation with the Rhode Island Water Resources Board

Scientific Investigations Report 2012-5077 


\title{
U.S. Department of the Interior \\ Sally Jewell, Secretary
}

\section{U.S. Geological Survey \\ Suzette M. Kimball, Acting Director}

\author{
U.S. Geological Survey, Reston, Virginia: 2013
}

For more information on the USGS - the Federal source for science about the Earth, its natural and living resources, natural hazards, and the environment, visit http://www.usgs.gov or call 1-888-ASK-USGS.

For an overview of USGS information products, including maps, imagery, and publications, visit http://www.usgs.gov/pubprod

To order this and other USGS information products, visit http://store.usgs.gov

Any use of trade, product, or firm names is for descriptive purposes only and does not imply endorsement by the U.S. Government.

Although this report is in the public domain, permission must be secured from the individual copyright owners to reproduce any copyrighted materials contained within this report.

Suggested citation:

Masterson, J.P., and Granato, G.E., 2013, Numerical simulation of groundwater and surface-water interactions in the Big River Management Area, central Rhode Island: U.S. Geological Survey Scientific Investigations Report 2012-5077, 53 p., http://pubs.usgs/sir/2012/5077/. 


\section{Contents}

Abstract
Introduction
Sydrogeologylation of Groundwater and Surface-Water Interactions
Development of the Groundwater Model
Model Discretization and Boundary Conditions
Spatial Discretization
Hemporal Discretization
Hydraulic Properties
Hydrologic Stresses
Pecharge

\section{Figures}

1. Map showing location of Big River Management Area, central Rhode Island, and model-calculated water levels for long-term average conditions.

2. Schematic diagram of a hypothetical aquifer showing groundwater discharge to a surface-water body with $A$, no pumping; $B$, pumping at a rate (01) such that the well would capture water that otherwise would discharge to the surface-water body; and C, pumping at a higher rate (02) so that the flow direction is reversed and the well pumps water from the surface-water body

3. Map showing model extent and distribution of simulated boundary conditions of groundwater-flow model of Big River Management Area, central Rhode Island .............6

4. Sections showing vertical layering and model representation of geologic sections $A-A^{\prime}$ and $B-B^{\prime}$

5. Photographs showing Big River at Harkney Hill Road, Coventry, Rhode Island ................9 
6. Map showing surficial geology of the Big River Management Area, central Rhode Island.

7. Geologic sections (A-A' and $\left.B-B^{\prime}\right)$ showing the distribution of stratified glacial deposits in the Big River Management Area, central Rhode Island.

8. Graph showing monthly values of precipitation and calculated aquifer recharge at the T.F. Green Airport weather station, Providence, Rhode Island, from 1960 through 2006 .

9. Map showing locations of water-level and streamflow sites used for model calibration and model-calculated water-level contours for long-term average conditions, Big River Management Area, central Rhode Island

10. Graphs showing comparison of $A$, model-calculated and estimated water levels, and $B$, residual (estimated minus model calculated) water levels as a function of estimated water levels for long-term average conditions.

11. Graphs showing comparison of monthly departure from average conditions for model-calculated and estimated water levels for observation wells A, WGW285; B, WGW286; C, WGW 287; D, WGW 290; E, WGW291; F, WGW293; G, WGW303; H, WGW304; I, WGW305; J, WGW313; and K, WGW320 in the Big River Management Area, central Rhode Island

12. Graph showing comparison of changes in model-calculated and estimated vertical gradients with time at A, Reynolds Pond Swamp (WGW427); B, Cedar Swamp (WGW428); and C, Scarborough Swamp (WGW426), Big River Management Area, central Rhode Island

13. Graphs showing comparison of model-calculated and estimated streamflows for long-term average monthly conditions from 1960 through 2006 in the Big River Management Area, central Rhode Island

14. Map showing location of test wells WGW443 and WGW444 and monitoring wells measured during the aquifer test conducted from December 16 to 21, 2009, and model-calculated water-level changes in response to 5 days of simulated pumping in the Big River Management Area, central Rhode Island

15. Graph showing comparison between measured and model-calculated water-level changes with distance at monitoring wells measured at the end of the 5-day aquifer test conducted from December 16 to 21, 2009, Big River Management Area, central Rhode Island.

16. Graph showing comparison between measured and model-calculated waterlevel changes with distance at monitoring wells measured at the end of the 5-day aquifer test conducted from December 16 to 21, 2009, Big River Management Area, central Rhode Island. A, WGW445; B, WGW412; C, WGW413; D, WGW371; E, WGW416; and F, WGW427.

17. Maps showing model-calculated water-level declines $A$, after 5 days of continuous pumping for December conditions when reservoir area is drained and $B$, in response to continuous pumping for long-term average December conditions when reservoir area is drained, Big River Management Area, central Rhode Island...

18. Maps showing model-calculated water-level declines in response to continuous pumping for $A$, long-term average December conditions when reservoir area is drained and for $B$, long-term average August conditions when reservoir area is flooded, the Big River Management Area, central Rhode Island 


\section{Tables}

1. Horizontal hydraulic conductivity and horizontal to vertical anisotropy values of the lithologic units used in the groundwater-flow model of the Big River Management Area, central Rhode Island

2. Measured and model-calculated water-level declines in response to 5 days of continuous pumping at pumping test sites WGW443 and WGW444, Big River Management Area, central Rhode Island...

3. Source of water to pumping wells at a total pumping rate of $1.5 \mathrm{Mgal} / \mathrm{d}$ after 5 days of pumping and for long-term monthly conditions

4. Model-calculated water-level declines at the priority wetland sites in response to continuous pumping at aquifer test sites WGW443 and WGW444 for short-term (5 days) and average monthly conditions, Big River Management Area, central Rhode Island 


\section{Conversion Factors, Datum, and Acronyms}

\begin{tabular}{|c|c|c|}
\hline Multiply & By & To obtain \\
\hline \multicolumn{3}{|c|}{ Length } \\
\hline inch (in.) & 2.54 & centimeter $(\mathrm{cm})$ \\
\hline foot $(\mathrm{ft})$ & 0.3048 & meter $(\mathrm{m})$ \\
\hline mile (mi) & 1.609 & kilometer $(\mathrm{km})$ \\
\hline \multicolumn{3}{|c|}{ Area } \\
\hline square mile $\left(\mathrm{mi}^{2}\right)$ & 2.590 & square kilometer $\left(\mathrm{km}^{2}\right)$ \\
\hline \multicolumn{3}{|c|}{ Volume } \\
\hline gallon (gal) & 0.003785 & cubic meter $\left(\mathrm{m}^{3}\right)$ \\
\hline million gallons (Mgal) & 3,785 & cubic meter $\left(\mathrm{m}^{3}\right)$ \\
\hline cubic foot $\left(\mathrm{ft}^{3}\right)$ & 0.02832 & cubic meter $\left(\mathrm{m}^{3}\right)$ \\
\hline \multicolumn{3}{|c|}{ Flow rate } \\
\hline foot per day (ft/d) & 0.3048 & meter per day $(\mathrm{m} / \mathrm{d})$ \\
\hline cubic foot per second $\left(\mathrm{ft}^{3} / \mathrm{s}\right)$ & 0.02832 & cubic meter per second $\left(\mathrm{m}^{3} / \mathrm{s}\right)$ \\
\hline $\begin{array}{l}\text { cubic foot per second per square mile } \\
\qquad\left[\left(\mathrm{ft}^{3} / \mathrm{s}\right) / \mathrm{mi}^{2}\right]\end{array}$ & 0.01093 & $\begin{array}{l}\text { cubic meter per second per square } \\
\text { kilometer }\left[\left(\mathrm{m}^{3} / \mathrm{s}\right) / \mathrm{km}^{2}\right]\end{array}$ \\
\hline gallon per minute (gal/min) & 0.06309 & liter per second $(\mathrm{L} / \mathrm{s})$ \\
\hline million gallons per day (Mgal/d) & 0.04381 & cubic meter per second $\left(\mathrm{m}^{3} / \mathrm{s}\right)$ \\
\hline inch per year (in/yr) & 25.4 & millimeter per year $(\mathrm{mm} / \mathrm{yr})$ \\
\hline \multicolumn{3}{|c|}{ Hydraulic conductivity } \\
\hline foot per day (ft/d) & 0.3048 & meter per day $(\mathrm{m} / \mathrm{d})$ \\
\hline \multicolumn{3}{|c|}{ Hydraulic gradient } \\
\hline foot per mile (ft/mi) & 0.1894 & meter per kilometer \\
\hline \multicolumn{3}{|c|}{ Transmissivity* } \\
\hline foot squared per day $\left(\mathrm{ft}^{2} / \mathrm{d}\right)$ & 0.09290 & meter squared per day $\left(\mathrm{m}^{2} / \mathrm{d}\right)$ \\
\hline \multicolumn{3}{|c|}{ Leakance } \\
\hline foot per day per foot $[(\mathrm{ft} / \mathrm{d}) / \mathrm{ft}]$ & 1 & meter per day per meter \\
\hline inch per year per foot $[(\mathrm{in} / \mathrm{yr}) / \mathrm{ft}]$ & 83.33 & millimeter per year per meter $[(\mathrm{mm} / \mathrm{yr}) / \mathrm{m}]$ \\
\hline
\end{tabular}

Vertical coordinate information is referenced to the National Geodetic Vertical Datum of 1929 (NGVD 29), formerly called Sea Level Datum of 1929.

Horizontal coordinate information is referenced to the North American Datum of 1927 (NAD 27)

Altitude, as used in this report, refers to distance above the vertical datum.

\section{List of Acronyms}

$\begin{array}{ll}\text { BRMA } & \text { Big River Management Area } \\ \text { MODFLOW } & \text { modular three-dimensional finite-difference groundwater model } \\ \text { MOVE } & \text { maintenance of variance } \\ \text { RIWRB } & \text { Rhode Island Water Resources Board } \\ \text { URI } & \text { University of Rhode Island } \\ \text { USGS } & \text { U.S. Geological Survey }\end{array}$




\title{
Simulation of Groundwater and Surface-Water Interactions in the Big River Management Area, Central Rhode Island
}

\author{
By John P. Masterson and Gregory E. Granato
}

\section{Abstract}

The Rhode Island Water Resources Board is considering use of groundwater resources from the Big River Management Area in central Rhode Island because increasing water demands in Rhode Island may exceed the capacity of current sources. Previous water-resources investigations in this glacially derived, valley-fill aquifer system have focused primarily on the effects of potential groundwater-pumping scenarios on streamflow depletion; however, the effects of groundwater withdrawals on wetlands have not been assessed, and such assessments are a requirement of the State's

permitting process to develop a water supply in this area.

A need for an assessment of the potential effects of pumping on wetlands in the Big River Management Area led to a cooperative agreement in 2008 between the Rhode Island Water Resources Board, the U.S. Geological Survey, and the University of Rhode Island. This partnership was formed with the goal of developing methods for characterizing wetland vegetation, soil type, and hydrologic conditions, and monitoring and modeling water levels for pre- and post-water-supply development to assess potential effects of groundwater withdrawals on wetlands. This report describes the hydrogeology of the area and the numerical simulations that were used to analyze the interaction between groundwater and surface water in response to simulated groundwater withdrawals.

The results of this analysis suggest that, given the hydrogeologic conditions in the Big River Management Area, a standard 5-day aquifer test may not be sufficient to determine the effects of pumping on water levels in nearby wetlands. Model simulations showed water levels beneath Reynolds Swamp declined by about 0.1 foot after 5 days of continuous pumping, but continued to decline by an additional 4 to 6 feet as pumping times were increased from a 5-day simulation period to a simulation period representative of long-term average monthly conditions. This continued decline in water levels with increased pumping time is related to the shift from the primary source of water to the pumped wells being derived from aquifer storage during the early-time (5 days) simulation to being derived more from induced infiltration from the flooded portion of the Big River (southernmost extent of the Flat River Reservoir) during the months of March through October or from captured groundwater discharge to this portion of the Big River when the downstream Flat River Reservoir is drained for weed control during the months of November through February, as was the case for the long-term monthly conditions.

\section{Introduction}

Water demand is increasing throughout Rhode Island, and the Rhode Island Water Resources Board (RIWRB), which is responsible for developing and protecting the State's water resources, is concerned that increasing demand may exceed the capacity of current sources. In the early 1960s, the State proposed construction of a surface-water reservoir south of the Flat River Reservoir in the Big River Basin in central Rhode Island to meet these growing demands. At that time, the Big River Management Area (BRMA) (fig. 1), which covers about $13.4 \mathrm{mi}^{2}$, was established under the responsibility of the Water Resources Coordinating Board, the precursor to the RIWRB. To date (2012), the U.S. Environmental Protection Agency has not given approval for construction of this reservoir. In the meantime, the RIWRB would like to develop the largely untapped groundwater resources of the basin as a possible interim alternative to a surface-water reservoir.

In an effort to better understand the hydrogeology and groundwater-development options for the BRMA, the U.S. Geological Survey (USGS) and RIWRB began a series of cooperative studies of the area in 1995. Four reports were published as part of this cooperative effort: the first report provided hydrogeologic data collected in the area from July 1996 through October 1998 (Craft, 2001); the second report described the glacial geology and hydraulic properties of the glacial sediments within the area (Stone and Dickerman, 2002); the third report (Granato and others, 2003) described the hydrogeology of the area and simulated effects of selected groundwater-development options on streamflow in the area and provided the basis for a fourth report by Granato and Barlow (2005), who described the development 


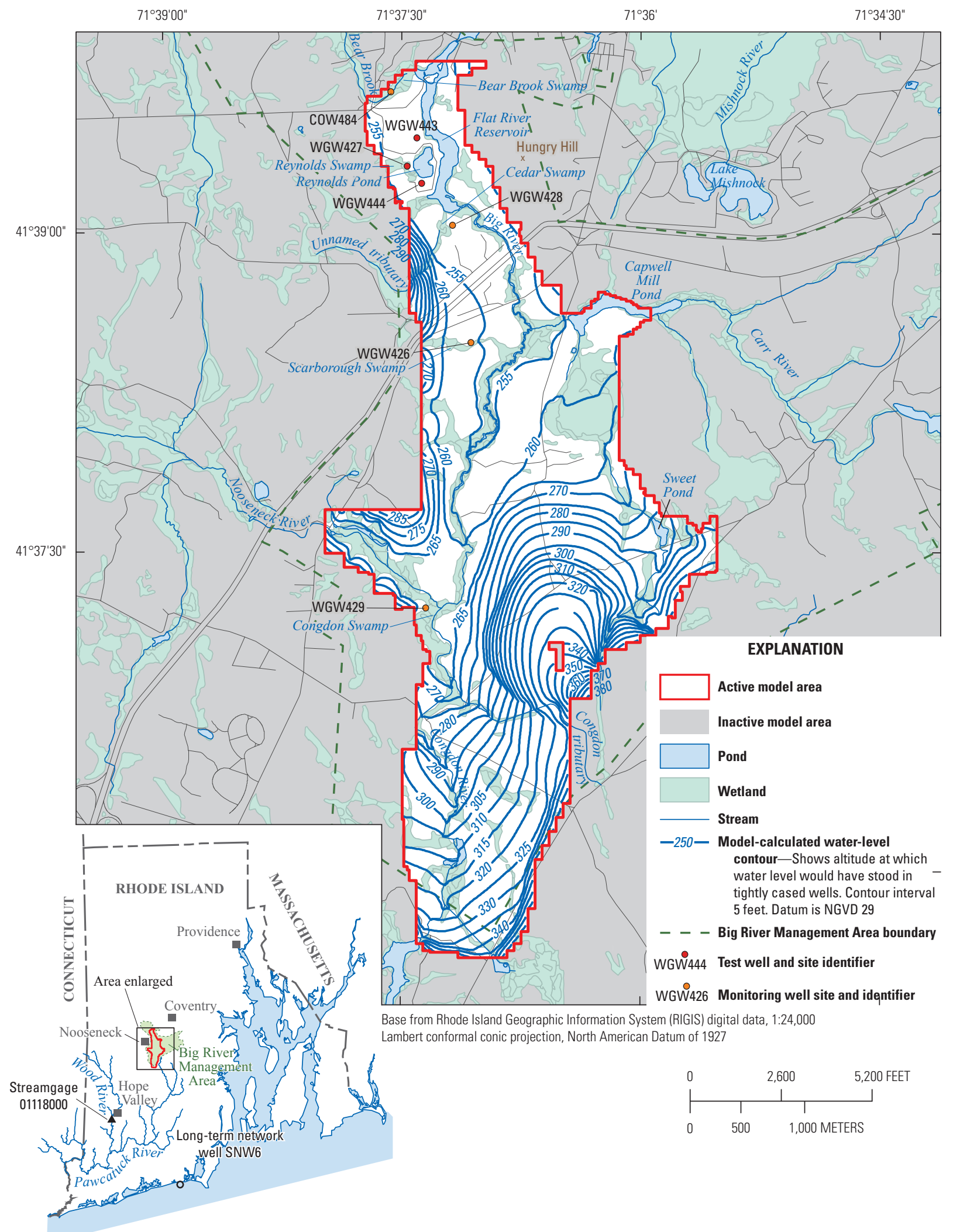

Figure 1. Location of Big River Management Area, central Rhode Island, and model-calculated water levels for long-term average conditions) 
of a conjunctive-management model to determine timevarying monthly groundwater-pumping scenarios that meet groundwater-development goals and instream-flow criteria.

The report by Granato and Barlow (2005) documents a transient-simulation groundwater model coupled with a linear-optimization model to determine the groundwaterwithdrawal patterns that could provide water supplies and sustain streamflows in the BRMA to maintain aquatic and riparian ecosystems; however, the wetlands areas within the BRMA were not explicitly represented in the model, and the potential effects from pumping on these wetland areas were not considered in that analysis.

A need for an assessment of the potential effects of pumping on wetlands in the BRMA led to a cooperative agreement in 2008 between the RIWRB, the U.S. USGS, and the University of Rhode Island (URI). As part of this study, five wetlands areas in the BRMA were instrumented to measure water levels in the streams, at the wetland surface, in wetland sediments, and in the aquifer underlying the wetland areas from 2008 through 2009 to characterize the hydrological connection between surface waters and groundwater under natural conditions in this area (Borenstein and others, 2012).

This report describes the groundwater-flow model development component of this investigation and the analysis conducted to assess the effects of proposed groundwater withdrawals on surface waters, including wetland water levels in the BRMA. The groundwater-flow model used for this analysis was developed as a subregional model of the larger model developed in Granato and others (2003) to focus only on the BRMA and, in particular, on areas that included the proposed well locations in the northern part of the BRMA near an impoundment of the Big River (Flat River Reservoir) (fig. 1).

The results of this study will benefit the development of field and modeling methods to improve the understanding of the effects of pumping on wetlands in stream-dominated, valley-fill aquifers commonly found throughout the glaciated regions of the northeastern United States. The study also provides information about the potential adequacy of shortterm ( 5 days or less) aquifer tests for evaluating long-term effects of groundwater withdrawals on water levels in wetlands; as such, the results of this study may be used to assist in the development of guidelines for assessing potential effects of water-supply development in wetland areas. The study also supports the RIWRB in its mission to develop, protect, conserve, and use the State's water resources while balancing economic development and environmental protection for the State of Rhode Island.

\section{Hydrogeology}

The sand, gravels, silts, and clays that compose the Big River aquifer system were deposited by the advance and retreat of the last two continental ice sheets that covered
New England during the middle and late Pleistocene about 17,000 years ago (Stone and Borns, 1986; Boothroyd and others, 1998; Stone and Dickerman, 2002). These glacial deposits are divided into two broad categories - glacial till and glacial meltwater deposits. Till was deposited directly by glacier ice and is characterized as a nonsorted matrix of sand, silt, and clay with variable amounts of pebbles, cobbles, and large boulders. Glacial meltwater deposits were laid down by meltwater in lakes and streams in front of the retreating ice margin during deglaciation. These materials, also referred to as glacial stratified deposits, consist of wellsorted to poorly sorted layers of gravel, sand, silt, and clay. Postglacial sediments, primarily flood-plain alluvium and swamp deposits, are thin surface units and make up a lesser proportion of the surficial materials in the study area (Stone and Dickerman, 2002).

The aquifer system in the BRMA is unconfined and, for the most part, hydraulically connected with the streams, ponds, and wetlands throughout the area. The sources of water to this aquifer system include precipitation, natural stream and reservoir leakage, and groundwater inflow from adjacent till and bedrock uplands. Recharge from precipitation is estimated in this investigation to average about 27.7 inches per year (in/yr) resulting in about 20 cubic feet per second $\left(\mathrm{ft}^{3} / \mathrm{s}\right) \mathrm{ft}^{3} / \mathrm{s}$ of inflow into the study area. Average monthly rates ranged from 0.08 inches (in.) for July to 4.26 in. for March for the period of 1960 through 2006. Groundwater leaves the aquifer by direct discharge to streams, ponds, and wetlands; by evapotranspiration; and by underflow to adjacent flow systems. Groundwater discharge to surface waters is estimated in this investigation to be about $24 \mathrm{ft}^{3} / \mathrm{s}$ for average annual conditions.

The general direction of groundwater flow in the Big River Valley is eastward from the till and bedrock uplands on the western side of the basin toward the Big River and northward toward the Flat River Reservoir. Groundwater moves through the surficial aquifer in the direction of decreasing water levels. Within the study area, groundwater levels range from a maximum of about 380 feet (ft) above National Geodetic Vertical Datum of 1929 (NVGD 1929) in the southern part of the study area to a minimum of about $245 \mathrm{ft}$ above NVGD 1929 along the Flat River Reservoir (fig. 1). Water-level contours (fig. 1) were calculated for average hydrologic conditions with the model developed for the area in this study and are similar to those drawn on the basis of field measurements and reported in Granato and others (2003). Water-table contours presented in Granato and others (2003) indicate groundwater flow in the Big River Valley is largely independent of flow in the adjacent Carr River and Mishnock River Valleys to the east because of the presence of a northwest-to-southeast-trending bedrock ridge that extends from Hungry Hill towards Capwell Mill Pond and continues southward through the unnamed hill south of the pond (fig. 1).

The largest surface-water feature in the BRMA is the Big River, which drains to the north and is a major tributary 
to the east-flowing Flat River. The primary tributaries to the Big River are the Congdon, Nooseneck, and Carr Rivers and Bear Brook (fig. 1). The Big River flows into the Flat River Reservoir, which is controlled by a dam that maintains the reservoir's water level at an altitude of about $248 \mathrm{ft}$ from March through October and is often lowered by several feet from November through February for the purpose of managing invasive weeds.

A more detailed discussion of the geologic setting and hydrogeologic conditions of the BRMA can be found in Stone and Dickerman (2002) and Granato and others (2003).

\section{Simulation of Groundwater and Surface-Water Interactions}

Groundwater and surface water serve as a single resource that sustains the aquatic habitat of streams, ponds, and wetlands in the valley-fill aquifer systems found throughout the glaciated northeastern United States. Because of the hydraulic connection between groundwater and surface water in the BRMA, there are concerns of potential effects of future groundwater withdrawals on nearby surface waters and wetland vegetation.

Groundwater withdrawals can affect surface-water features in several ways (fig. 2). A pumped well may capture groundwater that would otherwise discharge to wetlands, ponds, and rivers (fig. 2B). Induced infiltration may occur if groundwater withdrawals are large enough and the water level in wetlands and nearby surface-water bodies is greater than the water level in the underlying aquifer (fig. 2C). This can result in wetlands, ponds, and rivers becoming a direct source of water to the pumped well. Regardless of whether groundwater pumping results in captured groundwater or induced infiltration, the amount of water lost from wetlands and nearby surface-water bodies is directly related to the amount of water removed from the aquifer by pumping.

Lowering of water levels may reduce the amount of time that wetlands are inundated and (or) saturated each year (the hydroperiod), potentially causing detrimental impacts to wetland functions and values. Water-level reductions caused by groundwater withdrawals have been shown to increase invasive upland plant species, destructive fires, treefall, soil subsidence, and the disappearance of wetland wildlife swamps and marshes (Rochow and Rhinesmith, 1991; Mortellaro and others, 1995; Skidds and Golet, 2005). Other studies have determined that over time, upland woody vegetation replaces wetland herbaceous vegetation in areas affected by groundwater withdrawals because of changes in the hydroperiod (Sonenshein and Hofstetter, 1990).

A groundwater-flow model was developed as part of this investigation to synthesize the hydrologic data collected at selected wetlands sites (Borenstein and others, 2012) into the context of the surrounding groundwater-flow system to better understand the interaction between surface waters and groundwater in the BRMA. Numerical models were developed previously for this area (Granato and others, 2003; Granato and Barlow, 2005) to assess the effects of proposed minimum streamflow requirements on the maximum amount of allowable pumping. The wetland areas within the BRMA were not explicitly represented in those models because the focus of those studies was on conjunctive management of streamflows to balance water-supply needs and aquatic habitat protection goals; therefore, the potential effects from pumping on these wetland areas were not considered for these analyses.

Renewed interest in the BRMA as a source for groundwater supply has created concerns about the potential effects of pumping on wetlands in the area and initiated
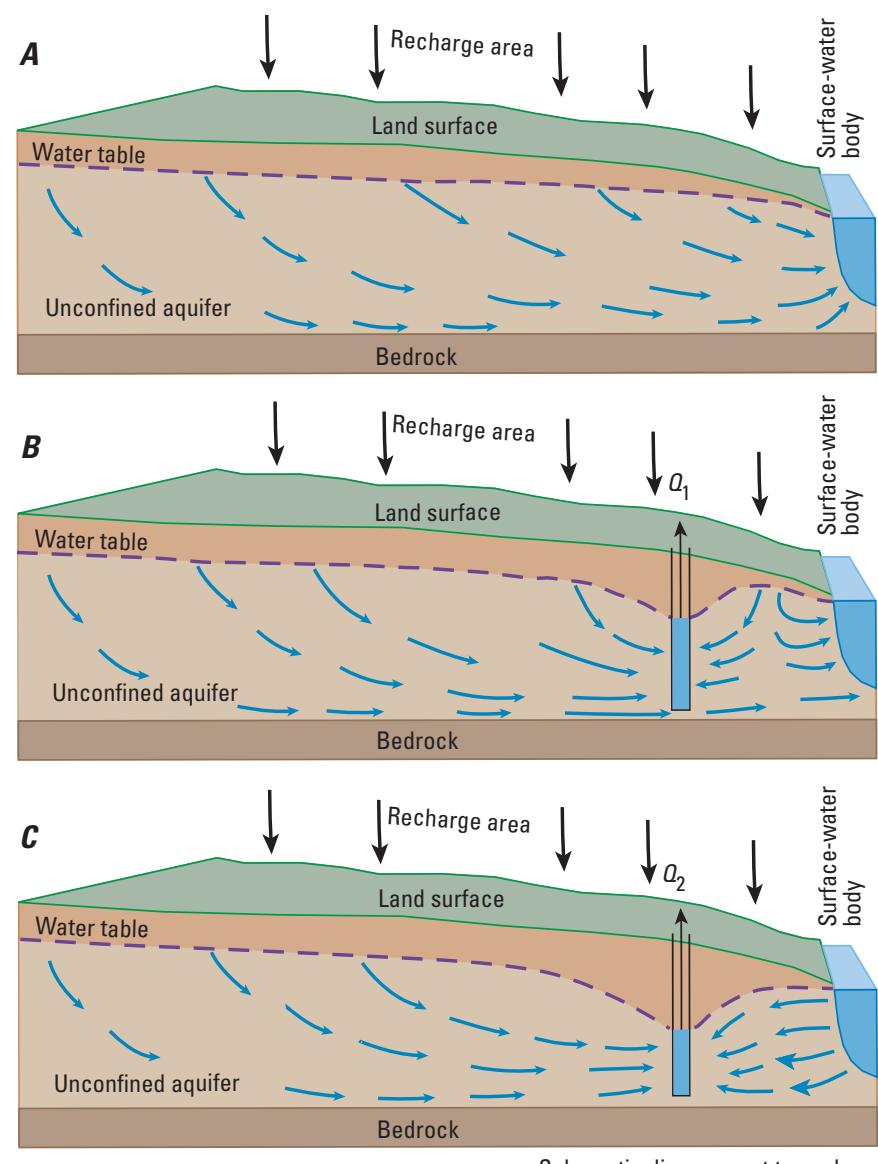

Schematic diagram, not to scale

Figure 2. Schematic diagram of a hypothetical aquifer showing groundwater discharge to a surface-water body with $A$, no pumping; $B$, pumping at a rate (01) such that the well would capture water that otherwise would discharge to the surfacewater body; and $C$, pumping at a higher rate (02) so that the flow direction is reversed and the well pumps water from the surfacewater body. Figure modified from Alley and others, 1999. 
the need for a better understanding of the interaction between groundwater and surface water beneath wetlands. An understanding of this groundwater and surface-water interaction in the BRMA will help water-resources managers and regulatory agencies to meet water-supply demands while minimizing unacceptable effects on natural resources.

\section{Development of the Groundwater Model}

Numerical models provide a means to synthesize existing hydrogeologic information into an internally consistent mathematical representation of a real system or process and thus are useful tools for testing and improving conceptual models or hypotheses of groundwater-flow systems (Konikow and Reilly, 1999). A groundwater-flow model was developed for the BRMA by creating a local-scale model of the previous larger scale model of the BRMA (Granato and others, 2003).

The numerical model developed for this analysis was based on the USGS computer program MODFLOW-2005, which numerically solves the three-dimensional groundwaterflow equation by finite-difference methods (Harbaugh, 2005). The finite-difference grid developed for the modeled area was aligned with the finite-difference grid of the model developed by Granato and others (2003) so that the boundary conditions for the local-scale model could be obtained from the results of the larger-scale model. The purpose of this model was to (1) refine grid spacing to better represent the geometry of surface-water features, (2) use the data collected as part of the previously described field effort (Borenstein and others, 2012 to simulate the groundwater and surface-water interaction at selected wetland sites, and (3) assess potential long-term effects of proposed pumping scenarios on water levels and streamflows in the BRMA.

This local-scale model (fig. 3) was used for steady-state simulations representative of long-term average hydrologic conditions and for transient simulations of dynamic changes in hydrologic conditions in response to time-varying recharge and pumping stresses. The distribution of aquifer characteristics incorporated into the model was derived from available hydrologic data and geologic descriptions (Craft, 2001; Stone and Dickerman, 2002). The model then was calibrated to estimates of groundwater levels and streamflows that are representative of the period of 1960 through 2006.

\section{Model Discretization and Boundary Conditions}

The finite-difference model grid consists of a series of orthogonal model cells in which user-specified hydraulic parameters, model stresses, and boundary conditions are varied spatially. The conceptualization of how and where water enters, moves through, and leaves the aquifer is critical to the development of an accurate flow model (Reilly, 2001). Model inputs include intrinsic aquifer characteristics in each model cell, such as hydraulic conductivity. Boundary conditions are applied at some model cells to simulate hydrologic features, including streams and reservoirs. A detailed discussion of grid discretization, boundary conditions, and the use of finite-difference equations to simulate groundwater flow is presented in McDonald and Harbaugh (1988).

\section{Spatial Discretization}

The total active modeled area of the BRMA system is about $5 \mathrm{mi}^{2}$ (fig. 3). The finite-difference grid for the numerical model consists of 512 rows and 232 columns of uniformly spaced model cells that are $50 \mathrm{ft}$ on each side. The aquifer was subdivided vertically into seven layers of variable thickness that extend from the water table into shallow bedrock to allow for the detail necessary to represent vertical changes in the lithology, proposed pumping well screen zones, and the depth and thickness of streambed and wetland sediments (fig. 4).

\section{Temporal Discretization}

Hydrologic stresses were simulated for average annual and monthly conditions. In these simulations, time is subdivided or discretized into stress periods and time steps. Stress periods refer to periods of time in which specified model stresses, such as pumping and recharge, are constant; changing stresses over time are simulated by using sequential stress periods. Stress periods are further divided into time steps, which are units of time for which water levels and flows are calculated.

Average monthly variations in hydrologic stresses were simulated by dividing the annual hydrologic cycle into 12 monthly stress periods, representing average pumping and recharge rates during each month. Each stress period consisted of daily time steps to increase model stability.

A total of 25 stress periods was simulated for this analysis. The first stress period was specified as steady state, followed by 2 years of monthly stress periods ( 24 stress periods). The water levels produced in the initial steady-state stress period were used as initial conditions for subsequent simulations of monthly stress periods. The 2 years of monthly stress periods were simulated to ensure that enough time had elapsed in the simulation to achieve a state of dynamic equilibrium, defined as a condition in which simulated water levels and flows do not change year to year for a given stress period and time step. The second year of simulated time (stress periods 13 through 25) was used to represent hydrologic conditions over an average year.

\section{Hydrologic Boundary Conditions}

The hydrologic boundaries, or boundary conditions, in the groundwater-flow model are the areas from which, and the method by which, all the water entering and leaving the model is specified.

The upper boundary of the model is the water table, which is a free-surface boundary that receives spatially variable recharge from precipitation. The lower boundary of 


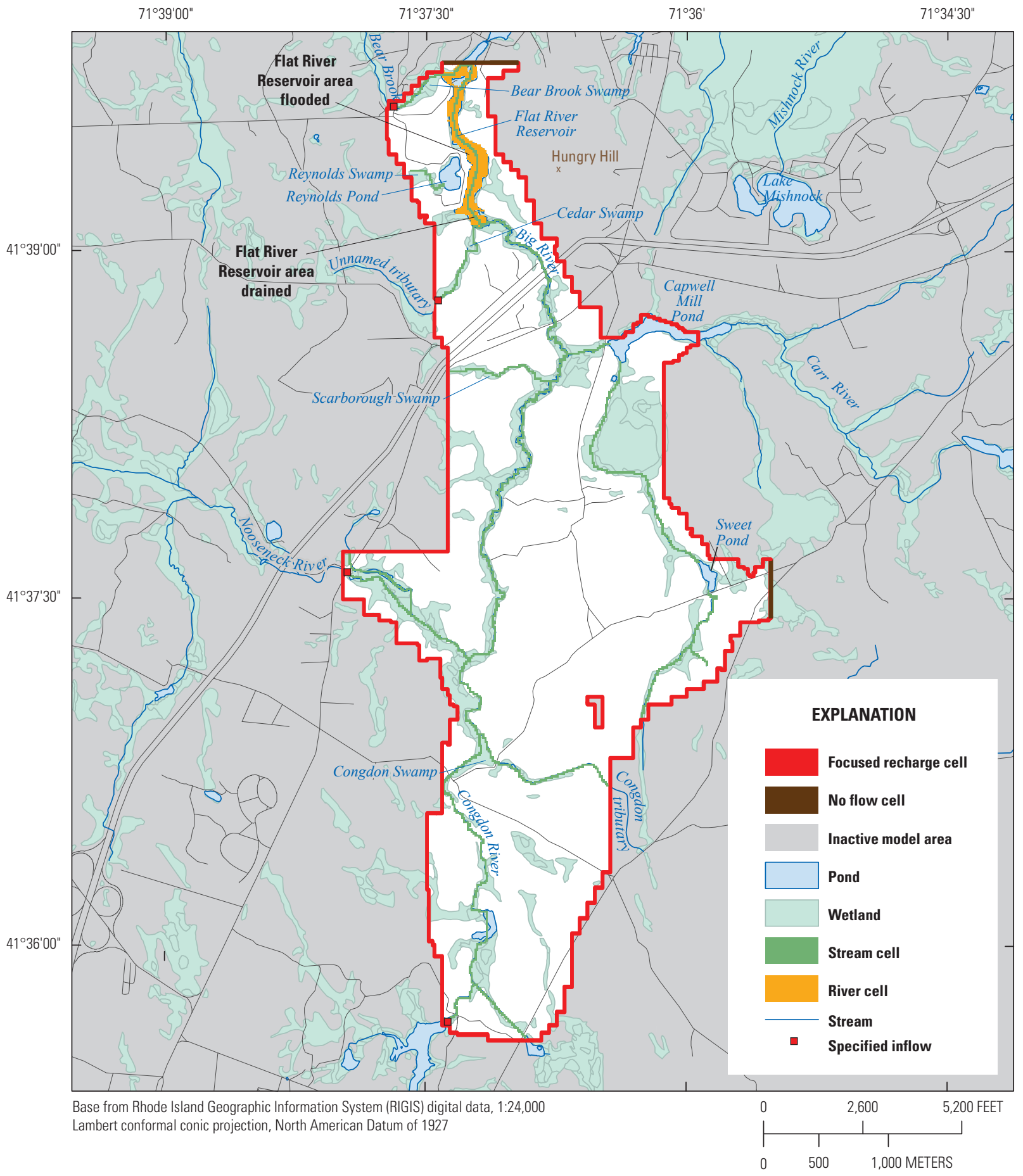

Figure 3. Model extent and distribution of simulated boundary conditions of groundwater-flow model of Big River Management Area, central Rhode Island. 

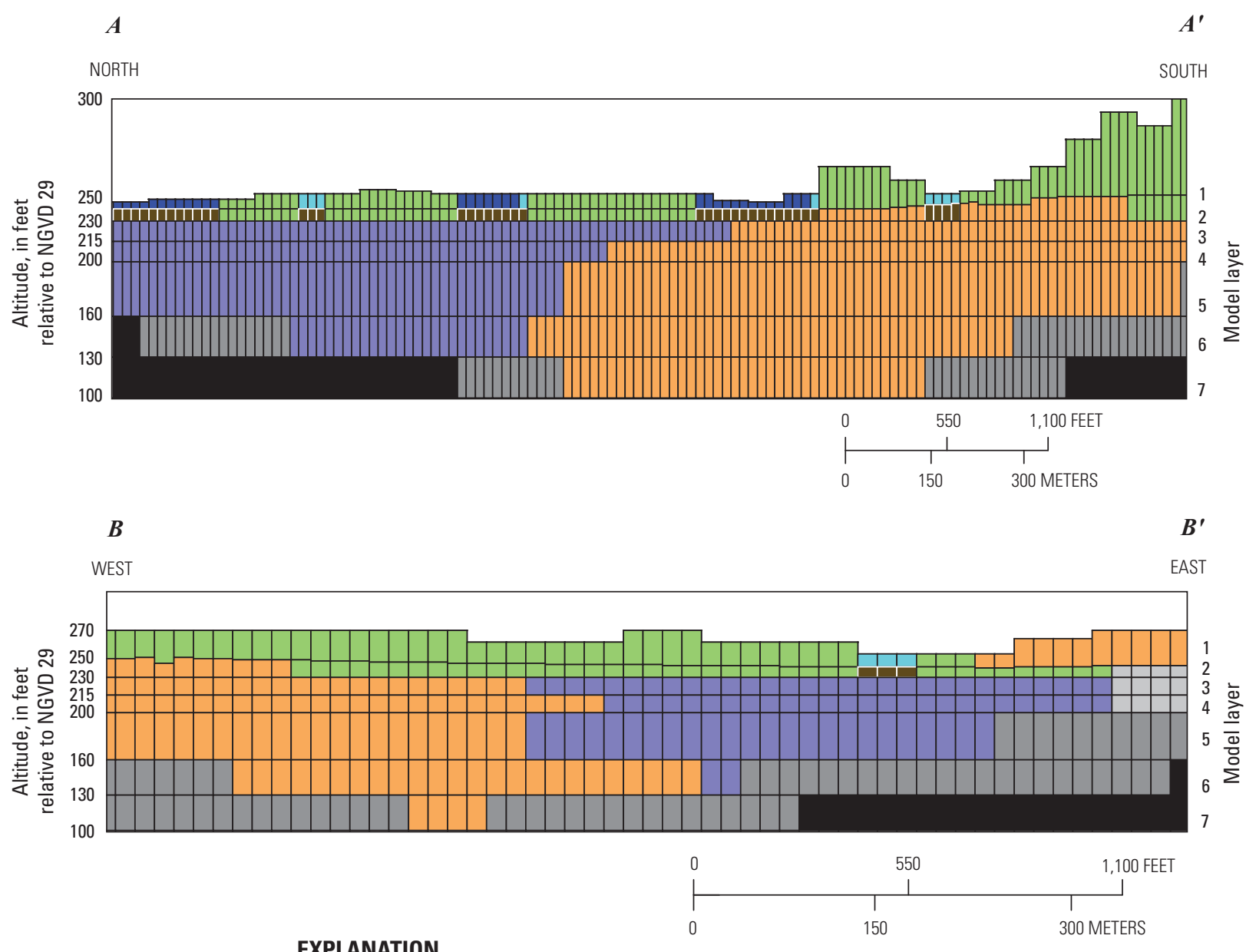

EXPLANATION

Hydrogeologic units

\begin{tabular}{|c|c|c|}
\hline Sand and gravel & Till & Pond \\
\hline Fine/medium sand & Bedrock & Wetland \\
\hline Silt and clay & Peat & Inactive \\
\hline
\end{tabular}

Figure 4. Sections showing vertical layering and model representation of geologic sections $A-A^{\prime}$ and $B-B^{\prime}$. Section lines are shown on figure 6 .

the model is the contact between glacial stratified deposits and the glacial till and bedrock that underlie the entire study area. This boundary was represented as a no-flow boundary condition. The altitude of the bedrock surface ranges from about $340 \mathrm{ft}$ to about $100 \mathrm{ft}$ above NGVD 29 (Stone and Dickerman, 2002).

The lateral boundaries of the model are represented as no-flow boundaries or head-dependent flux boundaries. In this valley-fill aquifer system, the upland till, bedrock, and thinly saturated glacial stratified deposits are represented as no-flow boundaries. The contact between the stratified glacial deposits and till upland areas is simulated as locations of focused recharge to account for the flow from areas outside of the model area that contribute water to the margins of the active area of the model. Recharge rates at these locations were derived from the previous larger scale model of the area (Granato and others, 2003). Part of the eastern boundary also includes a no-flow condition east of Sweet Pond (fig. 1) that represents a groundwater divide in the larger model (Granato and others, 2003).

Specified inflows into the model also include streamflow that enters the active modeled area at five locations along the western boundary of the study area. The five streams are the Congdon River, Nooseneck River, unnamed tributary, the Carr River at the outlet of Capwell Mill Pond, and Bear Brook (fig. 3). The specified flow rates for these five streams were estimated using the "maintenance of variance type 1 (MOVE.1) method (described in the appendix) with USGS streamgage data as originally reported in Granato and others (2003). 
Flow leaves the aquifer system at the northern (downgradient) extent of the active model area at the Flat River Reservoir, which was simulated in the model by a combination of head-dependent flux boundaries including the MODFLOW River (RIV), Drain (DRN), and Streamflow Routing (SFR2) packages (McDonald and Harbaugh, 1988; Niswonger and Prudic, 2005). In this area, the downstream part of the Big River drains into the Flat River Reservoir (fig. 1). The reservoir stage is manually controlled by a sluiceway where releases are made periodically to drain the reservoir for the management of invasive weeds. These releases typically occur in late fall through early winter to expose weeds to the open air during cold months. During this period of lower reservoir stage, the remaining area of open water in the upper portion of the reservoir above Harkney Hill Road is reduced to only the stream channel that runs through the center of the once flooded area (fig. 5A).

Representation in the groundwater model of the manipulation of reservoir stage and the resulting change in the flooded area were accomplished by simulating the flooded area from March through October using the RIV package, and the drained or exposed area from November through February using the DRN package. When the reservoir stage is high from March through October (fig. 5B), the RIV package is used to simulate the open water of the reservoir at a constant stage that will be unaffected by groundwater pumping. The use of the RIV package is based on the assumption that an "infinite" supply of water potentially could be available to the aquifer and to wells pumping from the aquifer given the pumping rates assumed for this investigation compared to the volume of the reservoir and amount of flow entering from the Big River (50 $\mathrm{ft}^{3} / \mathrm{s}$ on an average basis); this assumption appears reasonable.

When the reservoir stage is lowered from November through February, the DRN package replaced the RIV package to simulate groundwater discharge at seepage faces along the exposed pond-bottom sediments that occurs when the lower reservoir stage exposes these pond-bottom sediments to open air (fig. 5A). The DRN package assumes the same hydraulic conductance or leakance term as the RIV package; however, because the DRN package only allows water to flow from the aquifer to the simulated stream, the DRN package prevents this area from becoming a source of water to the aquifer or nearby pumping wells. The stage in DRN package was lowered from $248 \mathrm{ft}$ to $245 \mathrm{ft}$ above NGVD 1929 to represent the change in the reservoir stage.

In addition to the RIV and DRN packages, the SFR2 package was used to simulate flow from the Big River to the reservoir and through the reservoir area when the reservoir is drained. This boundary condition was applied to model cells down the centerline of the reservoir (fig. 3), and this boundary was active throughout the simulation period.

The SFR2 boundary condition also was used to simulate the remaining rivers present in the active modeled area. The SFR2 package allows for groundwater discharge to streams (gaining stream reaches) as well as streamflow seepage into the aquifer (losing stream reaches). The use of the SFR2 package to represent streams allows for the simulation of losing conditions downgradient from pond outlets or near pumping wells, but unlike the RIV package, the SFR2 package will not allow surface-water features to become infinite sources of water to the aquifer after the water level falls below the specified streambed bottom (Niswonger and Prudic, 2005).

The groundwater model simulates discharge to the streams for average conditions and, as a result, will underpredict peak streamflow conditions resulting from overland runoff. Most streams in the aquifer are gaining; however, losing conditions can develop adjacent to upland areas, downstream from pond outlets, and near pumping wells. The SFR2 package also accounts for water that is routed through stream networks. This routing capability is used in the models to route water from pond outlets into receiving streams.

The simulated discharge at head-dependent boundaries is a function of the hydraulic conductance, which represents resistance to flow across the streambed from fine-grained sediments. The hydraulic conductance was calculated for each model cell containing a stream as

$$
C=\frac{(K)(W)(L)}{(M)},
$$

where

$$
\begin{aligned}
& \text { C is hydraulic conductance of the streambed, in } \\
& \text { square feet per day; } \\
& K \quad \text { is vertical hydraulic conductivity of streambed } \\
& \text { deposits, in feet per day; } \\
& W \quad \text { is the width of the streambed within the model } \\
& \text { cell, in feet; } \\
& L \quad \text { is the length of the streambed within the } \\
& \text { model cell, in feet; and } \\
& M \quad \text { is the thickness of the streambed, in feet. }
\end{aligned}
$$

The simulated vertical hydraulic conductivity of the streambed deposits $(K)$ was 30 feet per day $(\mathrm{ft} / \mathrm{d})$; it was assumed that the permeability of the streambed is similar to that of the surrounding aquifer. A width $(W)$ of $10 \mathrm{ft}$, a thickness $(M)$ of $5 \mathrm{ft}$, and a length $(L)$ of $50 \mathrm{ft}$ were assumed for all the streams simulated in the flow model. Streambed altitudes represented in the model were estimated from the digital elevation data for the study area described previously in Granato and others (2003).

A previous analysis in a similar hydrogeologic setting in coastal Rhode Island (Masterson and others, 2007) determined that large changes in simulated hydraulic conductance and streambed altitudes can affect the location and amount of groundwater discharge to surface-water bodies. However, obtaining the information necessary to measure these properties throughout the study area would require a larger and more detailed hydrologic data-collection effort than was possible for this analysis.

Ponds in the Big River aquifer system are assumed to be generally in direct hydraulic connection with the aquifer 
A

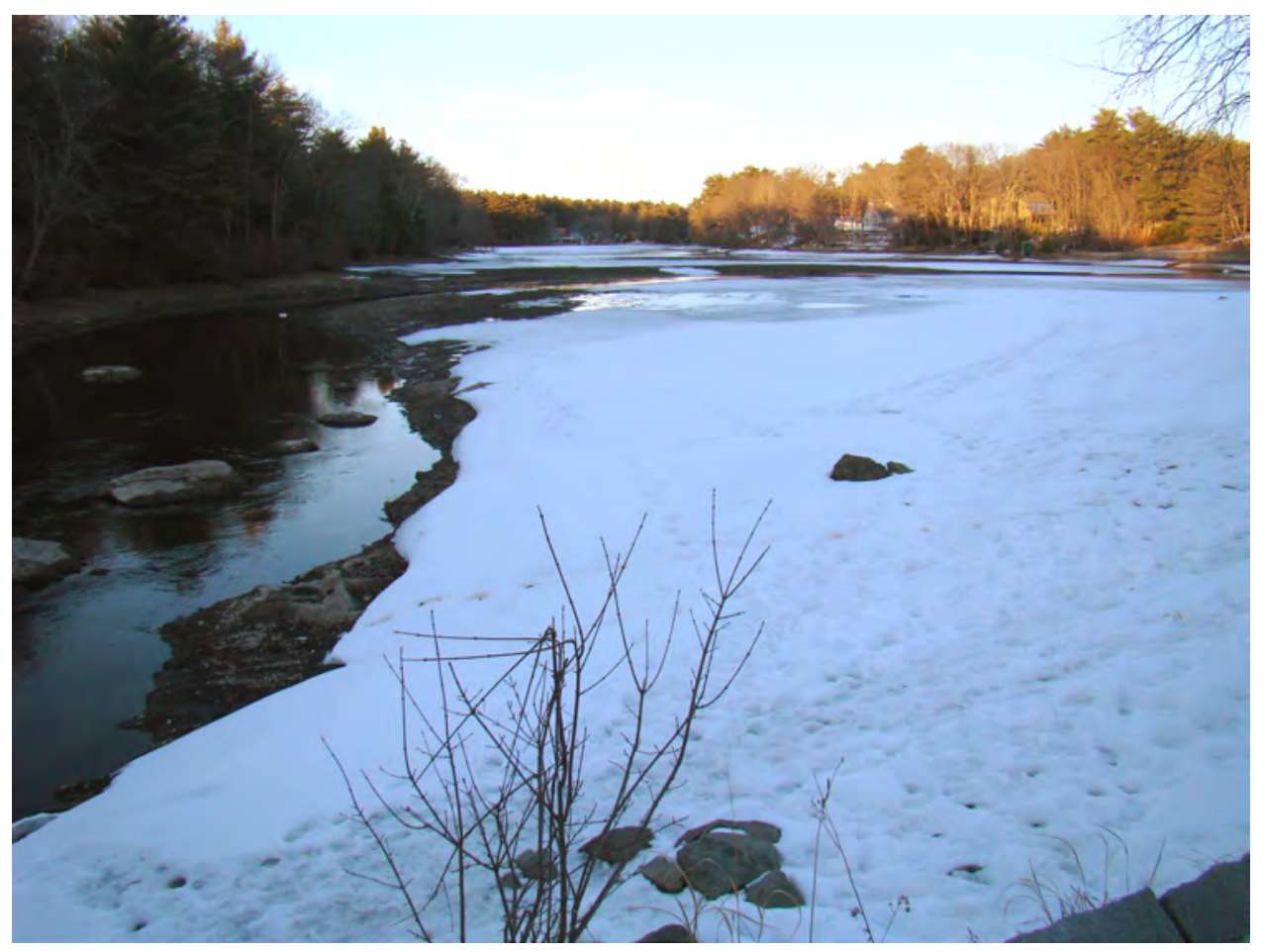

$\boldsymbol{B}$

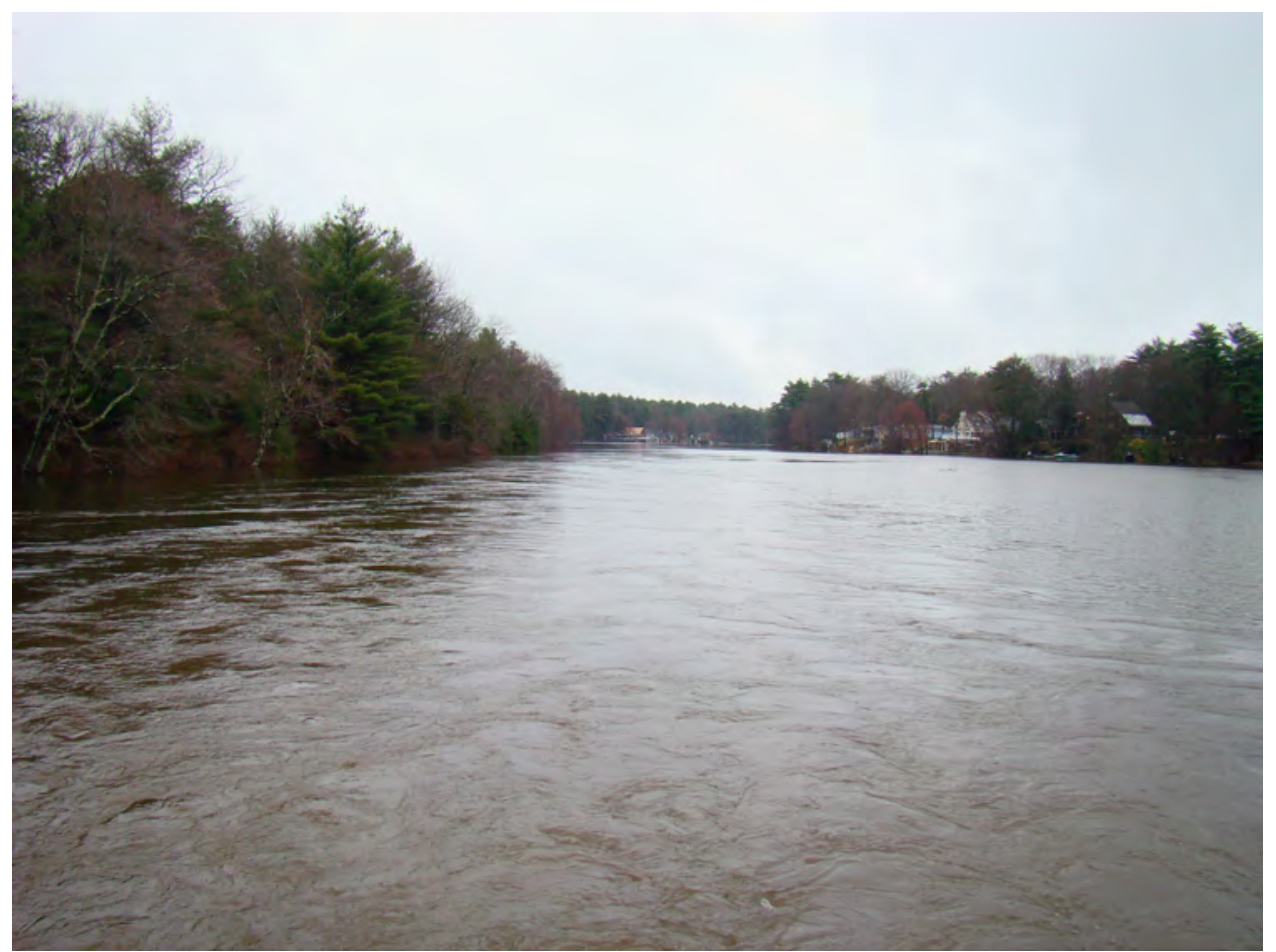

Figure 5. Big River at Harkney Hill Road, Coventry, Rhode Island A, conditions in the river in February 2010 when the stage in the Flat River Reservoir was relatively low and streamflow was limited to the channel of the river. $B$, conditions in March 2010 when the stage of the reservoir was relatively high and the river overflowed its channel. 
and are regions of the aquifer with no effective resistance to flow. As a result, groundwater-flow lines converge towards ponds in upgradient areas, where water discharges to ponds, and diverge in downgradient areas, where ponds recharge the aquifer. In the models, ponds are simulated as areas of high horizontal hydraulic conductivity $(5,000 \mathrm{ft} / \mathrm{d})$, more than an order of magnitude higher than the horizontal hydraulic conductivity values simulated in the surrounding aquifer. This difference in horizontal hydraulic conductivity causes preferential flow through the pond and simulates the observed effects that ponds have on groundwater flow in the aquifer system.

Wetlands were simulated in the top model layer as areas of high horizontal hydraulic conductivity $(1,000 \mathrm{ft} / \mathrm{d})$ to account for the effects of standing water on hydraulic gradients in wetlands. The underlying wetland peat deposits were represented as areas of low hydraulic conductivity in layer 2.

\section{Hydraulic Properties}

The water-transmitting properties of the aquifer sediments, as represented by horizontal hydraulic conductivity $(K)$ and vertical anisotropy, are functions of lithology and differ according to grain size and the degree of sorting of the sediments. The four major hydrogeologic units in the study area are glacial stratified deposits, glacial till, wetlands' peat, and bedrock. The surficial geology of the study area is shown on figure 6 .

The stratified glacial deposits are composed of gravel, sand, silt, and clay that were carried away from the glacial ice front by meltwater streams. Thick, coarse-grained, stratified sediments that consist of highly transmissive fine sand to coarse gravel have the capacity to yield large quantities of water to wells and form the principal (or surficial) aquifer in the study area. General trends in the geologic framework include thick deposits of glaciolacustrine sediments beneath the Flat River Reservoir part of the BRMA overlying more permeable sands and gravels. These fine-grained deposits were not present in the southern part of the study area where the aquifer decreases in thickness (fig. 7A).

The relation between lithology and aquifer characteristics (horizontal hydraulic conductivity and vertical anisotropy) was based on reviews of hydrogeologic information from previous investigations in the BRMA (Craft, 2001; Stone and Dickerman, 2002; Granato and others, 2003). Previous hydrogeologic investigations in southern Rhode Island (Friesz and Stone, 2007; Masterson and others, 2007; Friesz, 2010; Masterson, 2011) also were used to better understand the relation between lithology and aquifer characteristics in the study area.

Horizontal hydraulic conductivity values from these previous investigations ranged from 70 to $350 \mathrm{ft} / \mathrm{d}$ for fine to coarse sands and gravel to 10 to $30 \mathrm{ft} / \mathrm{d}$ for fine sand and silt (table 1). These estimates of hydraulic properties values were distributed throughout the model domain based on the hydrogeologic framework developed by Stone and Dickerman (2002) and the results of aquifer tests conducted in the northern part of the study area in the late 1990s (Craft, 2001; Stone and Dickerman, 2002), and more recently (December 2009) as part of ongoing groundwater-resources investigations in the area (Blake Martin, Weston and Sampson, Inc, written commun., 2010). The largest difference in horizontal hydraulic conductivity values between the current and previous model (Granato and others, 2003) is the representation of wetland hydraulic properties and the thick glaciolacustrine deposits that underlie the northern part of the study area near the Flat River Reservoir (fig. 7A,B). The hydraulic properties of the wetland peat deposits were obtained from sediment core analyses from selected wetlands in the study area (Borenstein and others, 2012).

Vertical anisotropy (VA), which is the ratio of horizontal to vertical hydraulic conductivity, generally increases with decreasing horizontal hydraulic conductivity; anisotropy values for glacial sediments range from about 3:1 for sand and gravel to 100:1 for silt and clay (Granato and others, 2003; Masterson and others, 2007; Masterson, 2011). The values of VA and the corresponding range in $K$ used in the calibrated model are presented in table 1.

For transient simulations, a uniform specific-yield value of 0.25 was used for the uppermost active layers, and a uniform storage coefficient value of $1 \times 10^{-5}$ was used for the lower confined layers. These values were based on the values used in the previous model (Granato and others, 2003) and were consistent with previous investigations in similar hydrogeologic settings (Friesz and Stone, 2007; Masterson and others, 2007; Masterson and others, 2009). In the model cells representing ponds, the specific yield was set to a value of 1.0 to account for the high storage capacity assumed for the ponds. All of the surface-water features in the study area were represented in the top layer of the model.

\section{Hydrologic Stresses}

The hydrologic stresses simulated in the model include recharge from precipitation, reservoir-stage management, and the proposed groundwater withdrawal scenarios developed as part of the ongoing water resources investigation. Currently, there are no large-capacity groundwater withdrawals in the BRMA.

\section{Recharge}

The primary source of water to the BRMA aquifer is recharge derived from precipitation. Precipitation at T.F. Green Airport Weather Station in Providence, R.I., has averaged $48 \mathrm{in} / \mathrm{yr}$ from 1960 through 2006 (National Oceanic and Atmospheric Administration, 2007). Some precipitation is lost to evapotranspiration and overland runoff to streams; the remainder recharges the aquifer at the water table or on the surface of ponds and wetlands. Therefore, the simulated recharge to the groundwater system consists of three separate 


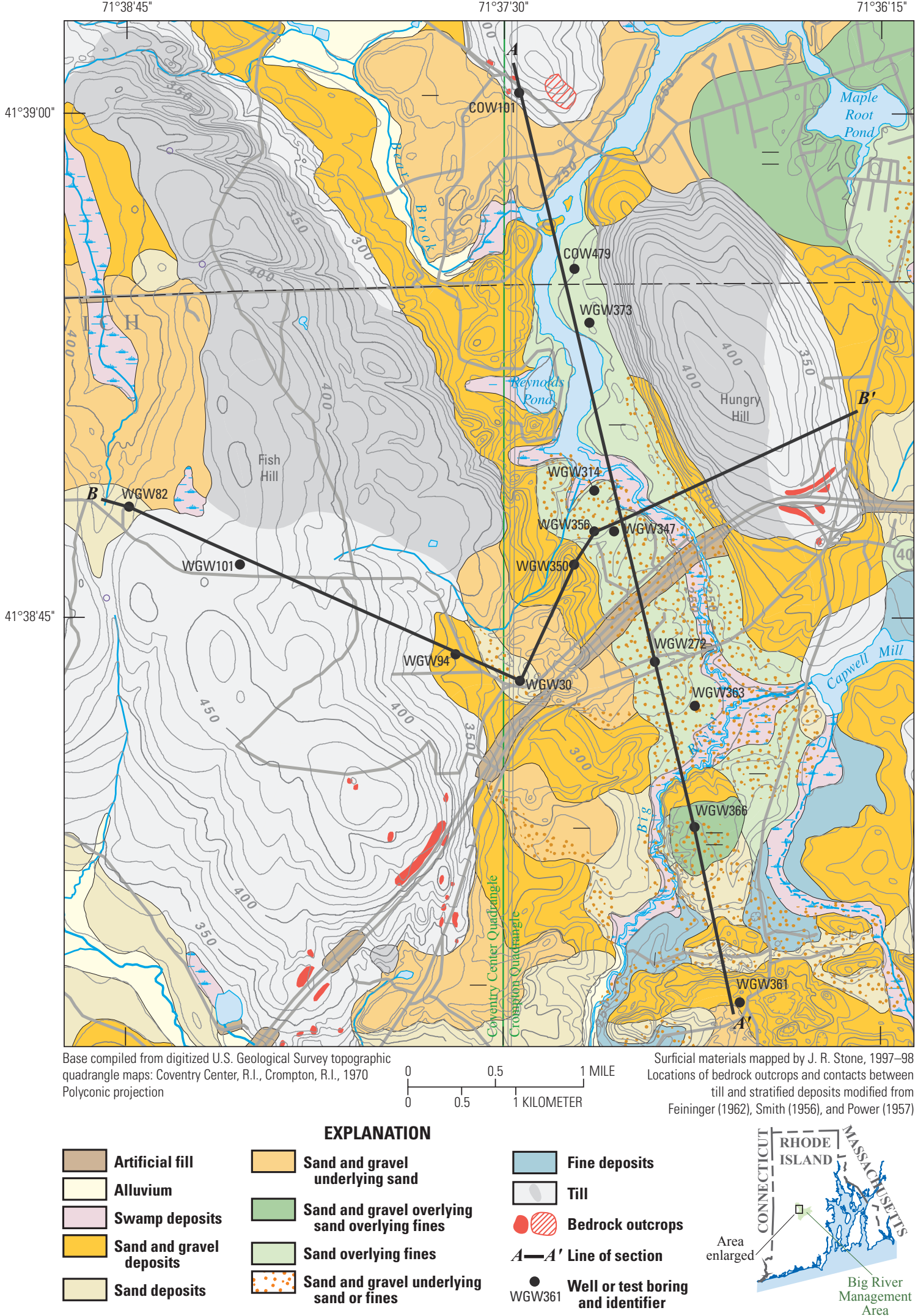

Figure 6. Surficial geology of the Big River Management Area, central Rhode Island (modified from Stone and Dickerman, 2002) 

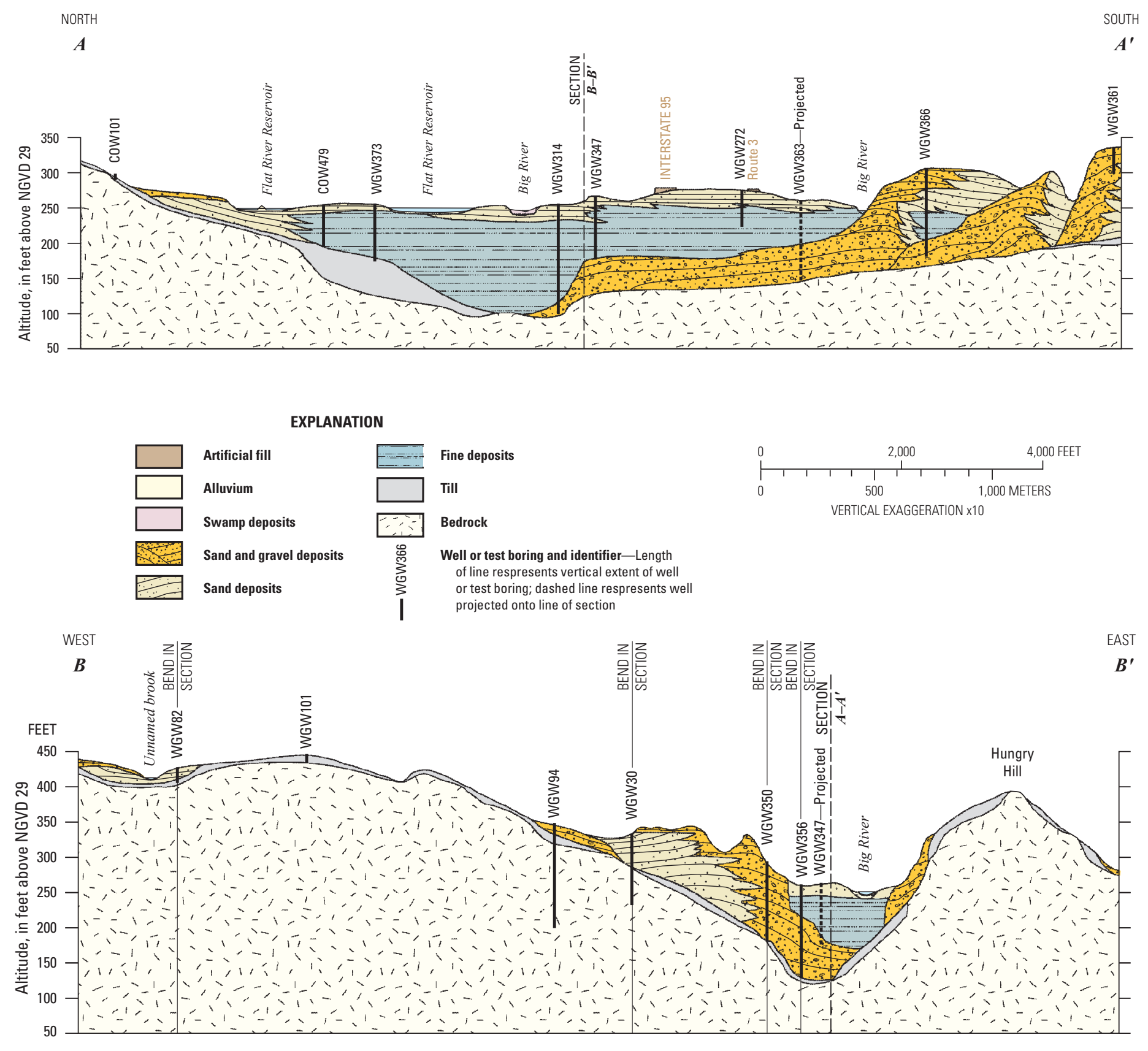

EXPLANATION

\begin{tabular}{|c|c|}
\hline & Artificial fill \\
\hline & Alluvium \\
\hline & Swamp deposits \\
\hline$\because$ & Sand and gravel deposits \\
\hline$\Longrightarrow$ & Sand deposits \\
\hline
\end{tabular}

Fine deposits
Bedrock

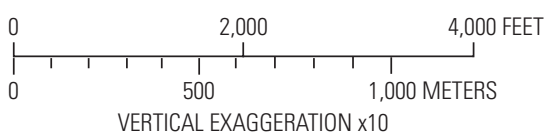

Figure 7. Geologic sections $\left(A-A^{\prime}\right.$ and $\left.B-B^{\prime}\right)$ showing the distribution of stratified glacial deposits in the Big River Management Area, central Rhode Island (modified from Stone and Dickerman, 2002; NGVD 29. 
Table 1. Horizontal hydraulic conductivity and horizontal to vertical anisotropy values of the lithologic units used in the groundwater-flow model of the Big River Management Area, central Rhode Island.

\begin{tabular}{lll}
\hline Lithologic deposit & $\begin{array}{c}\text { Horizontal } \\
\text { hydraulic } \\
\text { conductivity } \\
\text { (feet per day) }\end{array}$ & $\begin{array}{c}\text { Horizontal to } \\
\text { vertical } \\
\text { anisotropy }\end{array}$ \\
\hline $\begin{array}{c}\text { Stratified glacial deposits } \\
\quad \text { Sand and gravel }\end{array}$ & $250-350$ & $3: 1$ to $5: 1$ \\
$\quad$ Fine/medium sand & $70-125$ & $10: 1$ to $30: 1$ \\
$\quad$ Fine sand and silt & $10-30$ & $30: 1$ to $100: 1$ \\
$\quad$ Silt and clay & $0.1-10$ & $100: 1$ to $1: 1$ \\
Peat & 0.1 & $1000: 1$ \\
Till & $1-5$ & $10: 1$ \\
Bedrock & 0.01 & $1: 1$ \\
\hline
\end{tabular}

components: (1) areal recharge to land surface overlying stratified glacial deposits, (2) recharge to land surface overlying upland till deposits, and (3) recharge to open-water bodies and wetlands.

An average annual recharge rate of $27.7 \mathrm{in} / \mathrm{yr}$ was calculated by the climatic water-budget computer program WATBUG (Wilmott, 1977). WATBUG uses the Thornthwaite method (Chow, 1964) to compute climatic water budgets on a daily or monthly time scale based on daily temperature and precipitation data from the Providence weather station from 1960 through 2006 and an estimate of soil-moisture capacity. Required data input for WATBUG include the latitude of the weather station, measured daily temperature and precipitation values, and an estimate of ambient soil-moisture capacity. Output values include actual and potential evapotranspiration rates and the change in soil-moisture storage (water available for recharge). The soil-moisture capacity (moisture retained in the soil after excess moisture is drained through gravity drainage) was assumed to be $6 \mathrm{in} / \mathrm{yr}$ based on the previous work of Carlson and Lyford (2005).

Average monthly recharge rates from 1960 through 2006 for the stratified glacial deposits ranged from a low of $0.08 \mathrm{in}$. for July to a high of $4.26 \mathrm{in}$. for March with an average of 2.3 inches per month (in/mo) (fig. 8). The variation in monthly recharge rates is the result of changes in monthly precipitation and evapotranspiration rates. Evapotranspiration rates increase over the summer and early fall months; as a consequence, a greater percentage of precipitation that occurs during these months is lost to evapotranspiration compared to the winter and spring months, resulting in a reduced amount of recharge to the aquifer in the summer and fall months.

Inflow to the modeled area from the surrounding upland till areas (fig. 6) was based on the same spatial distribution of inflow from the analysis of Granato and others (2003). The method for apportioning this inflow was based on seasonal patterns of streamflow in a till-dominated environment. In the previous study, this inflow was simulated as a specified flux by use of injection wells along the contact between the upland till and adjacent stratified glacial deposits, whereas in this investigation the inflow was simulated as specified recharge in these areas. This method resulted in the same amount of inflow entering the active model area while helping avoid numerical instability issues with the model simulations. Overall, the total recharge from the upland till areas was similar to the glacial stratified deposits; however, the timing of this recharge differed over the year because of differences in topography and aquifer storage and hydraulic conductivity properties of the till sediments (Granato and others, 2003).

Surface-water bodies such as ponds and wetlands were determined to be, on an annual basis, areas of net recharge to the aquifer. The simulated recharge for ponds was determined by the free-water-surface potential evaporation rate calculated by the Jensen-Haise method (Jensen and Haise, 1963). This method uses air-temperature and solar-radiation data to estimate free-water-surface evaporation obtained from the weather station at T.F. Green Airport, Providence, R.I.

The estimated free-water-surface potential evaporation rate was determined to be $28 \mathrm{in} / \mathrm{yr}$, similar to the rate determined by Farnsworth and others (1982) for the northeastern United States, resulting in a net recharge rate of $20 \mathrm{in} / \mathrm{yr}$ for ponds for average annual conditions from 1960 through 2006. Average monthly recharge rates for the ponds varied from a low of -2.08 in. for July to a high of 4.07 in. for March with an average of about $1.7 \mathrm{in} / \mathrm{month}$ (fig. 8). Negative recharge rates calculated for the summer months indicate that the estimated free-water-surface potential evaporation rate is higher than the average monthly precipitation rate for those months resulting in a lowering in pond levels from increased evaporation.

In wetlands, evapotranspiration is assumed to account for a substantial loss of water, which can be as large, or larger, than the evaporation loss from ponds because of the combined effect of evaporation and transpiration in these flooded, vegetated areas. Therefore, a uniform recharge rate of about $8.4 \mathrm{in} / \mathrm{yr}$ was specified for all the wetlands in the study area, which is about 40 percent of the recharge rate specified for ponds and about 30 percent of the rate for the surrounding aquifer. This value was based on previous analyses in the New England wetland systems (Hemond, 1980; Zarriello and Bent, 2004). Average monthly recharge rates from 1960 through 2006 for the wetlands varied from a low of -8.12 in. for July to a high of $4.58 \mathrm{in}$. for December with an average of about $0.7 \mathrm{in} /$ month (fig. 8 ).

It should be noted, however, that recharge in wetlands can vary greatly depending on the extent of open water, amount and type of vegetation, location of the wetland in the flow system, and whether the wetlands have surface-water outflows (Masterson and others, 2009). Negative recharge rates calculated for the summer months indicate that the estimated evapotranspiration rate is higher than the average monthly precipitation rate for those months resulting in a lowering of water levels in wetlands. 


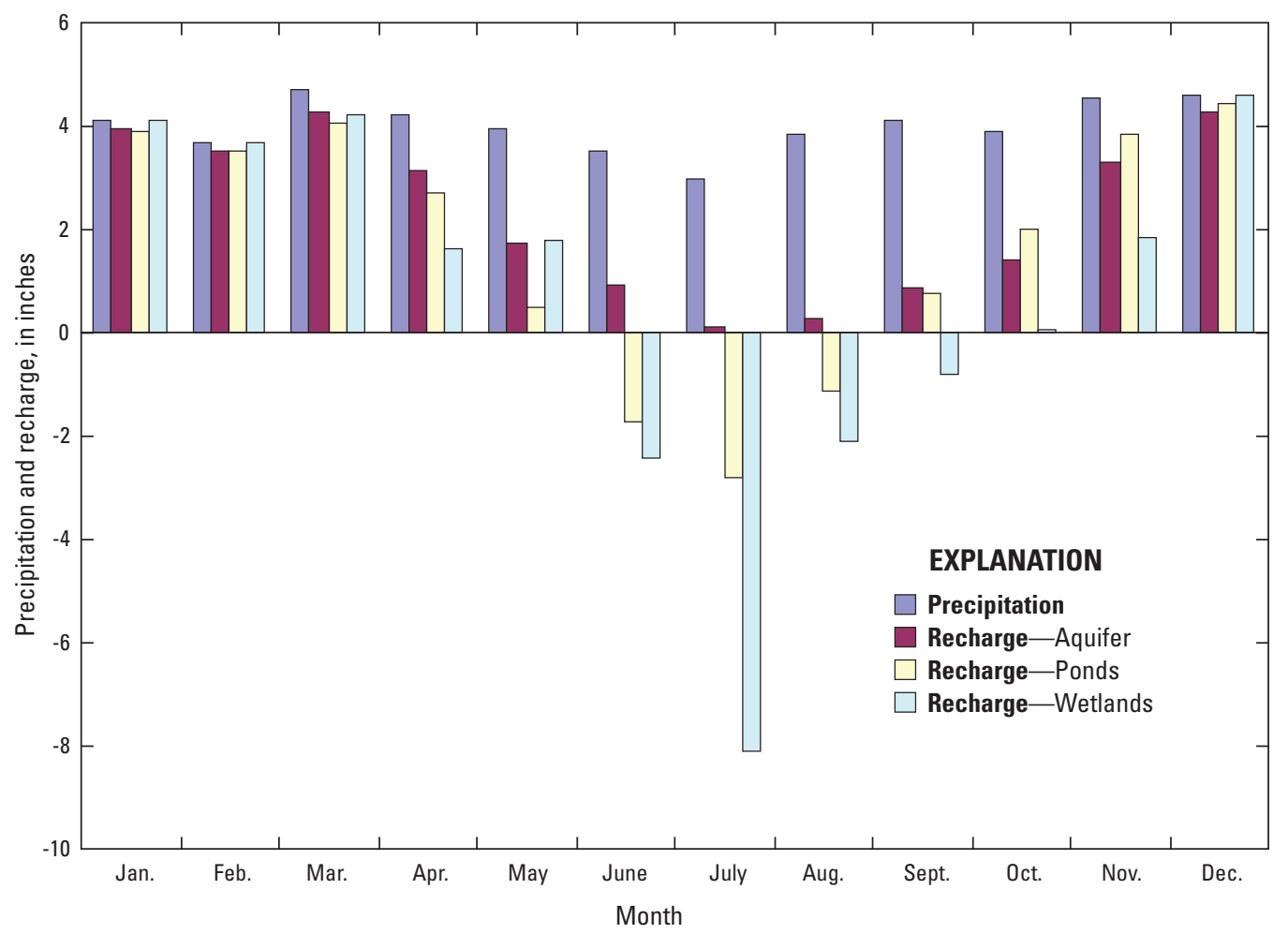

Figure 8. Monthly values of precipitation and calculated aquifer recharge at the T.F. Green Airport weather station, Providence, Rhode Island, from 1960 through 2006.

\section{Pumping}

Currently, there are no groundwater withdrawals in BRMA; however, plans have been proposed to withdraw as much as 7.0 million gallons per day (Mgal/d) from this area in the future (Granato and Barlow, 2005). Recently, waterresources investigations conducted by the RIWRB (Blake Martin, Weston and Sampson, Inc., written commun., 2009) have identified two test sites (WGW443 and WGW444; fig.1) and conducted an aquifer test from December 16 to 21,2009, at rates of 550 gallons per minute (gal/min) and $490 \mathrm{gal} / \mathrm{min}$ at WGW443 and WGW444, respectively. These pumping wells were simulated by the MODFLOW Well (WEL) package (McDonald and Harbaugh, 1988), which is a specified-flux boundary condition. Pumping rates were simulated for the 5-day period of the aquifer test to provide additional modelcalibration data. These pumping rates also were simulated for long-term average conditions to assess the long-term effect of pumping on water levels and streamflows in the BRMA.

\section{Model Calibration}

Model calibration is the process by which modifications are made to the initial model-input parameters for the purpose of making the model output more closely match measured water levels and streamflows (Reilly and Harbaugh, 2004). Because numerical models synthesize existing hydrogeologic information into an internally consistent mathematical representation of a real system, the numerical representation is a much simpler, generalized representation of the real system. Hydraulic properties are represented in the model as parameter values assigned to multiple cells within a region of the model.

For this analysis, calibration was achieved for this analysis through trial-and-error manipulation of model input parameters within reasonable limits and comparing the resulting model-calculated long-term hydraulic heads and flows to measured and estimated values. These calibration targets included estimates of long-term average monthly water levels and streamflows (fig. 9) from 1960 through 2006, along with the water levels measured during the aquifer test conducted in December 2009 (Blake Martin, Weston and Sampson, Inc., written commun., 2010).

The estimates of long-term average monthly water levels and streamflows were based on the MOVE. 1 regression method with USGS index-station data. Regression equations for groundwater-level data were calculated manually and regression equations for streamflow data were calculated with the Streamflow Record Extension Facilitator program (Granato, 2009). The equations were developed by assessing correlations between data from the index sites with data from each site of interest, graphing the data to assess the regressionmodel fit, and using monthly statistics from the long-term index sites to estimate values at the site of interest. A more detailed description of the MOVE.1 method can be found in appendix 1. 


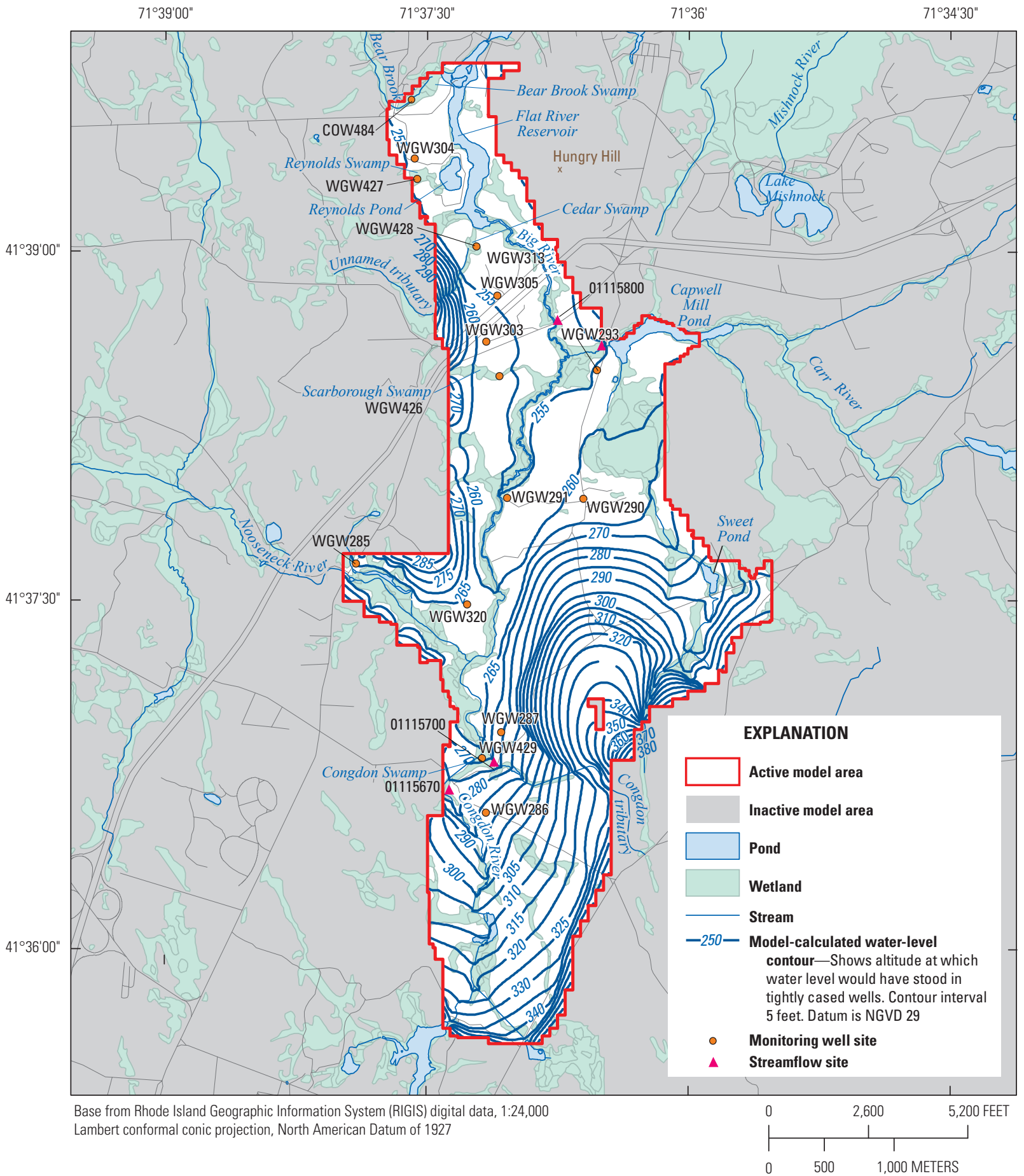

Figure 9. Locations of water-level and streamflow sites used for model calibration and model-calculated water-level contours for long-term average conditions, Big River Management Area, central Rhode Island. 
The comparison between model-calculated and the estimated water levels for long-term average conditions included a determination of the mean of the residuals (the difference between estimated and model-calculated water levels) and the absolute mean of the residuals. Ideally, the mean of the residuals will be randomly distributed and close to zero, indicating no bias in the results, and the mean of the absolute residuals will be less than 5 percent of the total range in head for the water-level measurements used for model calibration (Anderson and Woessner, 1992). The absolute mean of the residual for the monthly average conditions was $1.31 \mathrm{ft}$. These values correspond to about 3.4 percent of the total range (38 ft) in measured (estimated) water levels for the study area and indicate the model-calculated water levels were in reasonable agreement with the estimated data.

The mean of the residuals (estimated minus model calculated) for the long-term average conditions and average monthly conditions was $0.05 \mathrm{ft}$, indicating that the residuals have a near random distribution around zero. Comparisons of model-calculated and estimated water levels (fig. 10A) and of the residual water levels as a function of the estimated water levels (fig. 10B) illustrate the model provides a reasonable match to estimated water levels for long-term average conditions and the residuals generally are unbiased throughout the range of estimated water levels in the aquifer system (fig. 10B).

In addition to using the mean of the residuals and the absolute mean of the residuals as metrics for determining the goodness of fit between estimated and model-calculated water levels, simulated changes in monthly water levels were compared to estimated average monthly measurements in long-term monitoring wells to assess the capacity of the model to predict the effects of changing stresses on the hydrologic system. The model-calculated values are, for the most part, in agreement with the estimated average monthly water levels calculated by MOVE.1, indicating that the model provides a reasonable representation of monthly changes in water levels in this analysis (fig. 11), especially in the northern part of the study area near the proposed water-supply sites (fig. 9).

The estimated and model-calculated water levels did not match well in the southeastern part of the study area (fig. 9) near wells WGW285-287 and WGW320 (fig. 11A-C, K). Possible explanations for the difference between modelcalculated and estimated water levels in this area include (1) the influence of simulated changes in monthly flows in the nearby streams, (2) the specified inflows along the eastern boundary in this area of the model, or (3) the inadequate representation of the hydrogeologic framework in the southeastern part of the study area.

Another measure of how well the model matched the estimated water levels was to assess the match of changes in vertical gradient at the wetland sites that were instrumented to measure water levels above and below the wetland peat materials. The three sites selected were the Reynolds Pond Swamp (WGW427), Cedar Swamp (WGW428), and Scarborough Swamp (WGW426) (fig. 1). A comparison of the change in vertical gradients (head difference between the surface water and the deep well) indicates an acceptable agreement between the model-calculated and estimated water levels (fig. 12) with the exception of the Cedar Swamp site (fig. 12B).

The estimated changes in vertical gradient at Cedar Swamp indicate a near constant upward gradient of about $0.2 \mathrm{ft}$ throughout the year compared to the model-calculated range in upward gradients of 0.3 to $0.6 \mathrm{ft}$, with the highest rates occurring in late winter and spring when simulated recharge rates are high. The difference between estimated and model-calculated vertical gradients may be the result of a local-scale hydrogeologic feature specific to Cedar Swamp that is not adequately represented in the flow model, such as the permeability of the underlying peat sediment. Local variations in the permeability of the peat layer separating the shallow, flooded part of Cedar Swamp from the underlying aquifer system can affect the hydrologic gradient estimated between the shallow (WGW429) and deeper (WGW431) wells that would not be accounted for in the flow model given the lack of hydrogeologic data available on changes in permeability of the peat sediments.

The MOVE. 1 analysis also was used to estimate longterm average monthly streamflow values from 1960 through 2006. Data from the long-term streamgage 01118000 on the Wood River at Hope Valley in the nearby Pawcatuck River Basin were selected to represent long-term conditions in the BRMA because correlations among streamflow measurements in these areas are very strong (greater than 0.91; see appendix table 1-2). This streamgage has a long, uninterrupted period of record that includes 1960-2006, and water use in the Wood River Basin is a small percentage of average monthly streamflows (Masterson and others, 2009). A comparison of model-calculated and estimated streamflows indicates that the model-calculated streamflows generally are in agreement with estimated long-term average conditions at the USGS streamgages (fig. 13) with the exception of the unnamed tributary to the Congdon River in the southern part of the study area (fig. 13C), which may be a result of the explanations described previously for the differences in the match between estimated and model-calculated water levels in this area.

\section{Simulation of Groundwater Withdrawals}

Previous studies in the BRMA were designed to assess the effects of pumping on streamflow; changes in water levels in the aquifer and in wetlands were not considered (Granato and others, 2003; Granato and Barlow, 2005). As part of the previous studies, several possible well sites were identified for withdrawals of as much as $7.0 \mathrm{Mgal} / \mathrm{d}$ of groundwater; however, this proposed pumping scenario required multiple well sites to limit pumping during summer months when streamflows are typically at their lowest flows in any given year. 

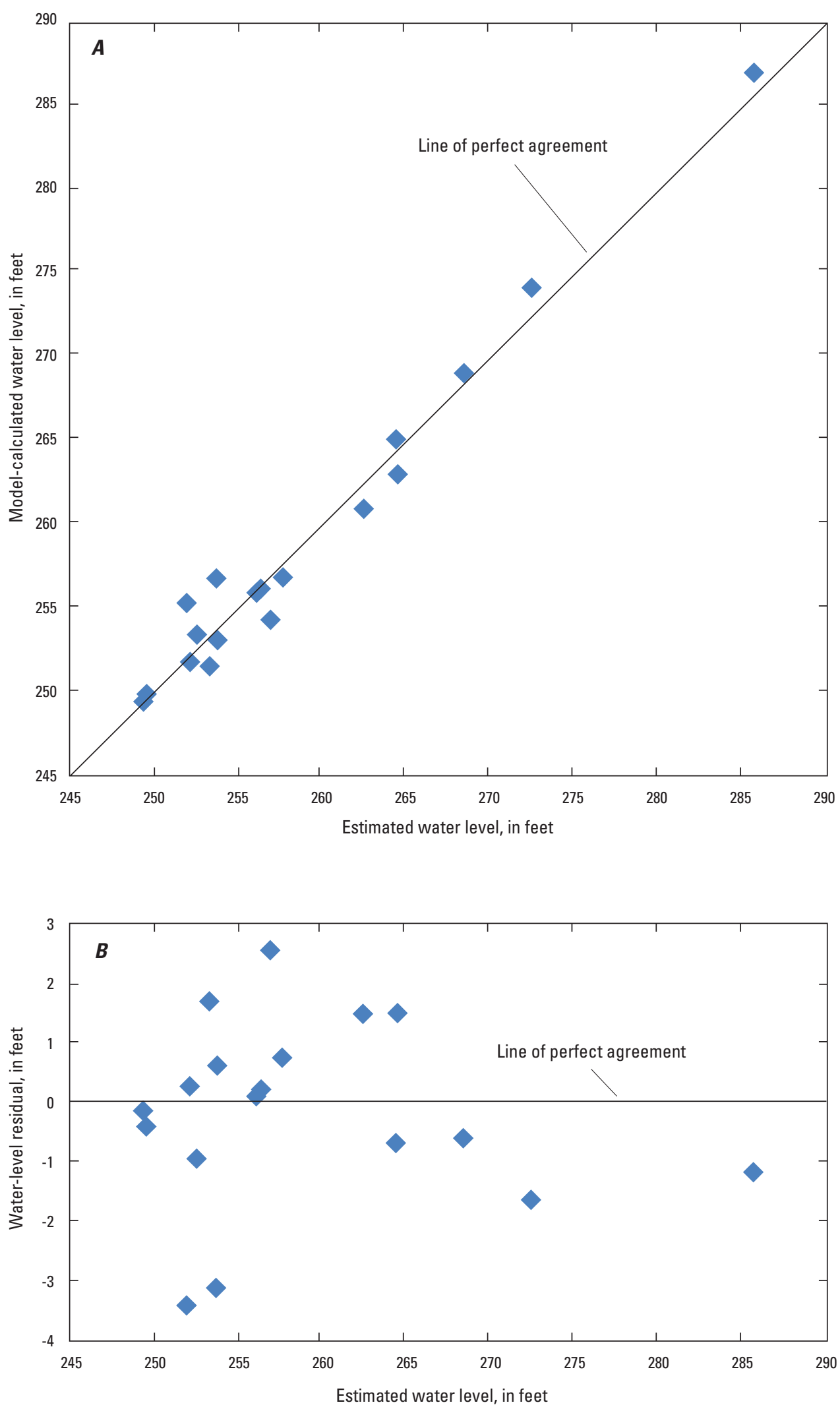

Figure 10. Comparison of $A$, model-calculated and estimated water levels, and $B$, residual (estimated minus model calculated) water levels as a function of estimated water levels for long-term average conditions. 


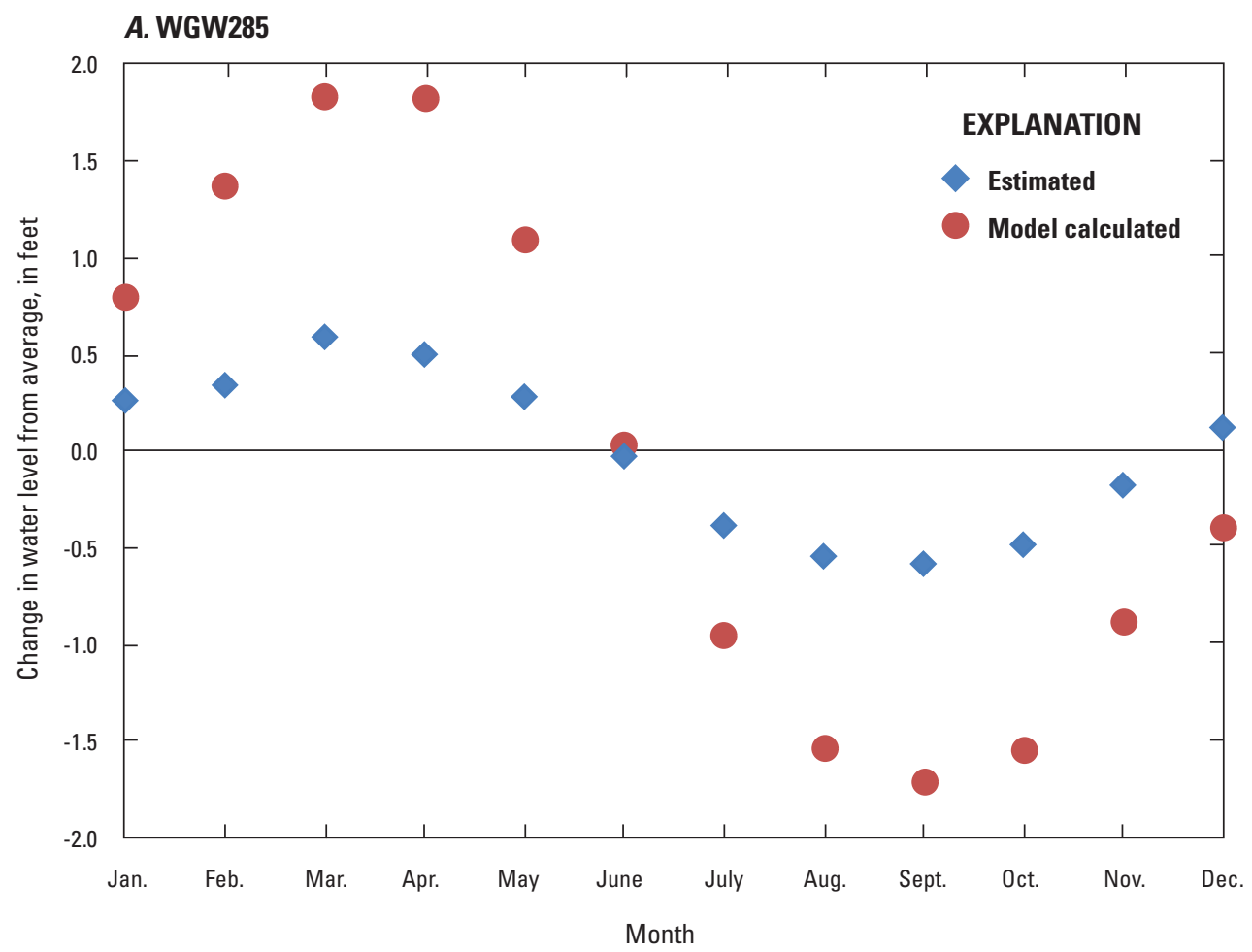

\section{B. WGW286}

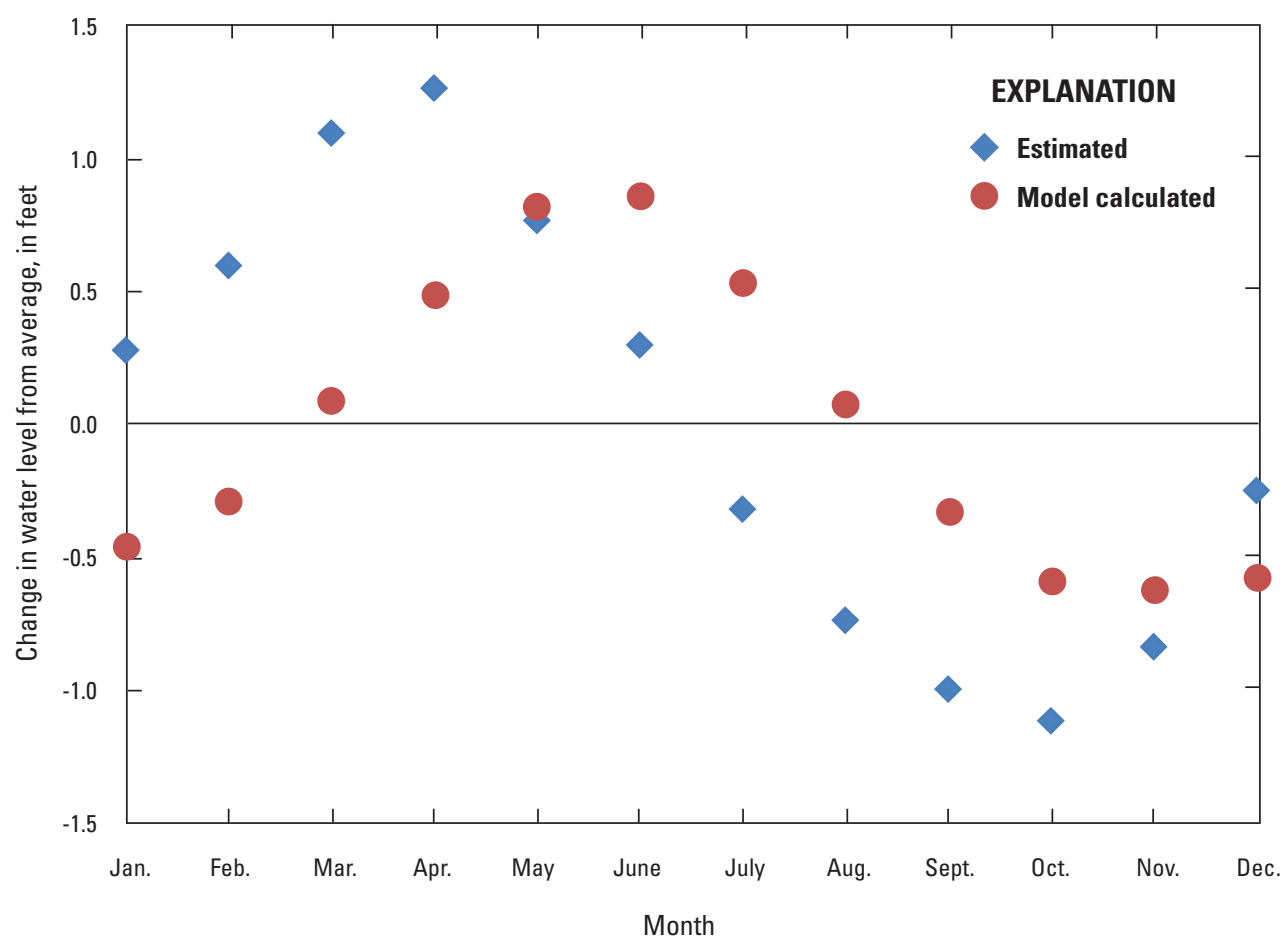

Figure 11. Comparison of monthly departure from average conditions for model-calculated and estimated water levels for observation wells $A$, WGW285; $B$, WGW286; $C$, WGW 287;

D, WGW 290; E, WGW291; F, WGW293; G, WGW303; H, WGW304; I, WGW305; J, WGW313; and

$K$, WGW320 in the Big River Management Area, central Rhode Island. 


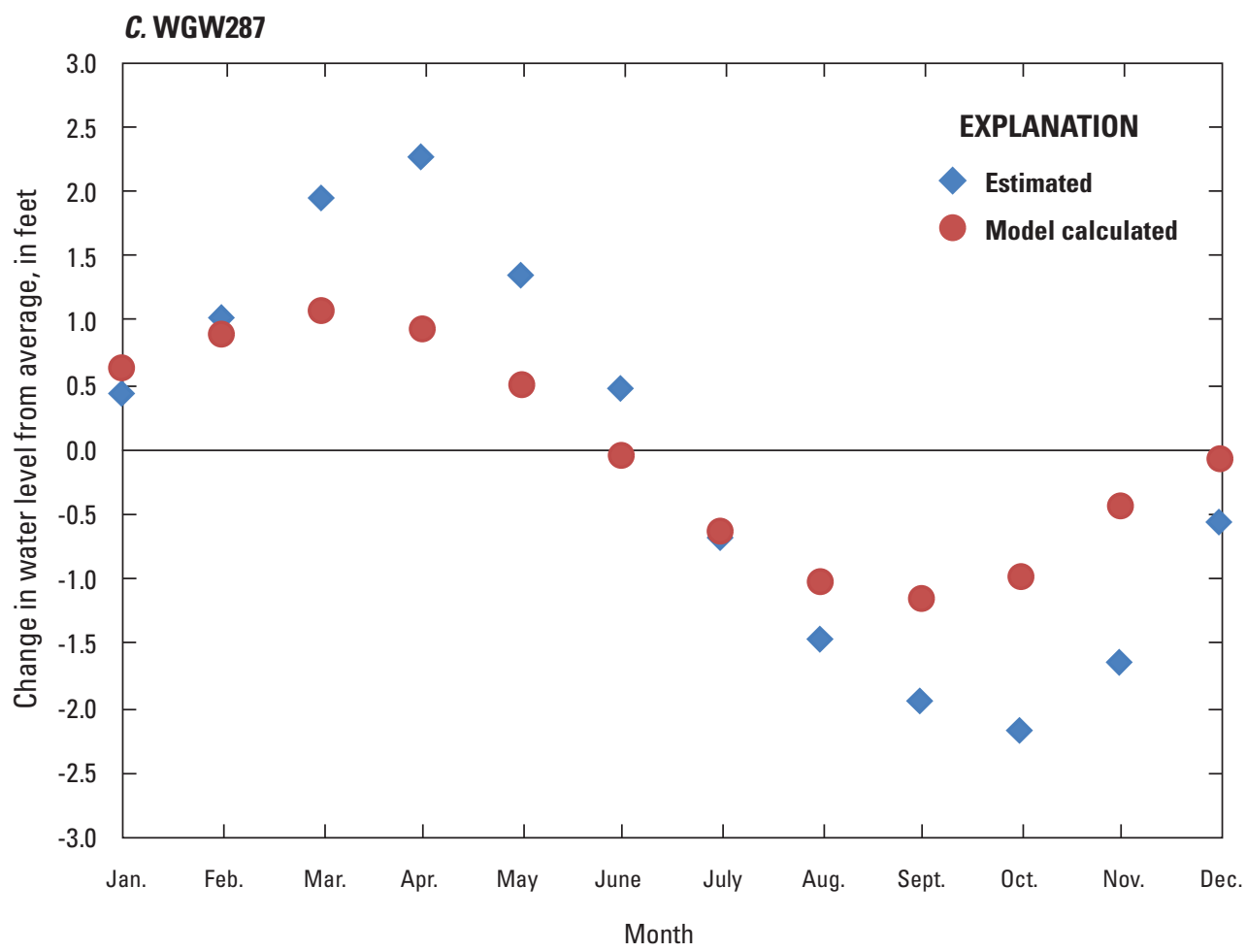

\section{WGW290}

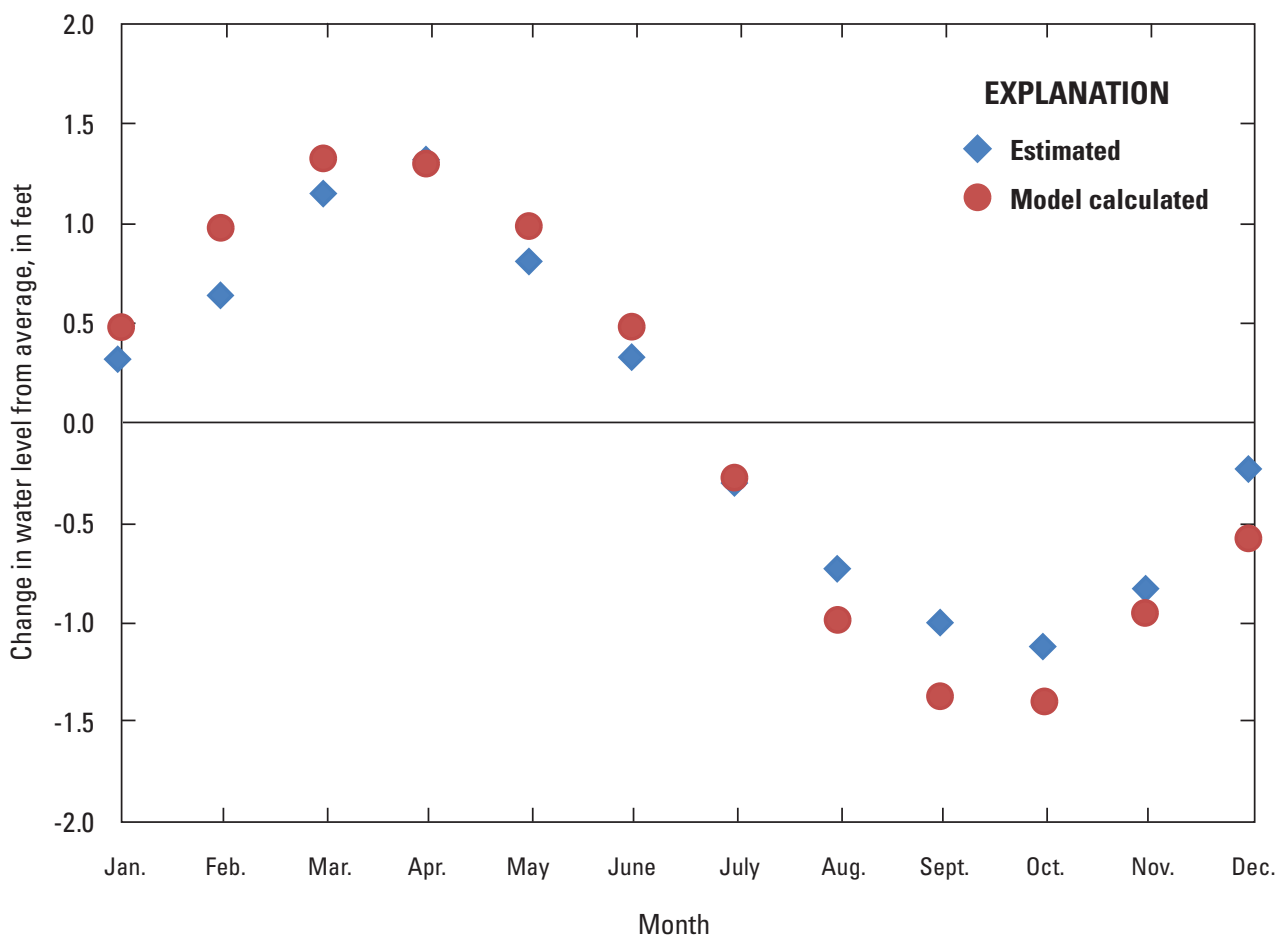

Figure 11. Comparison of monthly departure from average conditions for model-calculated and estimated water levels for observation wells $A$, WGW285; $B$, WGW286; $C$, WGW 287; $D$, WGW 290; E, WGW291; F, WGW293; G, WGW303; H, WGW304; I, WGW305; J, WGW313; and K, WGW320 in the Big River Management Area, central Rhode Island. 

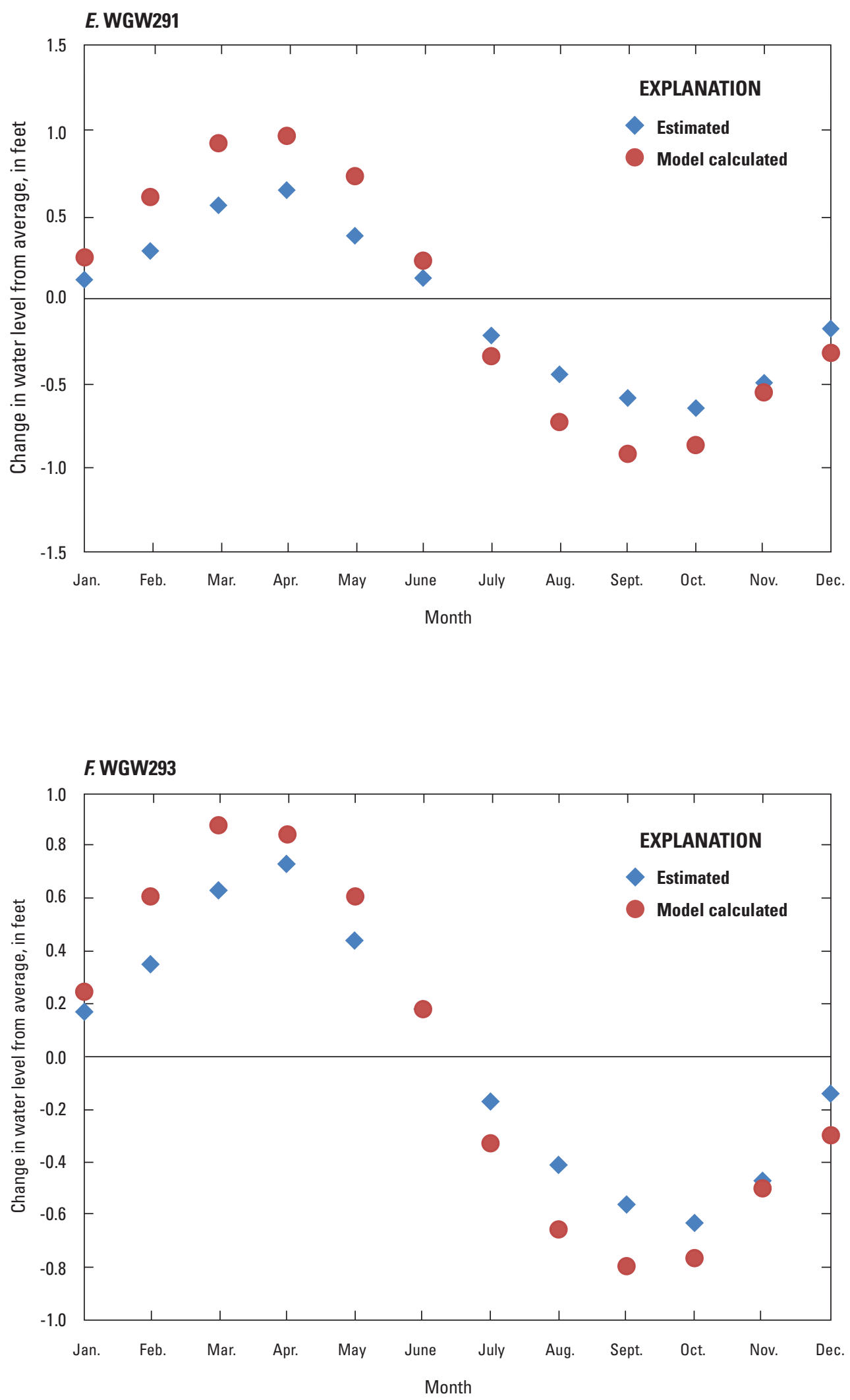

Figure 11. Comparison of monthly departure from average conditions for model-calculated and estimated water levels for observation wells $A$, WGW285; $B$, WGW286; $C$, WGW 287; $D$, WGW 290; E, WGW291; F, WGW293; G, WGW303; H, WGW304; I, WGW305; J, WGW313; and K, WGW320 in the Big River Management Area, central Rhode Island. 


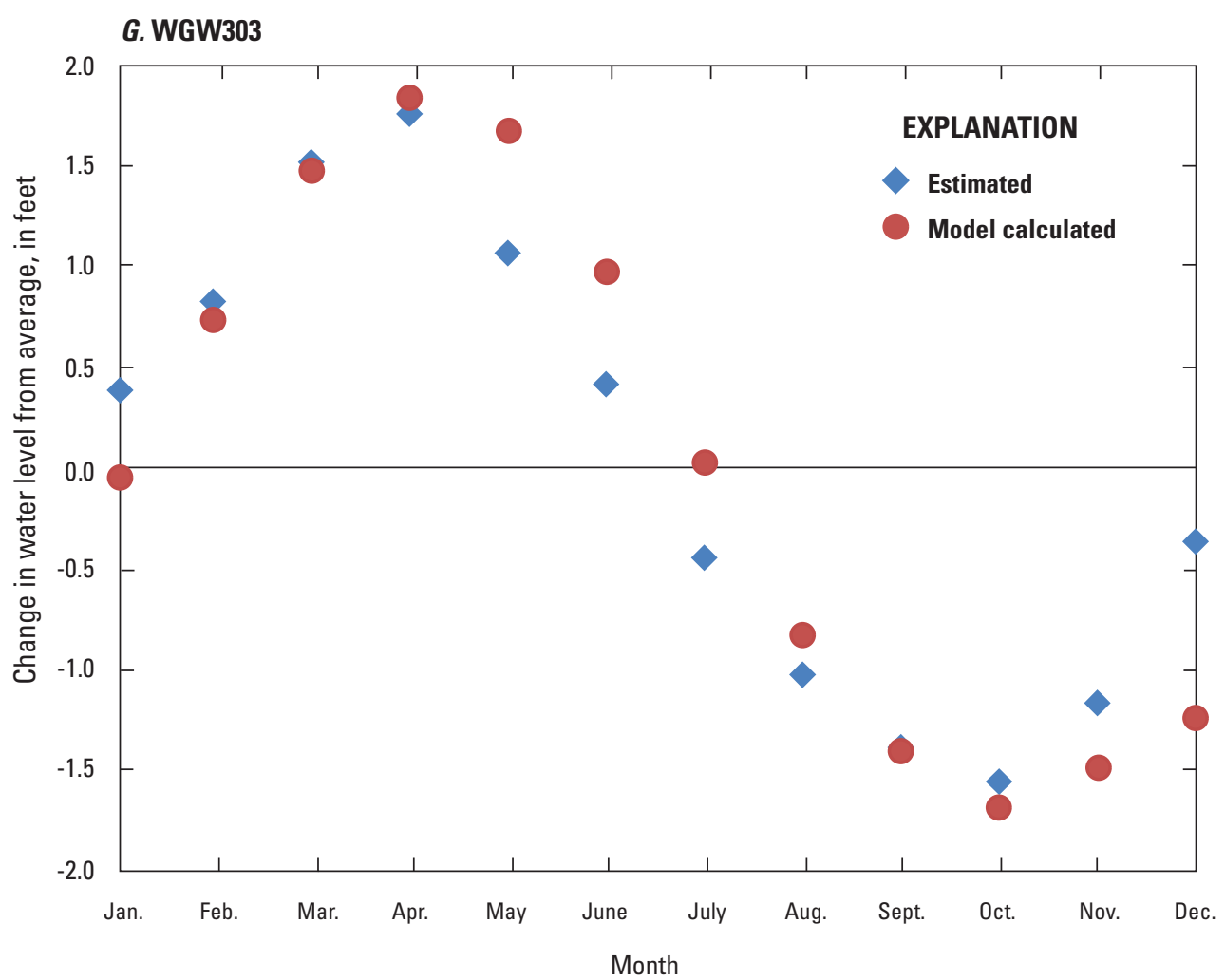

\section{H. WGW304}

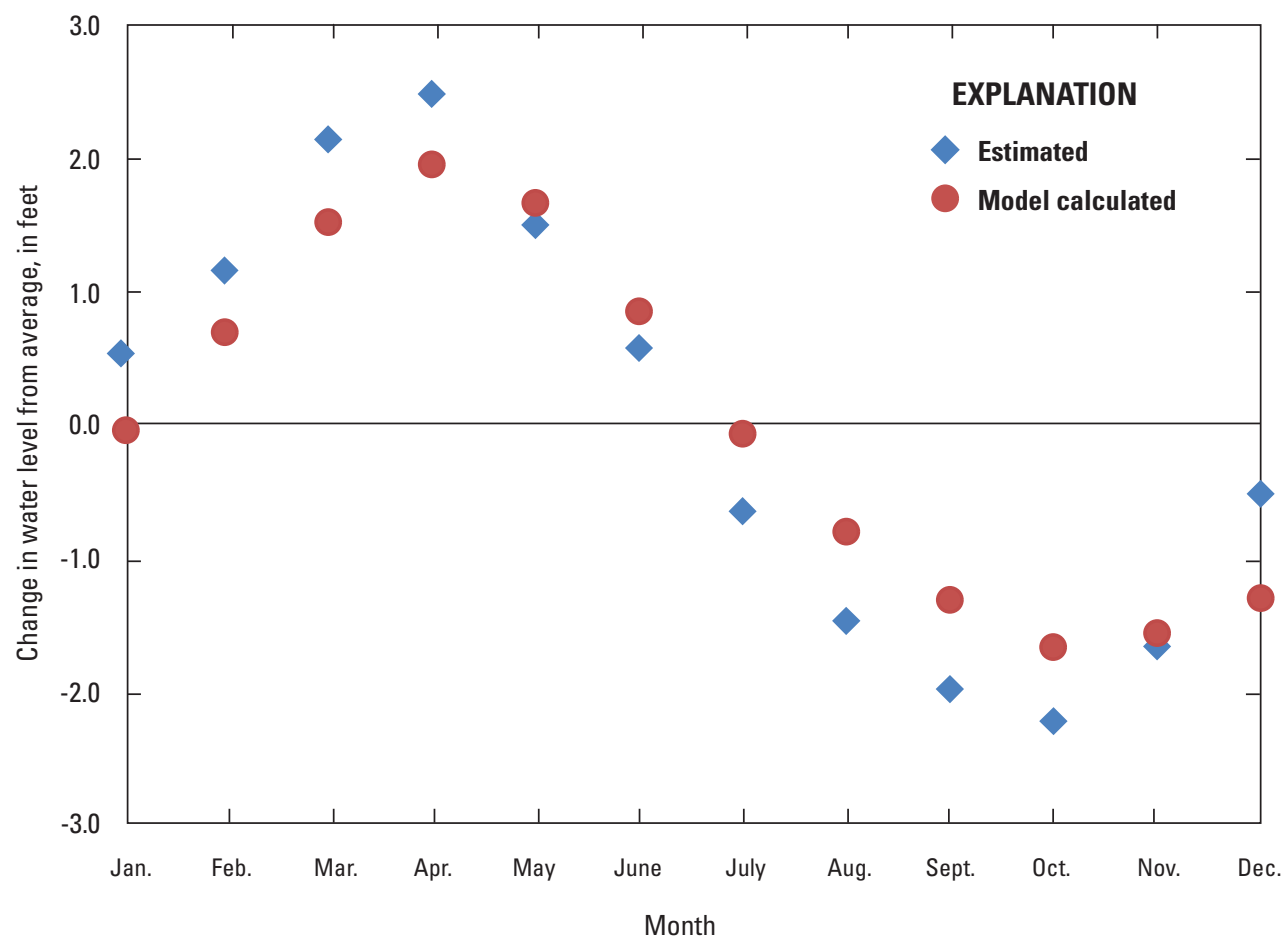

Figure 11. Comparison of monthly departure from average conditions for model-calculated and estimated water levels for observation wells $A$, WGW285; $B$, WGW286; C, WGW 287; D, WGW 290; E, WGW291; F, WGW293; G, WGW303; H, WGW304; I, WGW305; J, WGW313; and K, WGW320 in the Big River Management Area, central Rhode Island. 

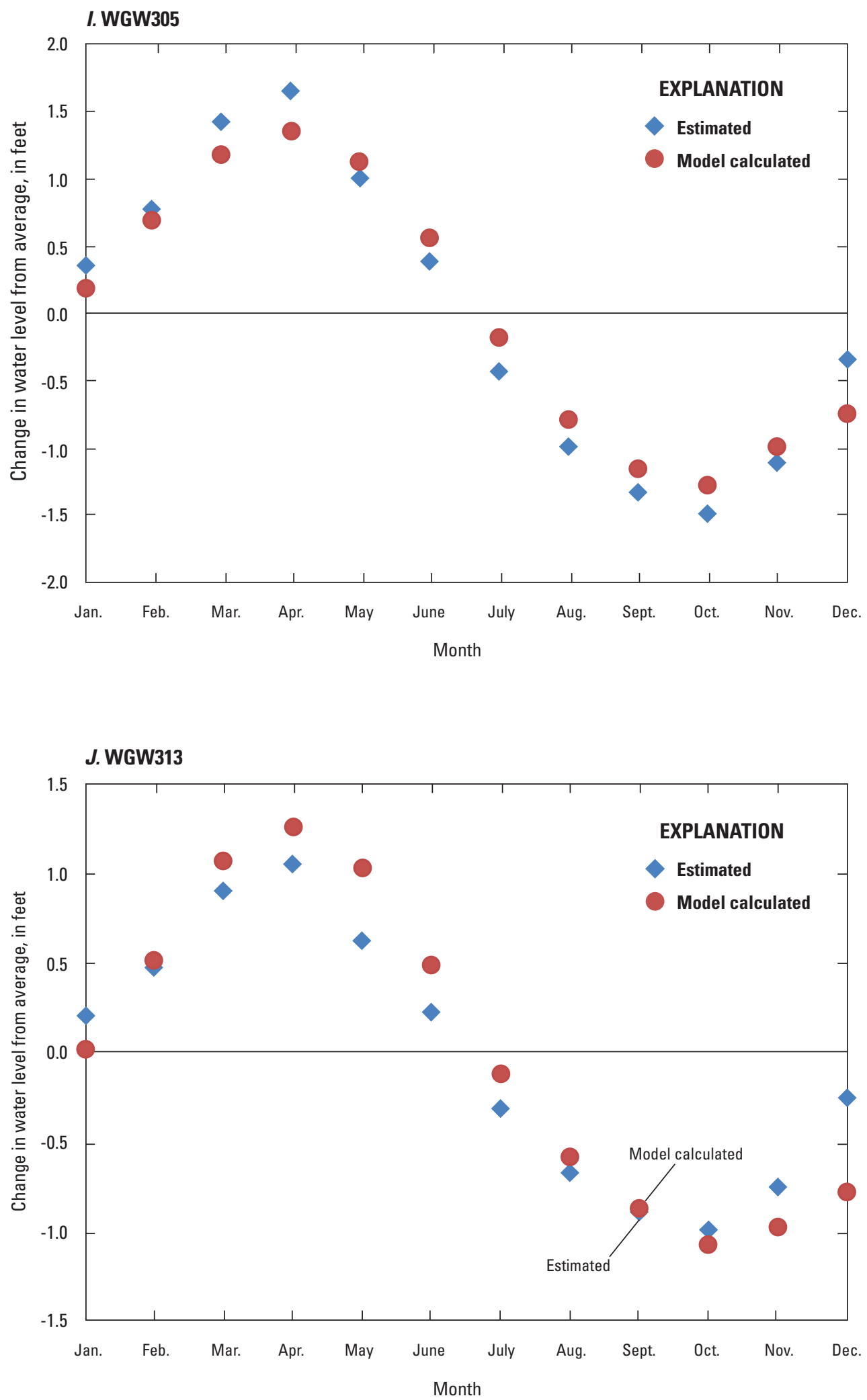

Figure 11. Comparison of monthly departure from average conditions for model-calculated and estimated water levels for observation wells $A$, WGW285; $B$, WGW286; C, WGW 287; $D$, WGW 290; E, WGW291; F, WGW293; G, WGW303; H, WGW304; I, WGW305; J, WGW313; and K, WGW320 in the Big River Management Area, central Rhode Island. 


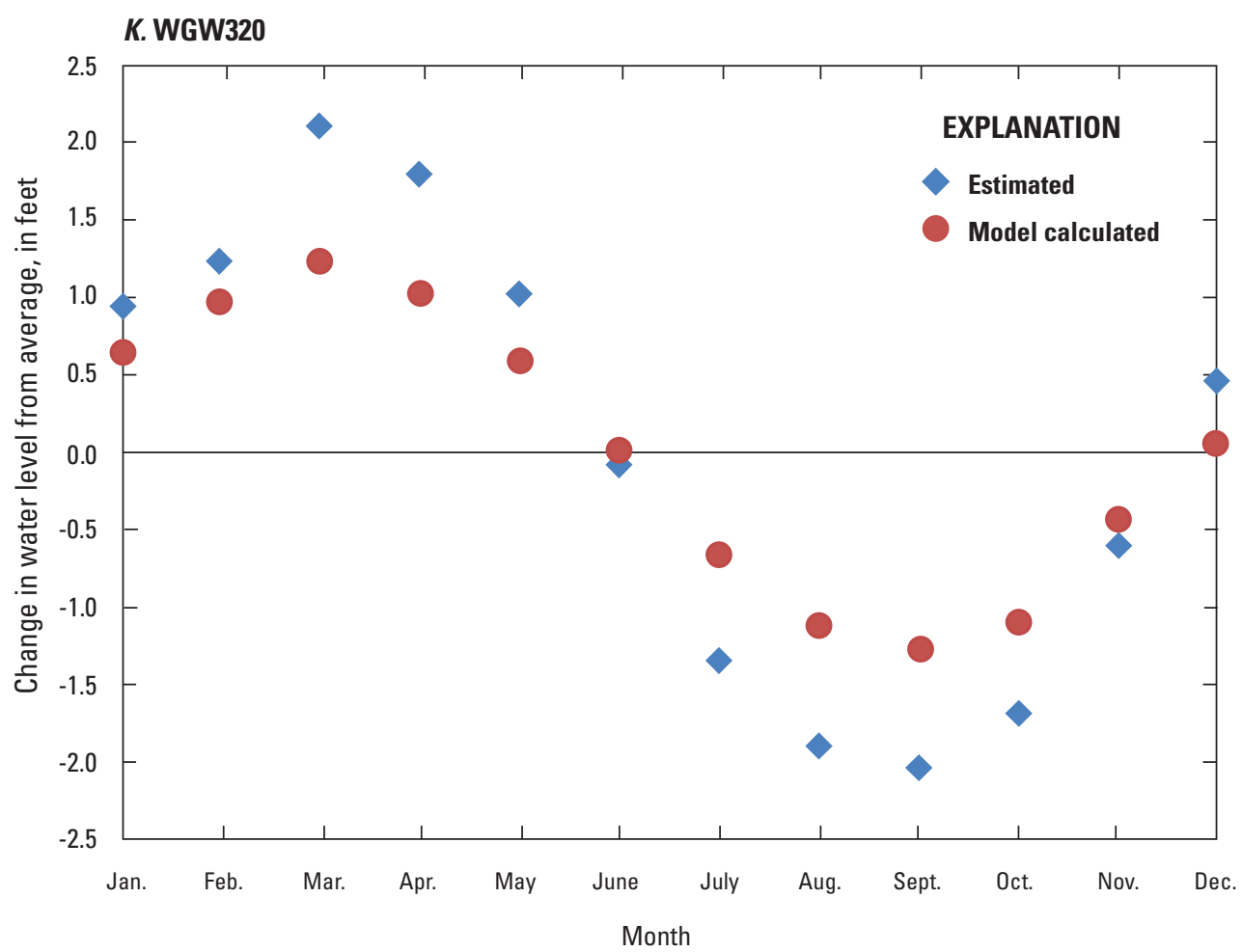

Figure 11. Comparison of monthly departure from average conditions for model-calculated and estimated water levels for observation wells $A$, WGW285; $B$, WGW286; $C$, WGW 287; $D$, WGW 290; E, WGW291; F, WGW293; G, WGW303; H, WGW304; I, WGW305; J, WGW313; and K, WGW320 in the Big River Management Area, central Rhode Island.

More recent studies have been conducted to develop water-supply sources that could be utilized on a year-round basis (Blake Martin, Weston and Sampson, Inc., written commun., 2009). As part of these more recent studies, the viability of two well sites in the northern part of the BRMA near the southern extent of the Flat River Reservoir was explored (WGW443 and WGW444, fig. 1). Although this area is the narrowest part of the productive zone of the aquifer (figs. 6 and 7), the assumption was that induced infiltration from the reservoir could potentially satisfy pumping demands from this part of the aquifer, thereby limiting adverse effects to other more ecologically sensitive surface-water features in the BRMA.

Previous investigations in the BRMA did not provide hydrologic information on the connection between the reservoir and the underlying aquifer system (Craft, 2001; Stone and Dickerman, 2002). Water-level data collected from 48-hour aquifer tests as part of those studies did not provide the necessary data for subsequent modeling analyses to properly determine the interaction between groundwater and surface water in this area (Granato and others, 2003; Granato and Barlow, 2005).

Recent water-resources investigations (Weston and Sampson, Inc., written commun., 2010) included aquifer tests in similar locations as the previous study (Craft, 2001), but investigations were conducted for a longer time period ( 5 days instead of 2 days) to determine whether the reservoir could contribute water to the pumping wells by induced infiltration and to assess pumping effects on nearby wetlands. The aquifer test consisted of two 8-in. wells (WGW443 and WGW444, fig. 14) simultaneously pumped at $550 \mathrm{gal} / \mathrm{min}$ and $490 \mathrm{gal} / \mathrm{min}$, respectively, for 5 days.

\section{Simulation of Short-Term Pumping}

A comparison of measured and model-calculated water levels in response to 5 days of continuous pumping during the aquifer test conducted from December 16 to 21, 2009, was done to assess how well the model matched the response of the aquifer to a pumping stress. This information was used to improve the model calibration (described previously) near the test wells and to better understand groundwater and surfacewater interactions in nearby wetlands. Adjustments to the model included changes in the simulated leakance between the reservoir and the underlying groundwater system and the extent and hydraulic conductivity of the glaciolacustrine deposits that underlie the reservoir and are prevalent throughout the northern part of the BRMA (figs. 6-7). 

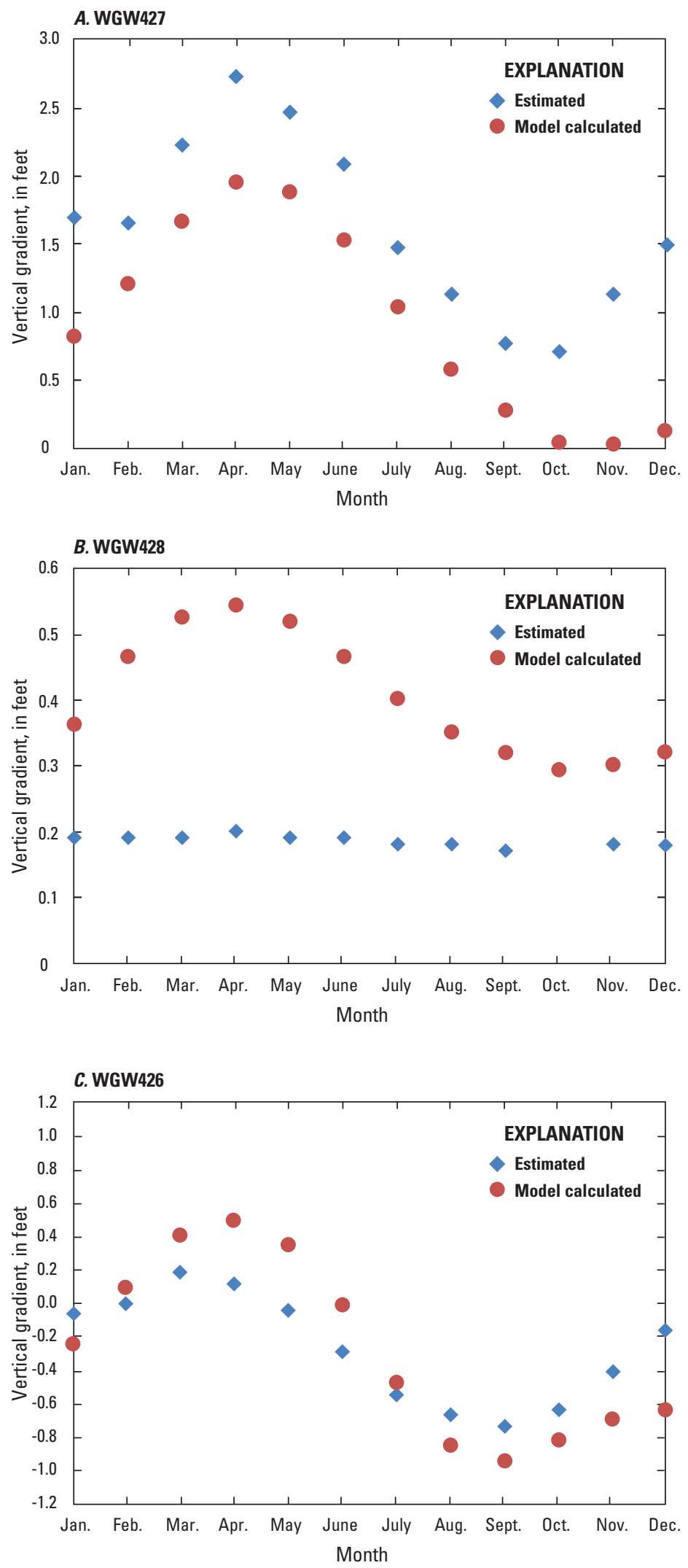

Figure 12. Comparison of changes in model-calculated and estimated vertical gradients with time at $A$, Reynolds Pond Swamp (WGW427); $B$, Cedar Swamp (WGW428); and C, Scarborough Swamp (WGW426), Big River Management Area, central Rhode Island. 

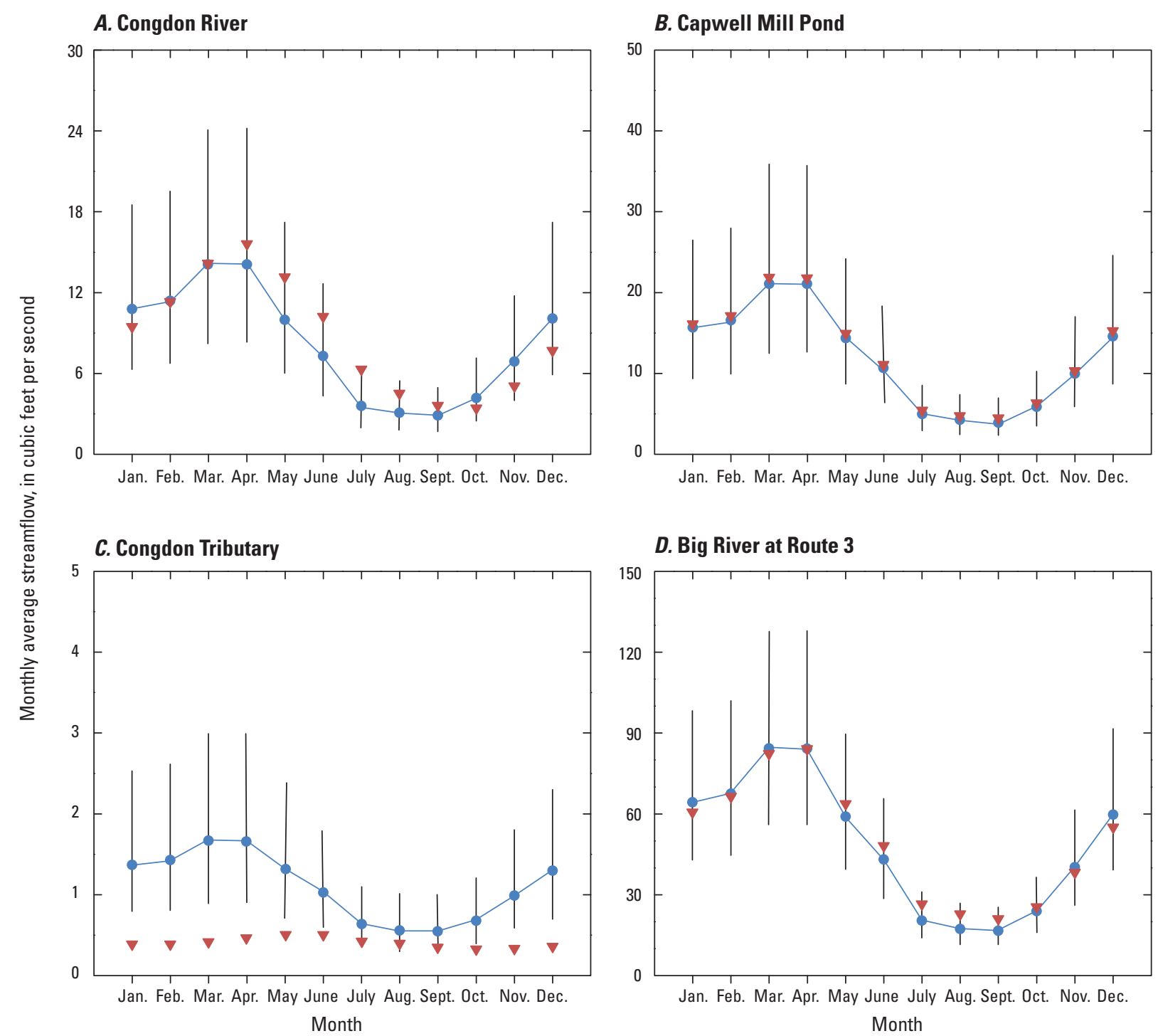

\section{Big River at Route 3}

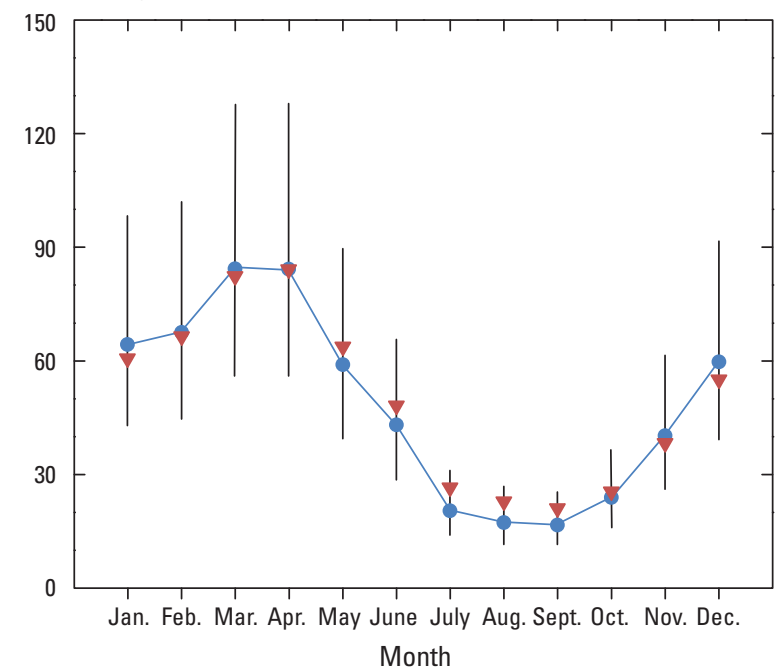

\section{EXPLANATION}

| 95-percent confidence interval of estimated average-monthly streamflow, from 1960 through 2006

- Estimated average-monthly streamflow, from 1960 through 2006

$\nabla$ Model-calculated mid-monthly streamflow

Figure 13. Comparison of model-calculated and estimated streamflows for long-term average monthly conditions from 1960 through 2006 in the Big River Management Area, central Rhode Island. 


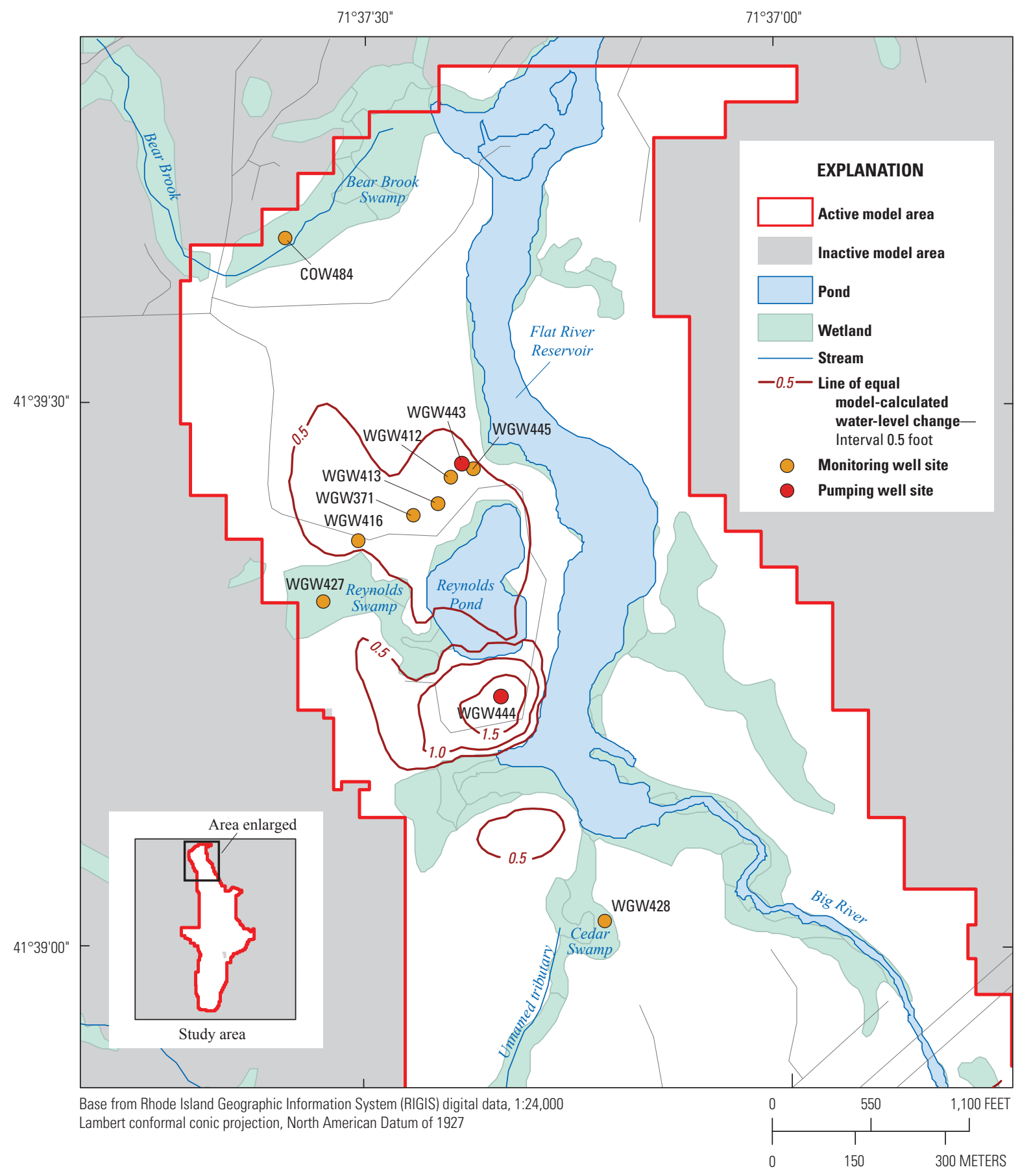

Figure 14. Location of test wells WGW443 and WGW444 and monitoring wells measured during the aquifer test conducted from December 16 to 21, 2009, and model-calculated water-level changes in response to 5 days of simulated pumping in the Big River Management Area, central Rhode Island. 


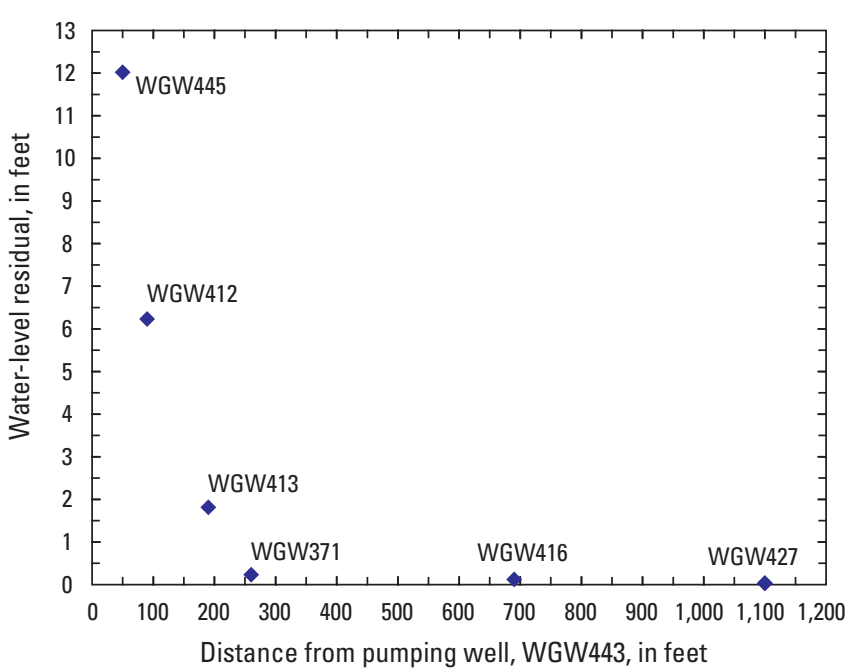

Figure 15. Comparison between measured and modelcalculated water-level changes with distance at monitoring wells measured at the end of the 5-day aquifer test conducted from December 16 to 21, 2009, Big River Management Area, central Rhode Island.

\section{Effects of Model Discretization}

This model provided a reasonable representation of the change in water levels observed during the aquifer test, in particular, at the wells located at a distance greater than $200 \mathrm{ft}$ from the pumped wells (fig. 15). The match between the measured and model-calculated water levels at observation wells within $200 \mathrm{ft}$ of the pumped well was poor despite adjustments made in the model to the geologic framework and hydraulic conductivity of these deposits.

The differences between the observed and simulated water-level changes may be attributed to the model grid discretization rather than the model conceptualization of the hydrogeologic conditions. The model underpredicted water levels in the observation wells closest to the pumped well (within $200 \mathrm{ft}$ ) (fig. 16A-C) but appears to provide a much better match to measured values at distances greater than $200 \mathrm{ft}$ (fig. 16D-F).

The underpredicted match of changes in water levels (drawdowns) near the pumped well may be the result of the simulated pumping applied over the entire $50-\mathrm{ft}$ by $50-\mathrm{ft}$ model cell, rather than at the 8-in. diameter well casing that occurs in the aquifer. Also, model-calculated water levels are averaged for the entire grid cell, thereby creating the potential to dampen the water-level response in a model cell to pumping, particularly where there are large changes in water levels over short distances close to the pumped well. This grid discretization effect has been shown to diminish with increasing distance from the pumped well (Reilly and Harbaugh, 2004).

\section{Effects of Storage in Till Deposits}

Although the match between the model-calculated and measured water levels improves with distance from the pumped well, the initial simulation of the 5-day aquifer test showed a larger change in water level than the measured response ( $0.9 \mathrm{ft}$ compared with $0.5 \mathrm{ft}$ ) at the observation well (WGW427) beneath the Reynolds Pond wetland site farthest from the pumped well (fig. 14). This model overprediction of the water-level changes at this site may be attributed to the model representation of the contact between the upland till areas and the adjacent glacial stratified deposits given the proximity of this site to that boundary. This contact is represented in the model as a no-flow boundary with the inflow from the uplands specified as a fixed rate of enhanced recharge at the water table along the active model area.

The upland till area adjacent to WGW427 was mapped as till deposits greater than $20 \mathrm{ft}$ (fig. 6) compared to the less than 10-ft zone mapped throughout most of the study area (Stone and Dickerman, 2002). To test the hypothesis that the model overprediction of drawdown was related to the upland till contact, simulations were made with an increased storage capacity along the upland till contact to account for storage effects in the till deposits not represented with no-flow boundary condition. When the storage coefficient value was increased from 0.00001 to 0.1 in this area, the match between the model-calculated and observed water levels greatly improved from initially overpredicting drawdown by $0.4 \mathrm{ft}$ to exactly matching the measured value. A similar response was not calculated for the other observation wells located closer to the pumped wells, indicating there may be a localized connection between the till upland and stratified glacial deposits that is not properly accounted for with the enhanced recharge/no-flow boundary condition, but this effect may not extend much beyond this hydrogeologic contact. Therefore, for this analysis, a storage coefficient value of 0.1 was simulated in areas where the till thickness was greater than $20 \mathrm{ft}$ (fig. 6).

Increasing the simulated storage properties in the areas representing the contact between the till and the stratified glacial deposits does not increase the amount of water entering the flow system but only affects the timing of the release of the recharge specified along this contact to the aquifer. The fact that the increased storage improved the match between model-calculated and measured water levels after 5-days of pumping suggests that the timing of the release of water from the uplands may not be properly accounted for by specifying recharge along the no-flow boundary condition or the possibility of an additional source, or sources of water, not currently represented in the model, which also may improve the match near the upland till contact. Additional sources could include the contribution of water from fractured rock along the upland til contact or underlying the stratified glacial drift deposits not accounted for in the model; a similar response was observed in a fractured rock system in northeastern Massachusetts (Lyford and others, 2003). 
A. WGW445 (50 feet from pumping well WGW443)

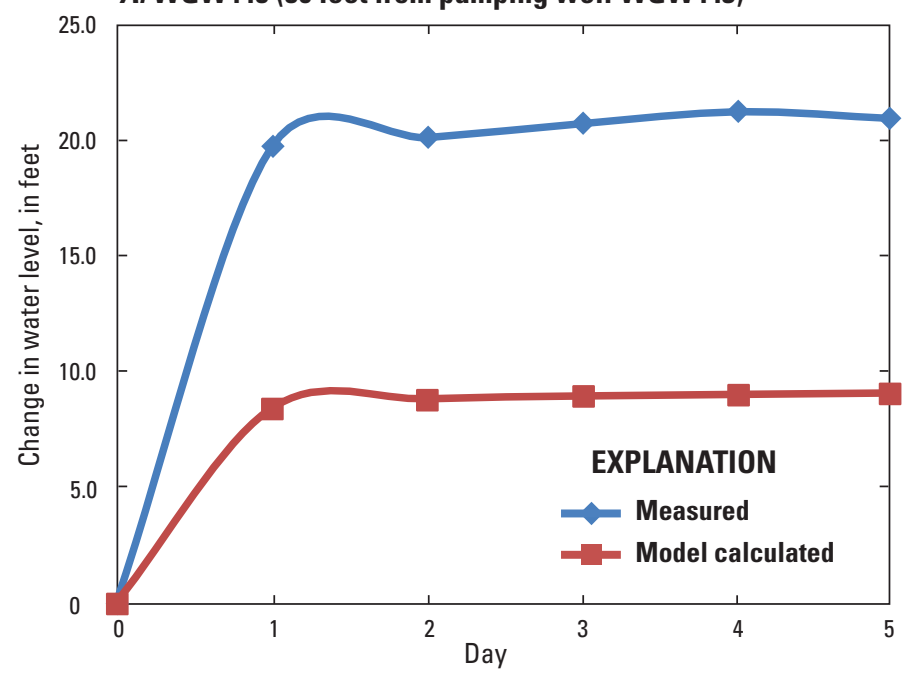

B. WGW412 (90 feet from pumping well WGW443)

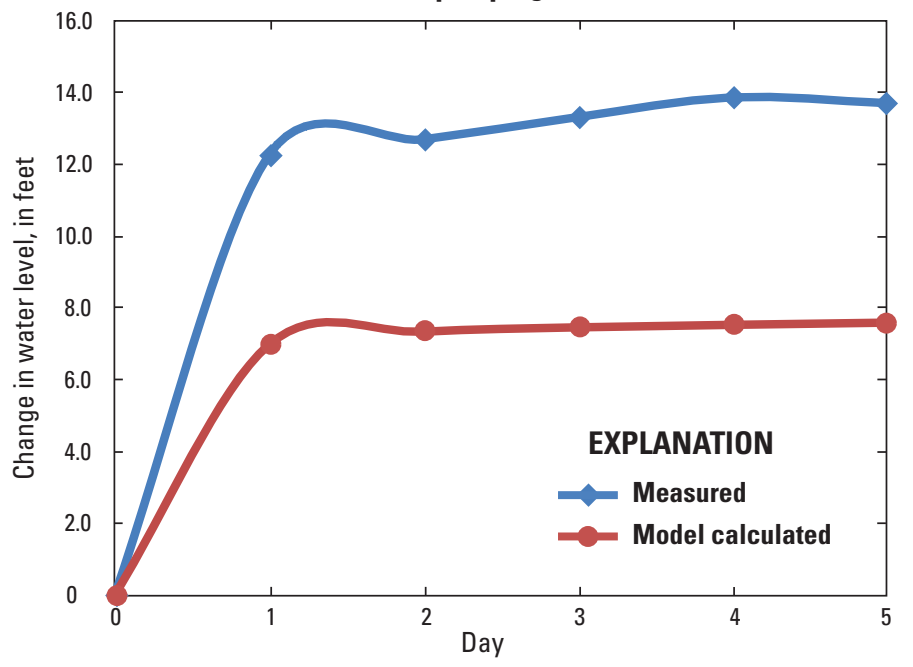

C. WGW413 (190 feet from pumping well WGW443)

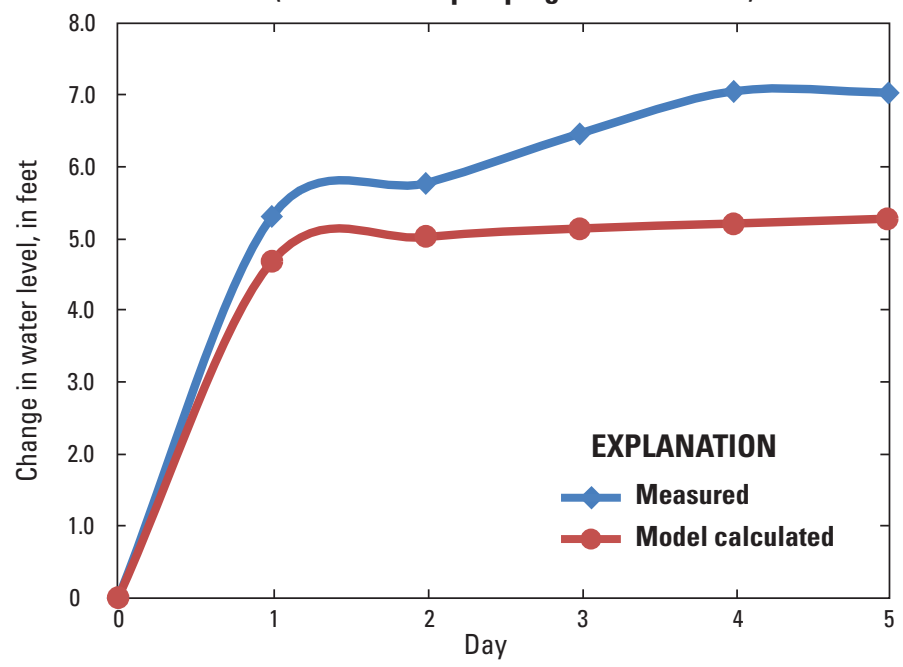

Figure 16. Comparison between measured and model-calculated water-level changes with distance at monitoring wells measured at the end of the 5-day aquifer test conducted from December 16 to 21, 2009, Big River Management Area, central Rhode Island. $A$, WGW445; $B$, WGW412; C, WGW413; D, WGW371; $E$, WGW416; and F, WGW427. 
D. WGW371 (260 feet from pumping well WGW443)

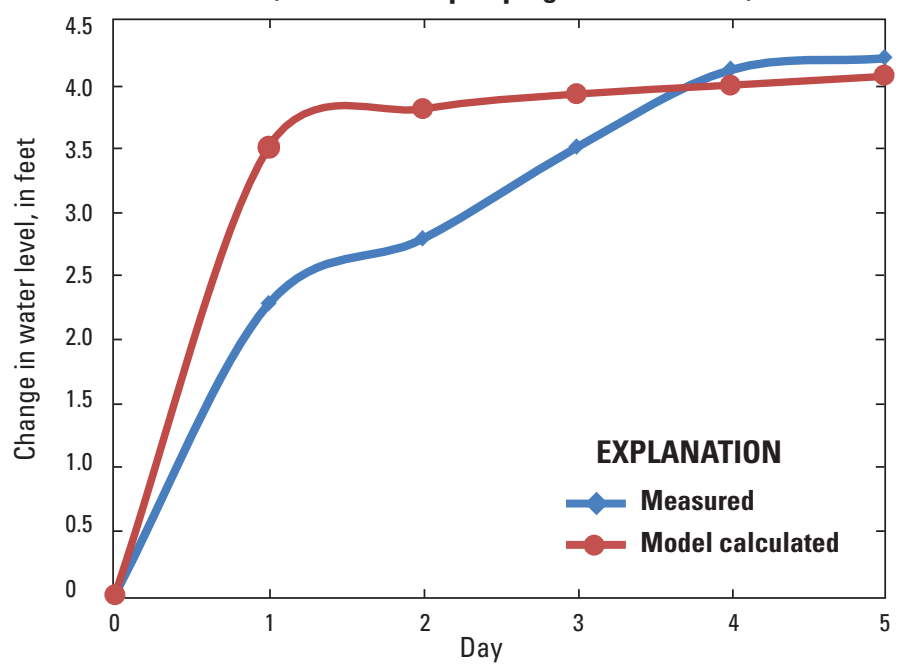

E. WGW416 (690 feet from pumping well WGW443)

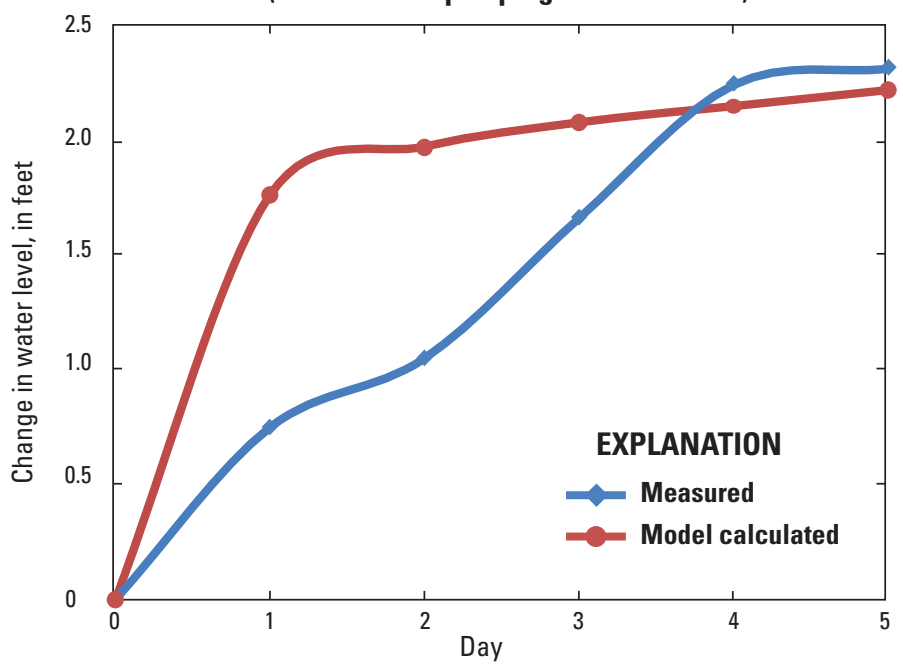

F. WGW427 (1,100 feet from pumping well WGW443)

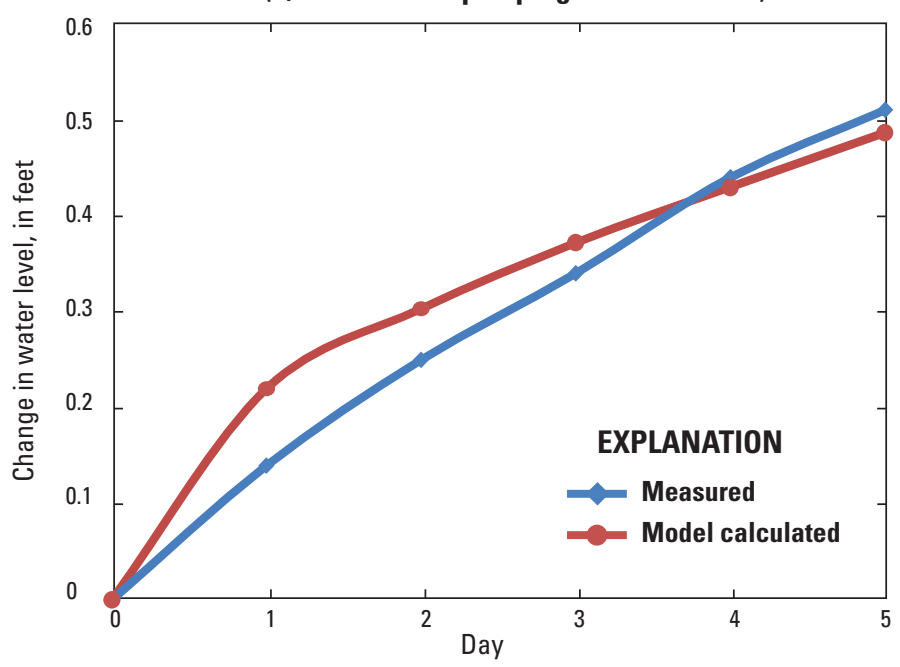

Figure 16. Comparison between measured and model-calculated water-level changes with distance at monitoring wells measured at the end of the 5-day aquifer test conducted from December 16 to 21, 2009, Big River Management Area, central Rhode Island. $A$, WGW445; $B$, WGW412; C, WGW413; D, WGW371; $E$, WGW416; and $F$, WGW427.-Continued 


\section{Effects of Changes in Reservoir Stage}

The aquifer test was conducted in December, a time when the reservoir typically is lowered for weed control, but the reservoir was not lowered during the time that this test was conducted. Therefore, a comparison of the simulated changes in water levels under both conditions was made to determine if the water level in the reservoir could affect the results of the aquifer test.

Results of this comparison showed that the difference in water-level changes after 5 days of simulated pumping between flooded or drained conditions in the reservoir area were negligible, indicating that the aquifer-test results would not be affected by the water level of the reservoir area (table 2). This result can be explained in part by an analysis of the water budget for these different hydrologic conditions (table 3). In both instances (reservoir area flooded or drained), most of the water (about 63 percent) discharging to the pumped wells was derived from aquifer storage and, therefore, induced infiltration from the reservoir area is not an important source of water in the first 5 days of pumping.

Table 2. Measured and model-calculated water-level declines in response to 5 days of continuous pumping at pumping test sites WGW443 and WGW444, Big River Management Area, central Rhode Island.

[Positive value indicates water-level decline from no-pumping condition. Pumping wells are located in model layer 5]

\begin{tabular}{lccccccc}
\hline Well name & $\begin{array}{c}\text { Model } \\
\text { row }\end{array}$ & $\begin{array}{c}\text { Model } \\
\text { column }\end{array}$ & $\begin{array}{c}\text { Model } \\
\text { layer }\end{array}$ & $\begin{array}{c}\text { Distance from } \\
\text { pumping well } \\
\text { (feet) }\end{array}$ & $\begin{array}{c}\text { Water-level change } \\
\text { model-calculated } \\
\text { reservoir present } \\
\text { (feet) }\end{array}$ & $\begin{array}{c}\text { Water-level change } \\
\text { model-calculated } \\
\text { reservoir drained } \\
\text { (feet) }\end{array}$ & $\begin{array}{c}\text { Difference in } \\
\text { model-calculated } \\
\text { water levels } \\
\text { (reservoir present } \\
\text { minus drained) } \\
\text { (feet) }\end{array}$ \\
\hline WGW445 & 47 & 57 & 5 & 50 & 9.07 & 8.94 & 0.13 \\
WGW412 & 47 & 54 & 5 & 90 & 7.59 & 7.47 & 0.12 \\
WGW413 & 50 & 52 & 5 & 190 & 5.29 & 5.19 & 0.10 \\
WGW371 & 52 & 50 & 5 & 260 & 4.01 & 3.97 & 0.04 \\
WGW416 & 54 & 44 & 5 & 690 & 2.22 & 2.18 & 0.04 \\
WGW427-0001 & 61 & 39 & 1 & 1,100 & 0.07 & 0.07 & 0.00 \\
WGW427-0023 & 61 & 39 & 3 & 1,100 & 0.48 & 0.47 & 0.01 \\
\hline
\end{tabular}

Table 3. Source of water to pumping wells at a total pumping rate of 1.5 million gallons per day after 5 days of pumping and for long-term monthly conditions.

\begin{tabular}{|c|c|c|c|c|}
\hline Source of water to pumping wells & $\begin{array}{l}\text { 1B.I.-5 days } \\
\text { (in percent) }\end{array}$ & $\begin{array}{c}\text { August } \\
\text { (in percent) }\end{array}$ & $\begin{array}{l}\text { 2B.0.-5 days } \\
\text { (in percent) }\end{array}$ & $\begin{array}{c}\text { December } \\
\text { (in percent) }\end{array}$ \\
\hline Storage & 63 & 13 & 64 & 0 \\
\hline Induced Infiltration from Reservoir & 22 & 52 & 8 & 7 \\
\hline Captured flow to Reservoir & 6 & 7 & 24 & 64 \\
\hline Reductions in streamflow away from reservoir & 9 & 28 & 4 & 29 \\
\hline
\end{tabular}

\footnotetext{
${ }^{1}$ B.I. is the condition in which the control boards were in place creating the reservoir; condition that occurs typically from March through October.

${ }^{2}$ B.O. is the condition in which the control boards were removed and the reservoir drained for weed control; a condition that occurs typically from November through February.
} 


\section{Simulation of Long-Term Pumping}

Simulations were made to assess the effects of continuous (24-hr/day) pumping at WGW443 and WGW444 at rates of $550 \mathrm{gal} / \mathrm{min}$ and $490 \mathrm{gal} / \mathrm{min}$, respectively, for long-term average monthly conditions and to determine whether the water-level changes observed after 5 days of pumping would remain stable or additional declines would occur if pumping continued over a longer period, as it would if these sites were to be developed as water-supply sources. A comparison was made of simulated water-level changes between long-term pumping and pumping for a brief period ( 5 days) to determine if this aquifer system would reach equilibrium after 5 days of pumping.

\section{Effect of Increased Pumping Time}

After 5 days of pumping, measured water levels declined by only about $0.5 \mathrm{ft}$ near Reynolds Pond (fig. 17); however, when pumping at the same rates was simulated for long-term average monthly conditions for a typical December when the reservoir area is drained (fig. 18A) and for a typical August when the reservoir area is flooded (fig. 18B), the water-level declines calculated at the water table were $6 \mathrm{ft}$ and $5 \mathrm{ft}$, respectively. This continued decline in model-calculated water levels with time suggests that, after 5 days of pumping, this aquifer system has not yet reached equilibrium with respect to this pumping stress, and that an aquifer test conducted for only a 5-day period may not be sufficiently long to adequately assess the effects of pumping on the wetlands in the BRMA or on wetland systems in similar hydrogeologic settings found throughout Rhode Island.

\section{Effect of Changes in Reservoir Stage}

Model simulation of nonpumping conditions, for typical December conditions when the reservoir area is normally drained, indicates the water level in the reservoir area is lower relative to the surrounding aquifer resulting in about $6.4 \mathrm{ft}^{3} / \mathrm{s}$ (or $4.1 \mathrm{Mgal} / \mathrm{d}$ ) of groundwater discharge to the part of the Big River that flows through this area. During typical August conditions when the reservoir area is normally flooded, the hydraulic gradient between the groundwater system and the reservoir is reduced resulting in little hydrologic interaction between the underlying aquifer and the reservoir. As a result, when the reservoir area is flooded (March-October), there is greater potential for the reservoir to be a source of water to the pumped wells through induced infiltration. During the year when the reservoir area is drained (November-February), the potential source of water to nearby pumped wells is from a reduction in groundwater discharge from the aquifer to the part of the Big River that flows through the drained part of the reservoir (fig. 5).

A comparison was made of the model-calculated sources of water to the pumped wells during the 5-day simulation and for the long-term monthly conditions (table 3 ) to determine the sources of the water pumped from the wells and whether the sources of water changed with increased pumping times. Results of the model simulations indicated that after 5 days of continuous pumping, the resulting declines in water levels in the nearby wetlands were typically less than $1 \mathrm{ft}$, and this change in water level did not appear to differ much between the condition when the reservoir area was flooded or drained. In both instances, most (63-64 percent) of the water pumped from the wells was derived from aquifer storage. In the scenario in which the reservoir area was flooded, the remaining sources of water included (1) induced infiltration from the reservoir (22 percent), (2) reduction in discharge to nearby streams ( 9 percent), and (3) reduction in groundwater discharge to the reservoir (6 percent). In the scenario in which the reservoir area was drained, the remaining sources of water included (1) reduction in groundwater discharge to the reservoir (24 percent), (2) induced infiltration from the Big River in the area of the drained reservoir (8 percent), and (3) reduction in discharge to nearby streams (4 percent).

When continuous pumping was simulated for long-term average monthly-recharge conditions, the resulting declines in water levels in the vicinity of the pumping wells were about 5 to $6 \mathrm{ft}$. These changes in water levels were on average about $1 \mathrm{ft}$ greater when the reservoir area was drained compared to when it was flooded (fig. 18B). In the scenario in which the reservoir area was flooded, more than half (52 percent) of the water withdrawn from the wells was derived from induced infiltration from the reservoir, while the remaining sources of water included (1) reduction in discharge to nearby streams ( 28 percent), (2) aquifer storage (13 percent), and (3) reduction in groundwater discharge to the reservoir (7 percent). In the scenario in which the reservoir area was drained, most (64 percent) of the water pumped from the wells was derived from reduction in groundwater discharge to the reservoir area, while the remaining sources of water included reduction in discharge to nearby streams (29 percent) and induced infiltration from the Big River in the area of the drained reservoir (7 percent).

Differences in drawdowns between December and August were about $2 \mathrm{ft}$ in the vicinity of Reynolds Swamp (fig. 18), indicating that even if pumping rates were to remain constant throughout the year, the long-term effect of pumping on this aquifer system appears to vary depending on whether or not the reservoir area is flooded.

This analysis suggests that the differences in both waterlevel declines and the sources of water to the pumped wells varied with time and were dependent on whether the reservoir area was drained or flooded. After water levels have declined so that the hydraulic gradient between the nearby surface waters and the underlying aquifer is sufficiently large, the reservoir becomes a primary source of water; the contribution of water from storage during early pumping times would be replaced by increased induced infiltration from the reservoir and by reductions in groundwater discharge to the reservoir and nearby streams (table 3 ).

These results also suggest that the differences between drawdowns for 5 days of pumping and under long-term 


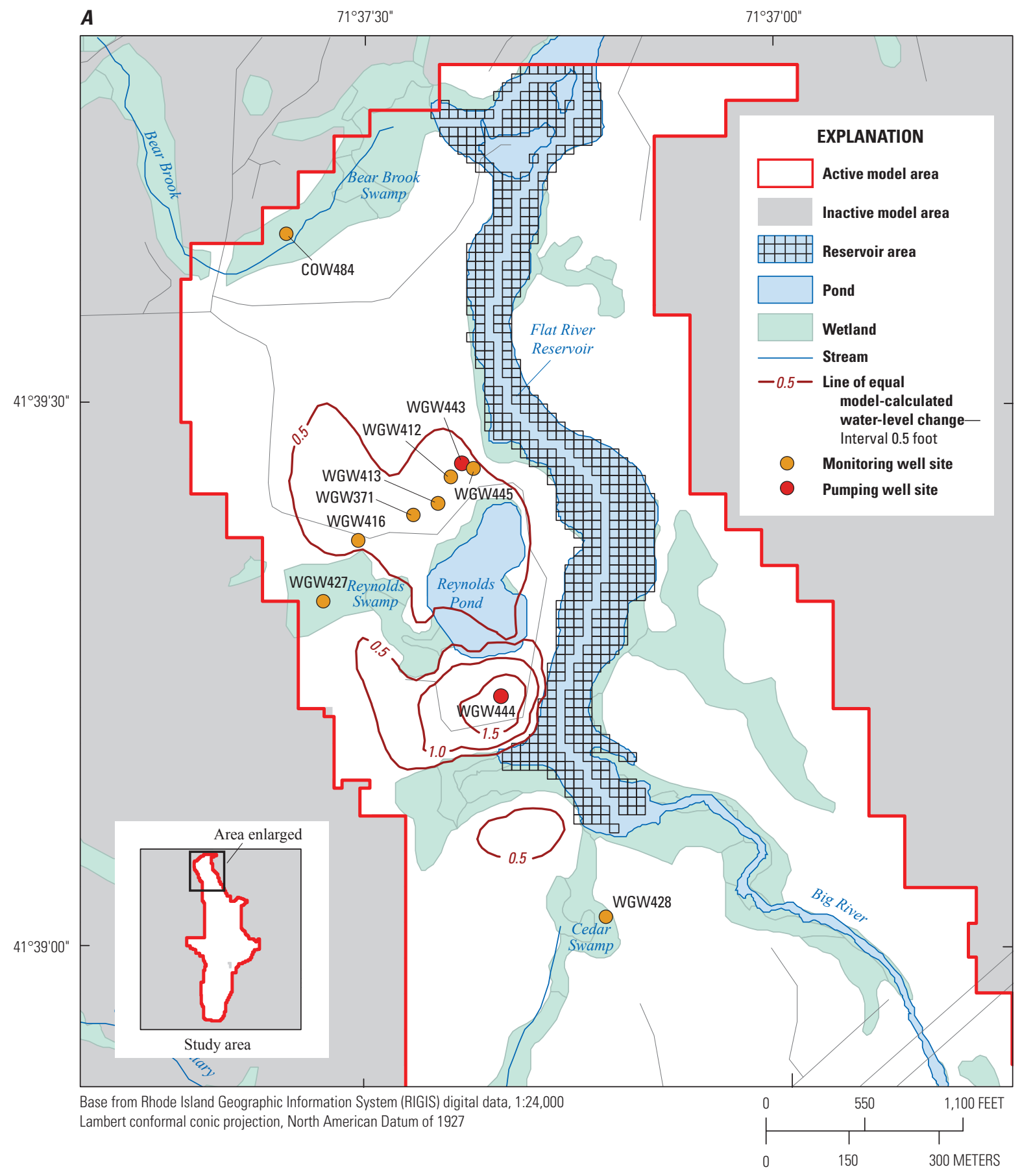

Figure 17. Model-calculated water-level declines $A$, after 5 days of continuous pumping for December conditions when reservoir area is drained and $B$, in response to continuous pumping for long-term average December conditions when reservoir area is drained, Big River Management Area, central Rhode Island. 


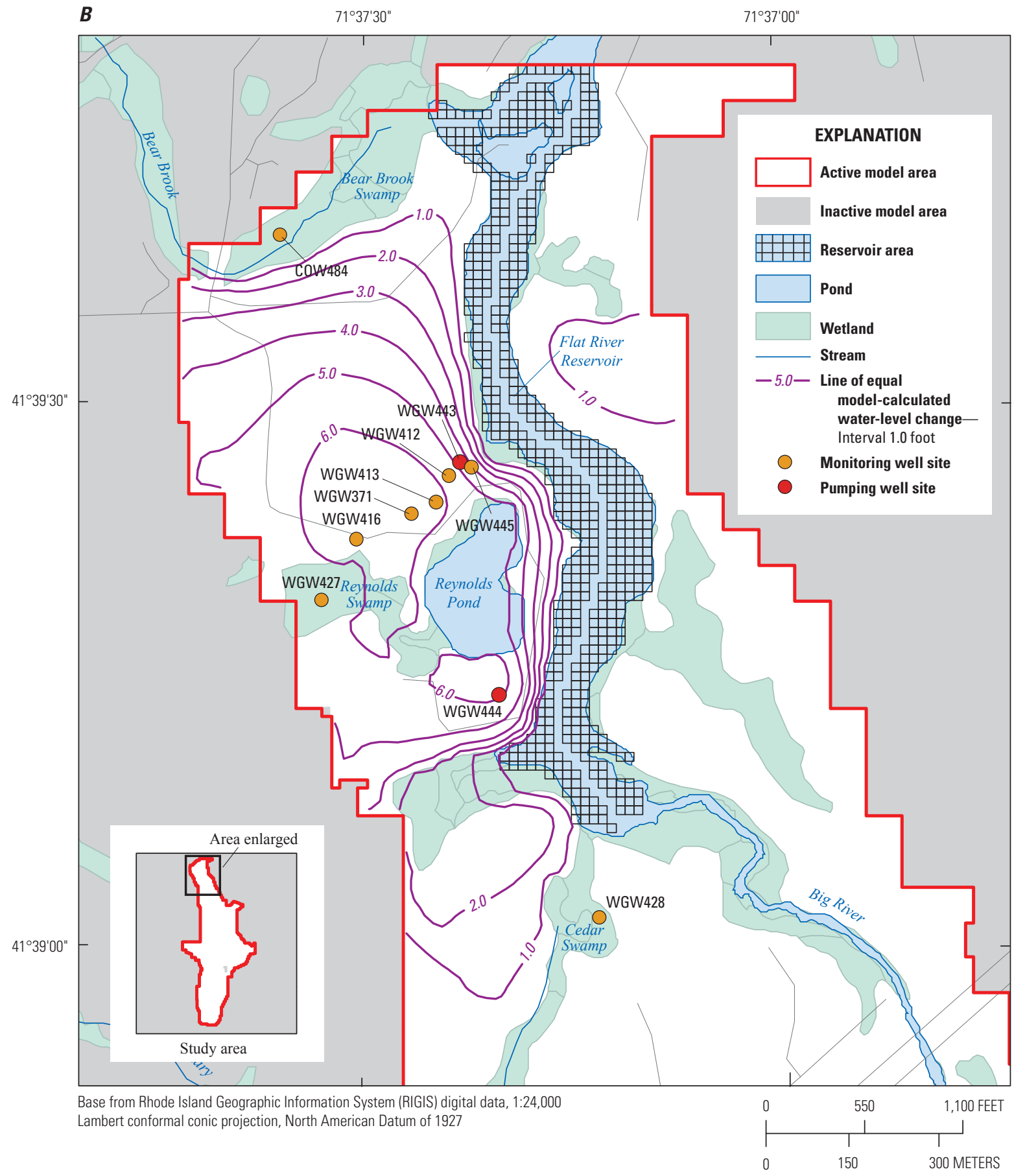

Figure 17. Model-calculated water-level declines $A$, after 5 days of continuous pumping for December conditions when reservoir area is drained and $B$, in response to continuous pumping for long-term average December conditions when reservoir area is drained, Big River Management Area, central Rhode Island. 


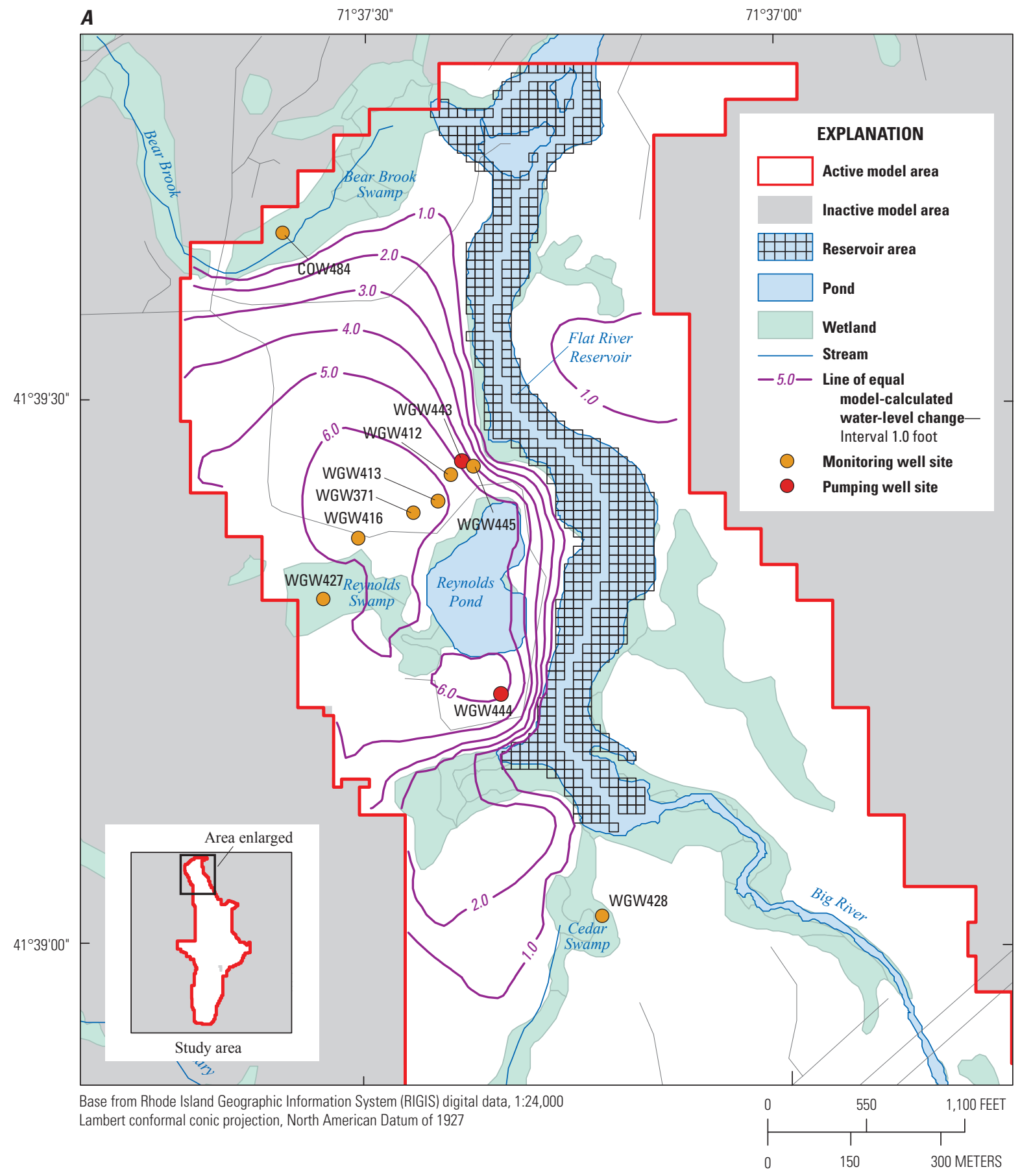

Figure 18. Model-calculated water-level declines in response to continuous pumping for $A$, long-term average December conditions when reservoir area is drained and for $B$, long-term average August conditions when reservoir area is flooded, the Big River Management Area, central Rhode Island. 


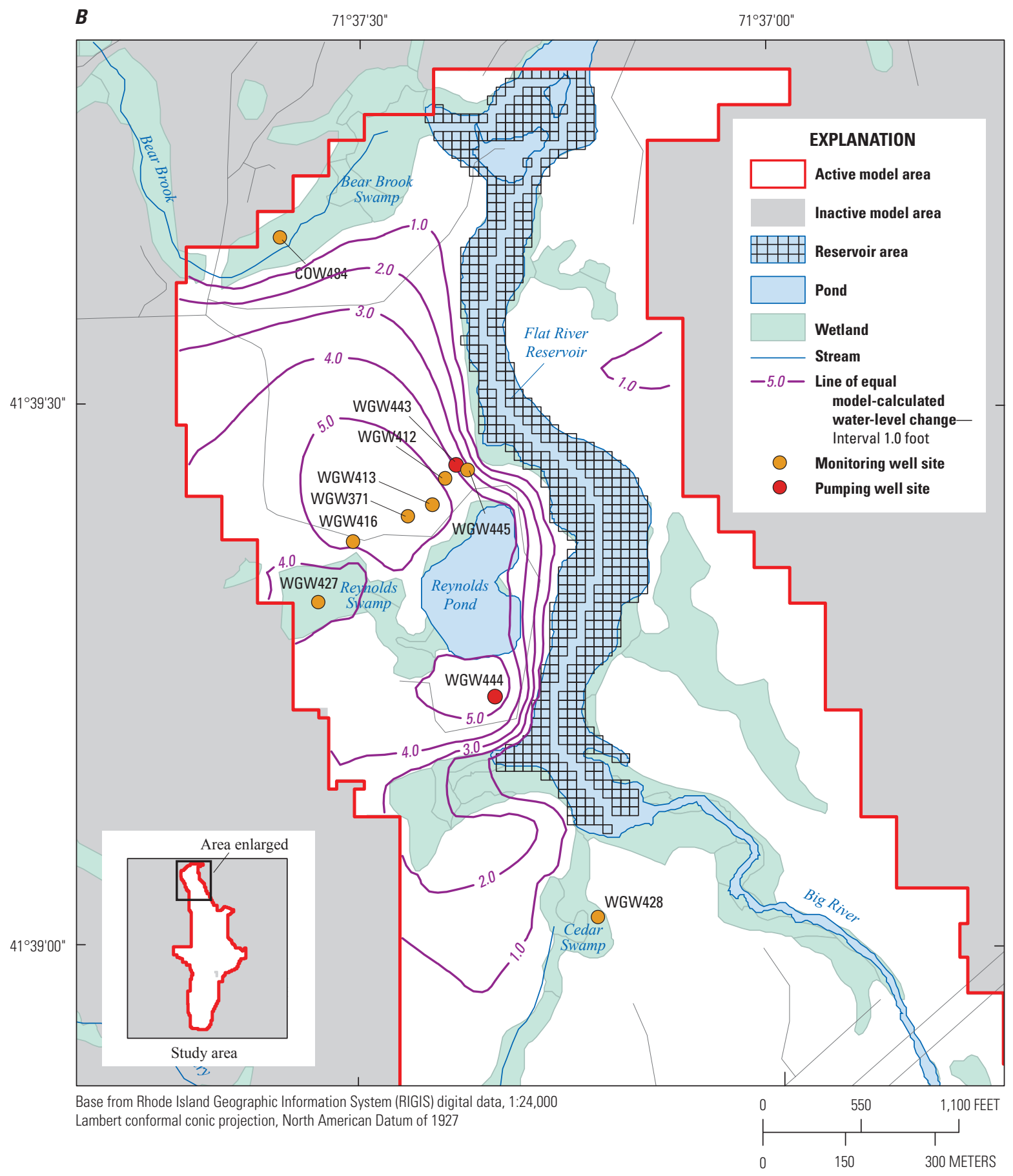

Figure 18. Model-calculated water-level declines in response to continuous pumping for $A$, long-term average December conditions when reservoir area is drained and for $B$, long-term average August conditions when reservoir area is flooded, the Big River Management Area, central Rhode Island. 
monthly conditions (figs. 17-18) may indicate that the waterlevel changes measured as part of the aquifer test are not representative of a stable condition, and water levels may continue to decline with increased time even with constant pumping until the hydraulic gradient between the reservoir and the underlying aquifer is large enough to create enough groundwater flow to the pumped wells to satisfy the pumping rate. These model-calculated drawdowns only reflect the response of the aquifer to the pumping rates simulated in this analysis; if pumping rates were increased, it would be expected that drawdowns and reductions in surface-water flow would increase accordingly.

\section{Simulated Effects of Groundwater Withdrawals on Wetlands}

The model-calculated change in water levels at the Bear Brook, Cedar, Reynolds, and Scarborough Swamps were assessed for the short-term (5-day) pumping period and the long-term pumping period for average conditions for the months of December and August when the reservoir area was drained and flooded (table 4). A fifth site, the Congdon Swamp (fig. 1), was selected as part of the field component of this study (Borenstein and others, 2012) as a control site to compare the potential long-term ecological changes in the four sites listed above to one under unstressed conditions once large-scale withdrawal commence in the BRMA .

Model results indicate that the water-level declines at the Bear Brook, Cedar, Reynolds, and Scarborough Swamps ranged from 0 to $0.2 \mathrm{ft}$ for short-term (5-day) conditions representative of the pump test conducted in December 2009 (fig. 14, table 4). During that pump test, the boards had not yet been removed for weed control and the reservoir was flooded. The model-calculated water-level declines were greatest beneath Cedar Swamp for a maximum decline of about $0.2 \mathrm{ft}$ (fig. 14, table 2). Simulation of the boards removed and the reservoir area drained resulted in the same amount of waterlevel decline as with the boards in place.

Continuous pumping rates of 550 and $490 \mathrm{gal} / \mathrm{min}$ were simulated at WGW443 and WGW444, respectively, for long-term average monthly conditions. Model-calculated water-level declines were determined for the wetland sites for average monthly August and December conditions when the reservoir area is typically flooded and drained. Model results indicate that water-level declines beneath the Bear Brook, Cedar, Reynolds, and Scarborough Swamps ranged from 0 to $3.8 \mathrm{ft}$ for August conditions with the greatest decline (3.8 ft) occurring at Reynolds Swamp. The water-level declines for December conditions, when the boards are typically out and the reservoir area is drained, ranged from 0.1 to $5.8 \mathrm{ft}$ with the greatest declines also occurring at Reynolds Swamp (5.8 ft).

The largest change in water-level declines from August to December conditions occurred at Reynolds Swamp indicating that when the reservoir area is flooded (i.e. August conditions) the water-level declines in this area may be about $2 \mathrm{ft}$ less than for December conditions when the reservoir area is drained. This response does not occur at the other wetland sites (fig. 18, table 4) and may be related to the proximity of Reynolds Swamp to the pumping wells and or its proximity to the upland till boundary (fig. 18).

\section{Limitations of Analysis}

The primary focus of this analysis was to determine the potential effects of pumping on surface-water features such as ponds, streams, and wetlands in the BRMA and to determine whether field methods such as aquifer tests would be sufficient to adequately assess the potential effects of pumping on surface waters in this aquifer system. A better understanding of the water availability in this area was needed to fully assess these effects. Two processes that affect water

Table 4. Model-calculated water-level declines at the priority wetland sites in response to continuous pumping at aquifer test sites WGW443 and WGW444 for short-term (5 days) and average monthly conditions, Big River Management Area, central Rhode Island.

[Postive value indicates water-level decline from no-pumping condition.]

\begin{tabular}{|c|c|c|c|c|c|}
\hline \multirow{2}{*}{ Wetland name } & \multirow{2}{*}{ Well name } & B.I. ${ }^{1}-5$ days & B. $0 .^{2}-5$ days & August & Decembe \\
\hline & & (feet) & (feet) & (feet) & (feet) \\
\hline Bear Brook Swamp & COW484 & 0 & 0 & 0.2 & 0.2 \\
\hline Scarborough Swamp & WGW426 & 0 & 0 & 0 & 0.1 \\
\hline Reynolds Swamp & WGW427 & 0.1 & 0.1 & 3.8 & 5.8 \\
\hline Cedar Swamp & WGW428 & 0.2 & 0.2 & 0.4 & 0.5 \\
\hline Congdon Swamp & WGW429 & 0 & 0 & 0 & 0 \\
\hline
\end{tabular}

${ }^{1}$ B.I. is the condition in which the control boards were in place creating the reservoir; condition that occurs typically from March through October.

${ }^{2}$ B.O. is the condition in which the control boards were removed and the reservoir drained for weed control; acondition that occurs typically from November through February. 
availability in this area are the interaction between the till uplands and the valley-fill aquifer system and the interaction between the reservoir area of the Big River and the underlying groundwater system.

Because more than half (about 60 percent) of the recharge that enters this valley-fill aquifer system is estimated to be derived from inflow from the surrounding upland till areas (fig. 6), an understanding of how much water is available in these upland areas and of the timing of the release of this water into the adjacent aquifer system is needed to fully assess water availability in the BRMA. To date, flow rates from the uplands and how best to account for upland flow in numerical simulations are not very well understood.

The representation of the upland till areas in the groundwater model was based on the previous analysis conducted by Granato and other (2003) and has been a common approach to numerically represent these features in valley-fill aquifer systems in Rhode Island (Dickerman and Ozbilgin, 1985; Dickerman and others, 1990; Dickerman and Bell, 1993; Dickerman and others, 1997; Barlow and Dickerman, 2001; Friesz and Stone, 2007; Friesz, 2010). This approach has included removing the upland till region from the active model area and accounting for the flow from these areas as specified rates of streamflow for streams that drain upland areas or as specified recharge rates in the undrained areas of the uplands.

The total flux of the water specified along the contact between the uplands and the stratified glacial deposits for the undrained upland areas was based on a similar recharge rate as the valley-fill system on an annual basis but was adjusted on a monthly basis to account for possible changes in the timing of the movement of groundwater from the till deposits to the aquifer, referred to as the "release of water from storage". The adjustment made to the timing of the release of water from storage in the till areas was based on the distribution of monthly flow in gaged streams in nearby till areas as described in Granato and others (2003). This method was used because the water released from storage in the till deposits could not be explicitly represented in the model simulations given the boundary conditions used in this analysis.

Results from this analysis, as shown by the match between model-calculated and estimated water levels and streamflows (figs. 11-12), indicate that the total amount of recharge entering the aquifer from the till areas and the method of implicitly accounting for the change in the timing of water released from storage from the till areas appears adequate for this analysis on a monthly time scale. An exception to this includes the southern part of the BRMA where the model appears to be underrepresenting the release of water from upland storage (WGW285, fig. 11A) or not properly accounting for the timing of the release of water from storage in these areas (WGW28, fig. 11B).

Another instance of where the release of water from storage in the uplands may not be properly accounted for in the model simulations is the analysis of the change in water levels during the 5-day aquifer test. A comparison of the model-calculated water levels to those measured after 5 days of pumping during the aquifer test conducted in December 2009 indicates that differences between measured and modelcalculated water levels improve with distance from the pumped wells except for the area along upland till contact at observation well WGW427 (fig. 16F).

The model overprediction of water-level declines at this monitoring well may be a function of the inability of the model to accurately represent the effects of water released from storage in the till deposits on a less than monthly time scale. In order to account for this, the storage coefficient values simulated in the stratified glacial deposits along the no-flow boundary representing the contact between the uplands and the valley-fill deposits were increased by four orders of magnitude (from 0.00001 to 0.1 ) in the areas where till deposits exceed $20-\mathrm{ft}$ in thickness.

Increasing the amount of storage along the no-flow boundary resulted in a dampening of the water-level declines in this area indicating there may be a local-scale hydrogeologic condition not properly accounted for in the model. This change in storage coefficient did not appear to affect simulated water-level declines in the other observation wells located away from the upland contact, suggesting this storage effect may be a local one and needs to be considered when evaluating potential effects of pumping on wetlands located near the till upland areas. However, given the current understanding of the groundwater and surface-water interactions between till uplands and valley-fill sediments, it is not possible to quantify the amount of uncertainty this interaction adds to this analysis.

An additional process that may warrant further analysis is the interaction between the reservoir part of the Big River and the underlying groundwater system and, more specifically, the extent to which the reservoir may serve as a potential source of water to pumped wells in the BRMA through the process of induced infiltration. For the purpose of this analysis, the reservoir bottom sediments were assumed to have a uniform vertical leakance of $0.1 \mathrm{ft} / \mathrm{d}$. This value was increased by an order of magnitude to determine whether a better connection between the reservoir and the underlying aquifer would decrease the amount of simulated drawdowns observed as part of this analysis for pumping under long-term average monthly conditions. Results showed little change in water levels, for the 5-day aquifer-test period and for the long-term monthly conditions, indicating that the reservoir bottom sediments do not appear to have a substantial effect on limiting the interaction between groundwater and surface water in this aquifer system.

Additional simulations were made to determine the importance of the permeability of the glaciolacustrine deposits that underlie the reservoir bottom sediments (cross section $A-A^{\prime}$ (fig. 7A) on the interaction between groundwater and surface water in this area. An increase from $10 \mathrm{ft} / \mathrm{d}$ to $100 \mathrm{ft} / \mathrm{d}$ in the horizontal hydraulic conductivity value simulated in the model for these glaciolacustrine deposits resulted in a reduction in the simulated drawdown by as much as $3 \mathrm{ft}$ in 
the vicinity of the pumping wells. This reduction indicates if these sediments were simulated as being more permeable there would be more connection between the surface waters and the pumped wells, thus underscoring the importance of these sediments on the interaction between groundwater and surface water in this area.

Although the simulated drawdowns appear to be less with the simulation of more permeable glaciolacustrine deposits, the matches between measured and model-calculated water levels for the 5-day aquifer test were unacceptable for this simulated condition, indicating that the assumption of a more permeable glaciolacustrine deposit underlying the reservoir is not likely. Further examination of the distribution and extent of these sediments beneath the reservoir may be warranted to better understand the hydrogeologic control these sediments may have on changes in water levels in response to proposed groundwater withdrawals in this area.

Finally, the use of numerical models to simulate groundwater flow systems such as that of the BRMA has inherent limitations. Proper model design and calibration can help reduce these limitations; however, it is important to note that numerical simulations such as the ones detailed in this report are simplified representations of real-world conditions and only are designed for the purpose of helping better understand complex hydrogeologic conditions.

\section{Summary and Conclusions}

The Rhode Island Water Resources Board (RIWRB) is responsible for developing and protecting the State's water resources. In order to address ongoing concerns that increasing demand may exceed current capacity, the RIWRB has been exploring the largely untapped groundwater resources of the Big River Management Area (BRMA), an area that has been under consideration for development as a surface-water reservoir since the early 1960s. To date (2012), the U.S. Environmental Protection Agency has not given final approval for construction of this reservoir.

Since 1995, the U.S. Geological Survey (USGS), in cooperation with the RIWRB, has been conducting a series of scientific investigations of the water resources of the BRMA. These investigations were designed to improve the understanding of the hydrogeologic conditions of the area and the potential effects of groundwater withdrawals on streamflow in the area. The most recent of these investigations began in 2008 in response to a need for an assessment of the potential effects of pumping on wetlands in the BRMA. To address this need, a partnership was formed among the RIWRB, the USGS, and the University of Rhode Island (URI) with the goal of developing methods for characterizing wetland vegetation, soils, and hydrology, and monitoring and modeling water levels for pre- and post-watersupply development.
As part of this analysis, a groundwater-flow model was developed to assess the effects of proposed groundwater withdrawals on wetland water levels in the BRMA. The groundwater-flow model used for this analysis was developed as a subregional model of the larger model developed by Granato and others (2003) to focus only on the BRMA and, in particular, on the area in the northern part of the BRMA near the Flat River Reservoir. Test sites in this area were selected, in part, because of the assumption that if water were withdrawn from these sites, it most likely would be derived from induced infiltration from the flooded reservoir area of the Big River, and, therefore, groundwater withdrawals in this area would have less of an impact on surrounding wetlands and streamflow.

The model was calibrated to long-term average water levels, and streamflows estimated by the maintenance of variance type 1 (MOVE.1) analysis are documented in the appendix. The model then was used to calculate the change in water levels for 5 days of continuous pumping for conditions when the reservoir area is flooded, when the reservoir area is drained, and for conditions in which pumping rates are constant for average monthly recharge conditions in December when the reservoir area is typically drained and in August when the reservoir area is typically flooded. The model also was used to determine the sources of water to the pumped wells for these varying conditions and to assess how the sources of water to the pumped wells change with increasing pump times.

Results of the model simulations indicated that after 5 days of continuous pumping, the resulting declines in water levels in the nearby wetlands were typically less than 1 foot $(\mathrm{ft})$, and this change in water level did not appear to differ much between the condition when the reservoir area was flooded or drained. In both instances, most (63-64 percent) of the water pumped from the wells was derived from aquifer storage. In the scenario in which the reservoir area was flooded, the remaining sources of water included (1) induced infiltration from the reservoir (22 percent), (2) reduction in discharge to nearby streams (9 percent), and (3) reduction in groundwater discharge to the reservoir (6 percent). In the scenario in which the reservoir area was drained, the remaining sources of water included (1) reduction in groundwater discharge to the reservoir (24 percent), (2) induced infiltration from the Big River in the area of the drained reservoir (8 percent), and (3) reduction in discharge to nearby streams (4 percent).

Results of the model simulations indicated that for continuous pumping for long-term average monthly recharge conditions, the resulting declines in water levels near the pumping wells of about 5 to $6 \mathrm{ft}$. These changes in water levels were on average about $1 \mathrm{ft}$ greater when the reservoir area was drained compared to when the area was flooded.

The differences in water-level declines and the sources of water to the pumped wells varied with time and were dependent on whether the reservoir area was drained or flooded. In the scenario in which the reservoir area was 
flooded, more than half ( 52 percent) of the water withdrawn from the wells was derived from induced infiltration from the reservoir, while the remaining sources of water included (1) reduction in discharge to nearby streams (28 percent), (2) aquifer storage (13 percent), and (3) reduction in groundwater discharge to the reservoir (7 percent). In the scenario where the reservoir area was drained, most (64 percent) of the water pumped from the wells was derived from reduction in groundwater discharge to the reservoir area, while the remaining sources of water included reduction in discharge to nearby streams ( 29 percent) and induced infiltration from the Big River in the area of the drained reservoir (7 percent).

The analysis of the potential effects of groundwater withdrawals on wetlands in the BRMA indicates that given the hydrogeologic conditions of this aquifer system, a 5-day aquifer test may not be sufficient to adequately determine the effects of pumping on water levels in nearby wetlands. Model simulations showed that water levels continued to decline beneath the Reynolds Swamp wetland by an additional 4 to $6 \mathrm{ft}$, depending on whether the reservoir area was flooded or drained, as pumping times were increased from a 5-day simulation period to a simulation period representative of long-term average monthly conditions, which would be more indicative of how the wells would be utilized as a source of public-water supply.

The primary reason for the continued decline in water levels with increased pumping time is related to the shift from the primary source of water to the pumped wells being derived from aquifer storage during the early-time (5 days) simulation to being derived from induced infiltration from the reservoir or captured groundwater discharge to the Big River in the reservoir area, as was the case for the long-term monthly conditions simulated for December and August. Additional testing for a longer period of time and a more detailed characterization of geologic framework and the interaction between the till uplands and stratified glacial deposits may be required to fully assess the effects of pumping on surfacewater features in this aquifer system.

\section{References Cited}

Alley, W.M., Reilly, T.E., and Franke, O.L., 1999, Sustainability of ground-water resources: U.S. Geological Survey Circular 1186, 79 p.

Anderson, M.P., and Woessner, W.W., 1992, Applied groundwater modeling: San Diego, Calif., Academic Press, Inc., $381 \mathrm{p}$.

Barlow, P.M., and Dickerman, D.C., 2001, Numericalsimulation and conjunctive-management models of the Hunt-Annaquatucket-Pettaquamscutt stream-aquifer system, Rhode Island: U.S. Geological Survey Professional Paper $1636,88 \mathrm{p}$.
Boothroyd, J.C., Freedman, J.H., Brenner, H.B., and Stone, J.R., 1998, The glacial geology of southern Rhode Island, in Murray, D.P., ed., New England Intercollegiate Geological Conference, 90th annual meeting, Kingston, R.I., October 9-11, 1998, Guidebook for fieldtrips in Rhode Island and adjacent regions of Connecticut and Massachusetts: trip C5, $25 \mathrm{p}$.

Borenstein, M.S., Golet, F.C., Armstrong, D.S., Breault, R.F., McCobb, T.D., and Weiskel, P.K., 2012, Hydrologic, vegetation, and soils data collected in selected wetlands of the Big River Water Management Area, Rhode Island: U.S. Geological Survey Data Series 666, 101 p.

Carlson, C.S., and Lyford, F.P., 2005, Simulated ground-water flow for a pond-dominated aquifer system near Great Sandy Bottom Pond, Pembroke, Massachusetts: U.S. Geological Survey Scientific Investigations Report 2004-5269, 43 p.

Chow, V.T., 1964, Handbook of applied hydrology: New York, McGraw-Hill, [variously paged].

Craft, P.A., 2001, Hydrogeologic data for the Big RiverMishnock River stream-aquifer system, central Rhode Island: U.S. Geological Survey Open-File Report 01-250, $104 \mathrm{p}$.

Dickerman, D.C., and Bell, R.W., 1993, Hydrogeology, water quality, and ground-water-development alternatives in the upper Wood River ground-water reservoir, Rhode Island: U.S. Geological Survey Water-Resources Investigations Report 92-4119, 87 p.

Dickerman, D.C., Kliever, J.D., and Stone, J.R., 1997, Hydrogeology, water quality, and simulation of groundwater-development alternatives in the UsquepaugQueen ground-water reservoir, southern Rhode Island: U.S. Geological Survey Water-Resources Investigations Report 97-4126, $48 \mathrm{p}$.

Dickerman, D.C., and Ozbilgin, M.M., 1985, Hydrogeology, water quality, and ground-water development alternatives in the Beaver-Pasquiset ground-water reservoir, Rhode Island: U.S. Geological Survey Water-Resources Investigations Report 85-4190, 104 p.

Dickerman, D.C., Trench, E.C.T., and Russell, J.P., 1990, Hydrogeology, water quality, and ground-water development alternatives in the lower Wood River groundwater reservoir, Rhode Island: U.S. Geological Survey Water-Resources Investigations Report 89-4031, $109 \mathrm{p}$.

Farnsworth, R.K., Thompson, E.S., and Peck, E.L., 1982, Evaporation atlas for the contiguous 48 states: National Oceanic and Atmospheric Administration Technical Report NWS 33, 26 p. 
Feininger, T.G., 1962, Surficial geology of the Hope Valley quadrangle, Rhode Island: U.S. Geological Survey Geologic Quadrangle GQ-166, scale 1:24,000.

Friesz, P.J., 2010, Delineation and prediction uncertainty of areas contributing recharge to selected well fields in wetland and coastal settings, southern Rhode Island: U.S. Geological Survey Scientific Investigations Report 2010-5060, 69 p.

Friesz, P.J., and Stone, J.R., 2007, Simulation of ground-water flow and areas contributing recharge to production wells in contrasting glacial valley-fill settings, Rhode Island: U.S. Geological Survey Scientific Investigations Report 2007-5133, $50 \mathrm{p}$.

Granato, G.E., 2009, Streamflow Record Extension Facilitator (SREF version 1.0)-A program for extending and augmenting available streamflow data using longterm streamflow records from hydrologically similar sites, appendix 3 in Computer programs for obtaining and analyzing daily mean streamflow data from the U.S. Geological Survey National Water Information System Web site: U.S. Geological Survey Open-File Report 2008-1362, 123 p. on CD-ROM.

Granato, G.E., and Barlow, P.M., 2005, Effects of alternative instream-flow criteria and water-supply demands on ground-water development options in the Big River Area, Rhode Island: U.S. Geological Survey Scientific Investigations Report 2004-5301, 110 p.

Granato, G.E., Barlow, P.M., and Dickerman, D.C., 2003, Hydrogeology and simulated effects of ground-water withdrawals in the Big River Area, Rhode Island: U.S. Geological Survey Water-Resources Investigations Report 03-4222, $76 \mathrm{p}$.

Harbaugh, A.W., 2005, MODFLOW-2005-The U.S. Geological Survey modular ground-water model - the ground-water flow process: U.S. Geological Survey Techniques and Methods 6-A16, variously paged.

Hemond, H.F., 1980, Biogeochemistry of Thoreau's bog, Concord, Massachusetts: Ecological Monographs, v. 50, no. 4 , p. 507-526.

Jensen, M.E., and Haise, H.D., 1963, Estimating evapotranspiration from solar radiation: Journal of Irrigation and Drainage, v. 89, no. IR4, p. 15-41.

Konikow, L.F., and Reilly, T.E., 1999, Groundwater modeling, in Delleur, J.W., ed., The handbook of groundwater engineering: Boca Raton, Fla., CRC Press, 40 p.

Lyford, F.P., Carlson, C.S. and Hansen, B.P., 2003, Delineation of water sources for public-supply wells in three fracturedbedrock aquifer systems in Massachusetts: U.S. Geological Survey Water-Resources Investigations Report 02-4290, $114 \mathrm{p}$.
Masterson, J.P., 2011, Simulated effects of water withdrawals on groundwater flow (MODFLOW models), part 3 of Bent, G.C., Zarriello, P.J., Granato, G.E., Masterson, J.P., Walter, D.A., Waite, A.M., and Church, P.E., Simulated effects of water withdrawals and land-use changes on streamflows and groundwater levels in the Pawcatuck River Basin, southwestern Rhode Island and southeastern Connecticut: U.S. Geological Survey Scientific Investigations Report 2009-5127, $254 \mathrm{p}$.

Masterson, J.P., Sorenson, J.R., Stone, J.R., Moran, S.B., and Hougham, Andrea, 2007, Hydrogeology and simulated ground-water flow in the Salt Pond region of southern Rhode Island: U.S. Geological Survey Scientific Investigations Report 2006-5271, 56 p.

McDonald, M.G., and Harbaugh, A.W., 1988, A modular three-dimensional finite-difference ground-water flow model: U.S. Geological Survey Techniques of WaterResources Investigations, book 6, chap. A1, 586 p.

Mortellaro, S., Krupa, S., Fink, L., and Van Horn, J., 1995, Literature review on the effects of groundwater drawdown on isolated wetlands: West Palm Beach, Fla., South Florida Water Management District Technical Publication No. 96-01, $44 \mathrm{p}$.

National Oceanic and Atmospheric Administration, 2007, accessed March 21, 2007, at http://www.cdo.ncdc.noaa.gov/ dly/DLY.

Niswonger, R.G., and Prudic, D.E., 2005, Documentation of the Streamflow-Routing (SFR2) package to include unsaturated flow beneath streams-A modification to SFR1: U.S. Geological Survey Techniques and Methods book 6, chap. A13, 50 p.

Power, W.R., Jr., 1957, Surficial geology of the Slocum quadrangle, Rhode Island: U.S. Geological Survey Geologic Quadrangle GQ-106, scale 1:31,680.

Reilly, T.E., 2001, System and boundary conceptualization in ground-water flow simulation: U.S. Geological Survey Techniques of Water-Resources Investigations, book 3, chap. B8, $38 \mathrm{p}$.

Reilly, T.E., and Harbaugh, A.W., 2004, Guidelines for evaluating ground-water flow models: U.S. Geological Survey Scientific Investigations Report 2004-5038, 30 p.

Rochow, T.F., and Rhinesmith P., 1991, Comparative analysis of biological conditions in five cypress dome wetlands at the Starkey and Eldridge-Wilde well fields in southwest Florida: Brooksville, Fla., Southwest Florida Water Management District Technical Report 1991-1, 67 p.

Skidds, D.E., and Golet. F.C., 2005, Estimating hydroperiod suitability for breeding amphibians in southern Rhode Island seasonal forest ponds: Wetlands Ecology and Management, v. 13, p. 349-366. 
Smith, J.H., 1956, Surficial geology of the Crompton quadrangle, Rhode Island: U.S. Geological Survey Geologic Quadrangle GQ-94, scale 1:31,680.

Sonenshein, R.S., and Hofstetter, R.H., 1990, Hydrologic effects of well-field operations in a wetland, Dade County, Florida: U.S. Geological Survey Water-Resources Investigations Report 90-4143, 59 p.

Stone, B.D., and Borns, H.W., Jr., 1986, Pleistocene glacial and interglacial stratigraphy of New England, Long Island, and adjacent George's Bank and Gulf of Maine, in Sibrava, V., Bowen, D.Q., and Richmond, G.M., eds., Quaternary glaciations in the northern hemisphere: Oxford, Pergamon Press, p. 39-52.
Stone, J.R., and Dickerman, D.C., 2002, Glacial geology and aquifer characteristics of the Big River area, central Rhode Island: U.S. Geological Survey Water-Resources Investigations Report 01-4169, 12 p.

Wilmott, C.J., 1977, WATBUG-A fortran IV algorithm for calculating the climatic water budget: Climatology, v. 30, p. 2-4.

Zarriello, P.J., and Bent, G.C., 2004, A precipitation-runoff model for the analysis of the effects of water withdrawals and land-use change on streamflow in the UsquepaugQueen River Basin, Rhode Island: U.S. Geological Survey Scientific Investigations Report 2004-5139, 86 p. 
This page has been left blank intentionally. 


\section{Appendix 1. Methods for Estimating Long-Term Hydrologic Conditions}

\section{Contents}

Methods for Estimating Long-Term Hydrologic Conditions ...........................................................4

Estimates of Long-Term Average Groundwater Level Altitudes in the Big River Area...........46

Estimates of Long-Term Average Streamflows in the Big River Area ....................................47

References Cited................................................................................................................

\section{Figures}

1-1. Example MOVE.1 regression line predicting groundwater-level altitudes at project well WGW305 from groundwater-level altitudes at index well SNW6. Results for average-monthly values from 1960 through 2006 also are shown.

1-2. Example MOVE.1 regression line predicting streamflows at streamgage 01115800

Big River at Route 3 near Nooseneck, Rhode Island, and from streamflows at streamgage 01118000 Wood River at Hope Valley, R.I. Results for monthly-average values from 1960 through 2006 also are shown.

1-3. Boxplot showing long-term variations in annual-average and monthly-average groundwater-level altitudes in long-term index well SNW 6 from 1960 through 2006...50

1-4. Boxplot showing long-term variations in annual-average and monthly-average streamflows at streamgage 01118000 Wood River at Hope Valley, Rhode Island, from 1960 through 2006.

\section{Tables}

1-1. Correlation table between groundwater-level altitudes measured at U.S. Geological Survey long-term network wells, monitoring wells in the Big River Management Area, and pond levels recorded at Capwell Mill Pond.

1-2. MOVE.1 Regression statistics for monitoring wells in the Big River Management Area and Capwell Mill Pond developed using U.S. Geological Survey long-term network well data.

1-3. Average-monthly groundwater-level altitudes for U.S. Geological Survey longterm network wells from 1960 through 2006 and MOVE.1 regression estimates of groundwater-level altitudes for monitoring wells and Capwell Mill Pond in the Big River Management Area.

1-4. MOVE.1 regression statistics for short-term streamgages and partial-record stations in the Big River Management Area developed using streamflow data from the 1960-2009 period at U.S. Geological Survey streamgage 01118000 the Wood River at Hope Valley, Rhode Island. 


\section{Methods for Estimating Long-Term Hydrologic Conditions}

Long-term estimates of hydrologic conditions are needed to put short-term study results into a larger hydrologic context and to provide data for calibration of hydrologic simulation models. If no other data are available, it may take a decade or more to collect the data necessary to begin to represent hydrologic variability at a site of interest. However, long-term index data can be used with short-term data from the site of interest to estimate long-term values for that site. The U.S. Geological Survey, in cooperation with other State and Federal agencies, maintains an extensive network of streamgages and water-level monitoring wells. Data from this network can be used to estimate hydrologic conditions at a site of interest. There are several methods that are commonly used to estimate long-term hydrologic statistics with limited data; the maintenance of varance type 1 (MOVE.1) regression method was selected for this study (Hirsch, 1982; Hirsch and Gilroy, 1984; Ries and Friesz, 2000; Helsel and Hirsch, 2002; Granato, 2009).

The MOVE.1 regression method (also known as the line of organic correlation) is used to develop long-term data or statistics for a site of interest. Short-term data collected over a range of hydrologic conditions at the site of interest is used with concurrent data collected at one or more long-term index sites to develop one or more regression equations (Hirsch, 1982; Hirsch and Gilroy, 1984; Helsel and Hirsch, 2002; Granato, 2009). The fundamental regression equation is

$$
Y_{p i}=m X_{i}+b+e_{i}
$$

where

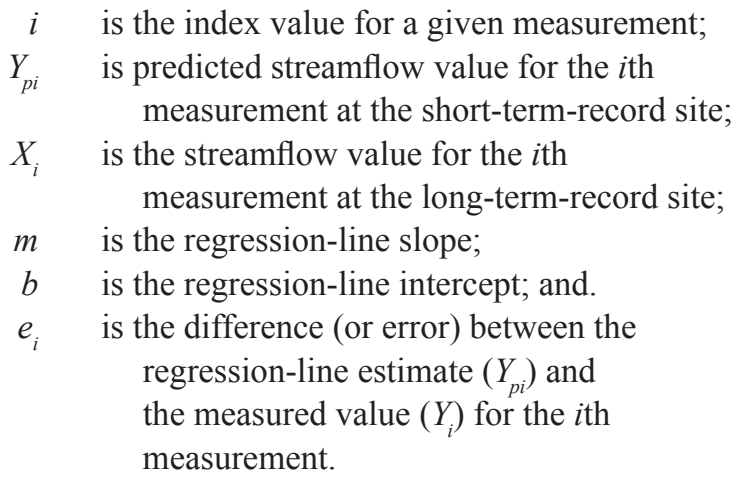

The slope $(m)$ of the MOVE. 1 regression line is calculated as the product of the sign of the correlation coefficient $(r)$ and the ratio of the standard deviation of the $Y$ values $\left(S_{y}\right)$ to the standard deviation of the concurrent $X$ values $\left(S_{x}\right)$, and is expressed mathematically as

$$
m=\operatorname{sign}[r]\left(\frac{S_{y}}{S_{x}}\right)
$$

Unlike ordinary least squares regression, the MOVE.1 approach preserves the variance of the predicted $Y$ population because the sign of the correlation coefficient is used rather than the magnitude of the correlation coefficient (Hirsch, 1982; Hirsch and Gilroy, 1984; Helsel and Hirsch, 2002; Granato, 2009).

The intercept $(b)$ of the MOVE.1 regression line is expressed mathematically as

$$
b=\bar{Y}-m \bar{X},
$$

where

$$
\begin{gathered}
\bar{X} \quad \begin{array}{l}
\text { is the average of concurrent values measured } \\
\text { at the index site; and }
\end{array} \\
\bar{Y} \quad \text { is the average of concurrent values measured } \\
\text { at the site of interest. }
\end{gathered}
$$

As such, the intercept is calculated so that the line with slope m passes through a point with $X_{i}$ and $Y_{i}$ coordinates that equal the mean of the $X$ and $Y$ populations, respectively (Helsel and Hirsch, 2002).

Once the regression equation is formulated, the quality of the fit can be evaluated using residual error statistics. The residual error (or uncertainty) in the predicted $Y_{p i}$ value for each $X, Y$ pair is expressed mathematically as

$$
e_{i}=Y_{i}-\left(m X_{i}+b\right)
$$

Statistics of the residuals can be used to determine the goodness of fit and to estimate prediction-interval uncertainties (Hirsch, 1982; Hirsch and Gilroy, 1984).

Figure 1-1 is an example of a MOVE.1 regression line calculated using measured groundwater-level-altitude data in two wells. Concurrent monthly groundwater-levelaltitude measurements are paired and are used to estimate the coefficients of the regression line. In this case, 24 concurrent monthly groundwater measurements from USGS network well SNW6 and Big River Management Area (BRMA) well RI-WGW 305 were used to define the MOVE.1 regression line.

Once the regression line is established, it can be used to estimate groundwater-level altitudes in the BRMA from altitudes in the index well. For example, figure 1-1 shows estimates of long-term average-monthly groundwater-level altitudes in well WGW305 that are estimated using statistics from USGS network well SNW6. These values fall on the line because the MOVE.1 regression estimate is the most probable value of the corresponding value for well WGW305 


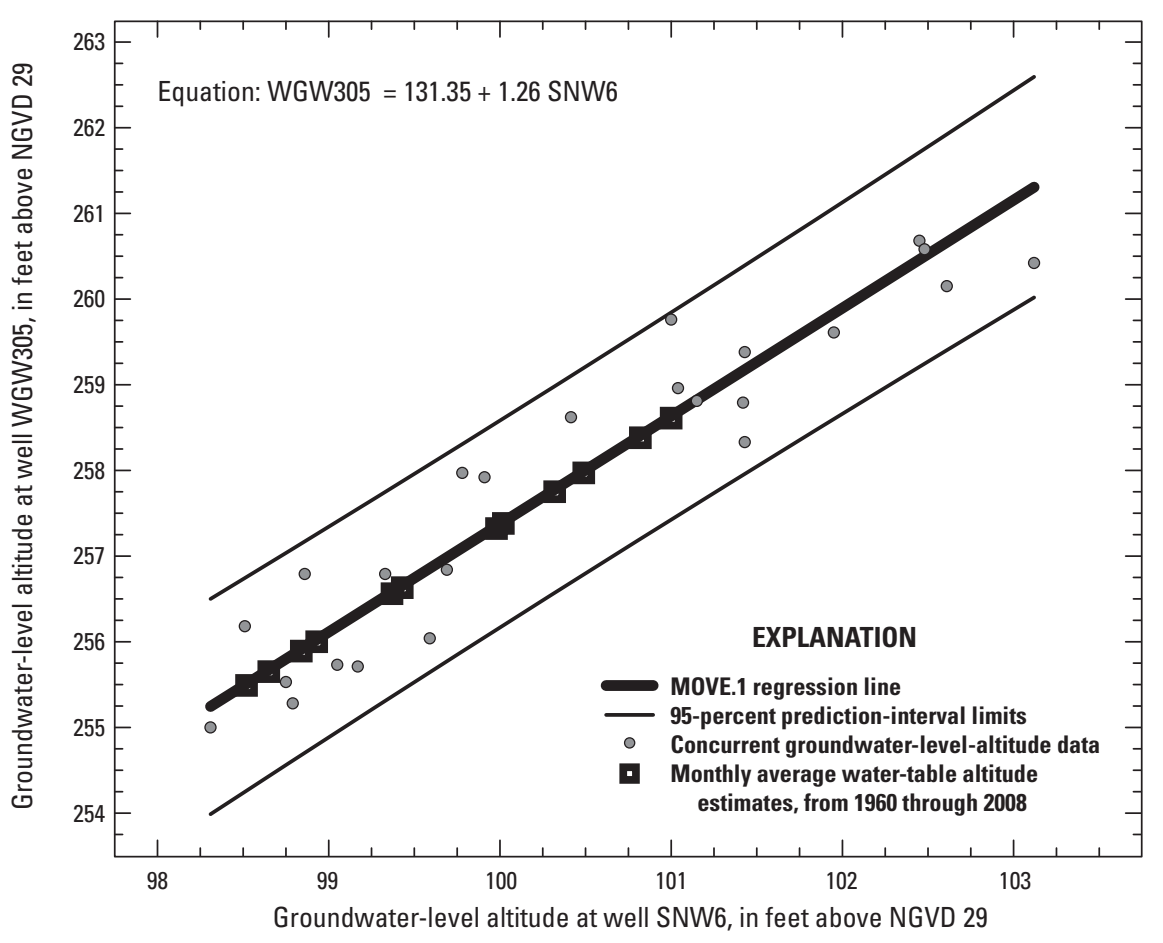

Figure 1-1. Example MOVE.1 regression line predicting groundwater-level altitudes at project well WGW305 from groundwater-level altitudes at index well SNW6. Results for average-monthly values from 1960 through 2006 also are shown.

Random variations in paired measurements used to construct the regression line are evident by the considerable scatter around the regression line on the figure. The regression line provides the expected value, but actual values may vary. The 95 -percent prediction intervals on figure 1-1 are calculated using the residual statistics from available data. It is inferred that there is a 95-percent chance that the actual long-term average-monthly groundwater-level altitude in well WGW305 would be within the region between the confidence intervals. For example, the lowest long-term average-monthly groundwater-level altitude in well SNW6 for the period 1960-2006 is 98.52 feet above NGVD 29. The corresponding MOVE.1 estimate for well WGW305 is 255.49 feet above NGVD 29, and there is a 95-percent chance that the actual value (if it were available) would be in the range 254.24 to $256.74 \mathrm{ft}$ above NGVD 29.

MOVE.1 regression analysis of streamflow data uses the common (base 10) logarithms of streamflow because logarithmic transformation commonly helps linearize relations between streamflows collected at different stations and improves the structure of residuals (Ries and Friesz, 2000; Helsel and Hirsch, 2002; Granato and others, 2003; Granato, 2009). Figure $1-2$ is an example of a MOVE. 1 regression line calculated using the logarithms of streamflow data measured at streamgages on the Wood River and the Big River. As with the previous example, figure 1-2 shows the data, the regression line, the 95-percent confidence limits, and the average-monthly estimates from 1960 through 2006. There are two far outliers (one on January 17, 1995, and the other on December 12, 2008) that are beyond the 95-percent confidence limits of the data (fig. 1-2). These values, which are stormflow measurements, occur because of differences between the instantaneous measurements at the Big River streamgage and the mean-daily streamflows reported for the Wood River streamgage. These two data points, however, were not removed from the data used to formulate the regression model because they reflect measurement conditions and do not inordinately affect the estimate of the slope or the intercept as indicated by the good fit to the rest of the data in figure 1-2. 


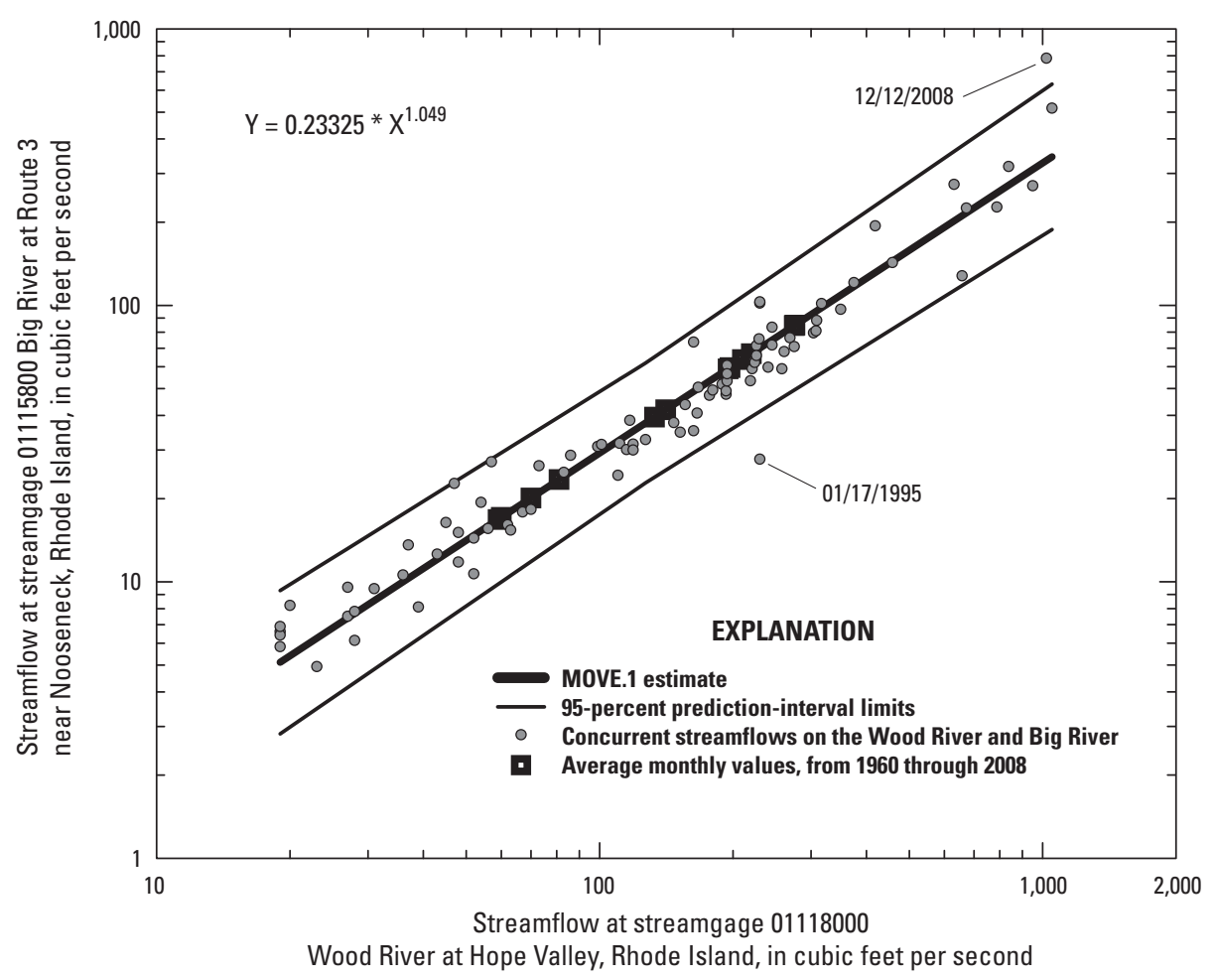

Figure 1-2. Example MOVE.1 regression line predicting streamflows at streamgage 01115800 Big River at Route 3 near Nooseneck, Rhode Island, and from streamflows at streamgage 01118000 Wood River at Hope Valley, R.I. Results for monthly-average values from 1960 through 2006 also are shown.

\section{Estimates of Long-Term Average Groundwater- Level Altitudes in the Big River Area}

MOVE.1 was used to estimate average monthly groundwater-level altitudes for 12 wells and 1 pond (Capwell Mill Pond) in the BRMA for the period 1960 through 2006 Index wells COW411, EXW6, and SNW6 were evaluated for use. Correlations between groundwater-level-altitude measurements in these wells and in wells in the BRMA are relatively strong. Correlations are greater than 0.61 for all well pairs and greater than 0.79 for the selected (best fit) well pairs (table 1-1). Well SNW6 was the best fit for nine wells and well EXW6 was the best fit for three wells and for Capwell Mill Pond. As such, these two index wells were selected to represent long-term conditions in the BRMA. The highlighted MOVE. 1 regression equations in table 1-2 were used to estimate the long-term average-annual and average-monthly groundwater-level altitudes in feet above NVGD 1929 for the period 1960-2006, which are listed in table 1-3. The median 95-percent prediction intervals in table 1-2 provide an uncertainty range for the estimated groundwater-level altitudes in table 1-3. For example, the estimated annual-average groundwater-level altitude during
1960-2006 at well WGW285 (264.48 ft) was estimated from the estimated annual-average value for EXW6 during the same period (127.09 ft) using equation 2 in table $1-2$. The 95-percent prediction interval for the MOVE.1 regression equation is about $0.82 \mathrm{ft}$; therefore, it is expected, based on analysis of available data, that there is a 95-percent chance that the actual annual-average groundwater-level altitude at well WGW285 is in the range from 263.66 to $265.30 \mathrm{ft}$. The magnitude of uncertainty represented in the MOVE. 1 prediction interval is similar to variations in the long-term record. Data from long-term index wells indicate substantial variations in the average-annual and monthly groundwaterlevel altitudes during the period of record. At index well SNW6, the total range in individual measurements is about $7 \mathrm{ft}$, the range of measurements within individual months is about $5 \mathrm{ft}$, the range in annual-average values is about $3 \mathrm{ft}$, and the range in average-monthly values is about $2.5 \mathrm{ft}$ (fig. 1-3). Groundwater-level altitude variations at other locations may be different from the ones shown because the variations depend on the hydrogeology at the screened interval of the observation well and the topographic setting, which indicates the position of the well in the hydrologic system (Frimpter, 1981; Socolow and others, 1994; Granato and others, 2003). 
Table 1-1. Correlation table between groundwater-level altitudes measured at U.S. Geological Survey (USGS) long-term network wells, monitoring wells in the Big River Management Area, and pond levels recorded at Capwell Mill Pond.

[Table shows Pearson's r correlation coefficients, which are unitless; the shaded correlation coefficients were selected as the best alternative for estimating water levels in the associated well in the Big River Management Area]

\begin{tabular}{lccc}
\hline \multirow{2}{*}{$\begin{array}{c}\text { Big River } \\
\text { wells or pond }\end{array}$} & \multicolumn{3}{c}{$\begin{array}{c}\text { Correleations coefficients (unitless) with data from } \\
\text { USGS long-term network wells }\end{array}$} \\
\cline { 2 - 4 } & COW411 & EXW6 & SNW6 \\
\hline WGW285 & 0.781 & 0.806 & 0.752 \\
WGW286 & 0.801 & 0.702 & 0.888 \\
WGW87 & 0.887 & 0.793 & 0.932 \\
WGW290 & 0.883 & 0.775 & 0.917 \\
WGW291 & 0.934 & 0.916 & 0.935 \\
WGW293 & 0.907 & 0.892 & 0.912 \\
WGW294 & 0.702 & 0.809 & 0.707 \\
WGW303 & 0.737 & 0.612 & 0.797 \\
WGW304 & 0.859 & 0.784 & 0.935 \\
WGW305 & 0.912 & 0.827 & 0.949 \\
WGW313 & 0.901 & 0.841 & 0.915 \\
WGW320 & 0.885 & 0.929 & 0.895 \\
Capwell Mill Pond & 0.913 & 0.939 & 0.913 \\
\hline
\end{tabular}

\section{Estimates of Long-Term Average Streamflows in the Big River Management Area}

MOVE.1 also was used to estimate long-term averagemonthly streamflow values from 1960 through 2006. Data from the long-term streamgage 01118000 on the Wood River at Hope Valley was selected to represent long-term conditions in the BRMA because correlations among streamflow measurements in these areas are very strong (greater than 0.91 ; table 1-4). This streamgage has a long, uninterrupted period of record from 1960 through 2006 and water use in the Wood River Basin is a small percentage of average-monthly streamflows (Zarriello, 2011).

The MOVE. 1 regression equations in table $1-4$ were developed using concurrent flow measurements from the 1960-2009 period to increase the amount of data available to develop the equations. However, statistics for streamflows measured from 1960 through 2006 at streamgage 01118000 were used to estimate the long-term average-annual and average-monthly streamflow values in cubic feet per second at selected locations in the Big River watershed for the modeling period (table 1-4). For example, the estimated annual-average streamflow during 1960-2009 in the Big River at Route 3 is estimated to be about $48.4 \mathrm{ft} 3 / \mathrm{s}$ (about $2.15 \mathrm{ft} 3 / \mathrm{s} / \mathrm{mi}^{2}$ ) using the equation in table 1-4. The logarithmic 95-percent prediction interval for this MOVE. 1 regression equation is 0.232 , which would yield an upper 95-percent prediction interval value of about 1.72 times the MOVE. 1 estimate and a lower 95 -percent prediction interval value of about 0.59 times the MOVE. 1 estimate. Therefore, based on analysis of available data, it is expected that there is a 95-percent chance that the actual annual-average flow rate in the Big River at Route 3 is in the range from 28.3 (about $1.26 \mathrm{ft} 3 / \mathrm{s} / \mathrm{mi}^{2}$ ) to $82.6 \mathrm{ft}^{3} / \mathrm{s}$ (about $3.67 \mathrm{ft}^{3} / \mathrm{s} / \mathrm{mi}^{2}$ ). In comparison, the annual-average streamflows at streamgage 01118000 the Wood River at Hope Valley ranged from 1.18 to $3.51 \mathrm{ft}^{3} / \mathrm{s} / \mathrm{mi}^{2}$ with an average value of $2.2 \mathrm{ft}^{3} / \mathrm{s} / \mathrm{mi}^{2}$ from 1960 through 2006 (fig. 1-4). 
Table 1-2. MOVE.1 regression statistics for monitoring wells in the Big River Management Area and Capwell Mill Pond developed using U.S. Geological Survey long-term network well data.

[MOVE.1, maintenance of variance type 1; RMSE, root mean square error; PI, 95-percent prediction interval width (median value); the shaded statistics were estimated using data from well EXW6, whereas the nonshaded statistics were estimated using data from well SNW6]

\begin{tabular}{|c|c|c|c|c|c|c|}
\hline \multirow{2}{*}{$\begin{array}{c}\text { Big River } \\
\text { wells or ponds }\end{array}$} & \multirow{2}{*}{$\begin{array}{l}\text { Network } \\
\text { well }\end{array}$} & \multirow{2}{*}{$\begin{array}{l}\text { Correlation } \\
\text { coefficient }\end{array}$} & \multicolumn{4}{|c|}{ MOVE.1 } \\
\hline & & & Slope & Intercept & RMSE & PI \\
\hline WGW285 & COW411 & 0.781 & 0.54701 & 134.05 & 0.18 & 0.869 \\
\hline WGW285 & EXW6 & 0.806 & 0.59517 & 188.84 & 0.16 & 0.819 \\
\hline WGW285 & SNW6 & 0.752 & 0.46264 & 218.21 & 0.204 & 0.922 \\
\hline WGW286 & COW411 & 0.801 & 1.10705 & 22.11 & 0.642 & 1.634 \\
\hline WGW286 & EXW6 & 0.702 & 1.17919 & 136.13 & 0.963 & 2.005 \\
\hline WGW286 & SNW6 & 0.888 & 0.95714 & 190.38 & 0.363 & 1.226 \\
\hline WGW287 & COW411 & 0.887 & 2.11561 & -231.34 & 1.459 & 2.477 \\
\hline WGW287 & EXW6 & 0.793 & 2.345 & -24.95 & 2.663 & 3.35 \\
\hline WGW287 & SNW6 & 0.932 & 1.78672 & 94.41 & 0.879 & 1.916 \\
\hline WGW290 & COW411 & 0.883 & 1.16583 & -15.13 & 0.445 & 1.365 \\
\hline WGW290 & EXW6 & 0.775 & 1.2786 & 100.33 & 0.859 & 1.896 \\
\hline WGW290 & SNW6 & 0.917 & 0.97865 & 164.96 & 0.317 & 1.151 \\
\hline WGW291 & COW411 & 0.934 & 0.61196 & 108.01 & 0.071 & 0.545 \\
\hline WGW291 & EXW6 & 0.916 & 0.66586 & 169.29 & 0.09 & 0.615 \\
\hline WGW291 & SNW6 & 0.935 & 0.51632 & 202.29 & 0.07 & 0.541 \\
\hline WGW293 & COW411 & 0.907 & 0.6338 & 101.05 & 0.102 & 0.654 \\
\hline WGW293 & EXW6 & 0.892 & 0.6804 & 165.67 & 0.118 & 0.705 \\
\hline WGW293 & SNW6 & 0.912 & 0.54203 & 197.97 & 0.097 & 0.636 \\
\hline WGW294 & COW411 & 0.702 & 0.76358 & 102.87 & 0.506 & 1.458 \\
\hline WGW294 & EXW6 & 0.809 & 0.82585 & 179.96 & 0.324 & 1.17 \\
\hline WGW294 & SNW6 & 0.707 & 0.64425 & 220.51 & 0.497 & 1.441 \\
\hline WGW303 & COW411 & 0.737 & 1.56851 & -115.87 & 1.799 & 2.746 \\
\hline WGW303 & EXW6 & 0.612 & 1.6951 & 42.69 & 2.656 & 3.341 \\
\hline WGW303 & SNW6 & 0.797 & 1.32477 & 125.63 & 1.388 & 2.404 \\
\hline WGW304 & COW411 & 0.859 & 2.20168 & -271.76 & 1.815 & 2.75 \\
\hline WGW304 & EXW6 & 0.784 & 2.3518 & -45.82 & 2.769 & 3.402 \\
\hline WGW304 & SNW6 & 0.935 & 1.87582 & 65.59 & 0.832 & 1.857 \\
\hline WGW305 & COW411 & 0.912 & 1.48857 & -97.57 & 0.604 & 1.605 \\
\hline WGW305 & EXW6 & 0.827 & 1.71176 & 39.68 & 1.185 & 2.242 \\
\hline WGW305 & SNW6 & 0.949 & 1.26025 & 131.35 & 0.352 & 1.222 \\
\hline WGW313 & COW411 & 0.901 & 0.97947 & 20.06 & 0.3 & 1.134 \\
\hline WGW313 & EXW6 & 0.841 & 1.10216 & 113.5 & 0.482 & 1.434 \\
\hline WGW313 & SNW6 & 0.915 & 0.8205 & 171.57 & 0.258 & 1.051 \\
\hline WGW320 & COW411 & 0.885 & 1.73911 & -150.28 & 1.124 & 2.214 \\
\hline WGW320 & EXW6 & 0.929 & 2.07801 & 0.47 & 0.69 & 1.737 \\
\hline WGW320 & SNW6 & 0.895 & 1.43175 & 121.29 & 1.023 & 2.111 \\
\hline Capwell Mill Pond & COW411 & 0.913 & 0.12086 & 227.22 & 0.005 & 0.145 \\
\hline Capwell Mill Pond & EXW6 & 0.939 & 0.14705 & 237.37 & 0.003 & 0.122 \\
\hline Capwell Mill Pond & SNW6 & 0.913 & 0.10068 & 245.98 & 0.005 & 0.146 \\
\hline
\end{tabular}




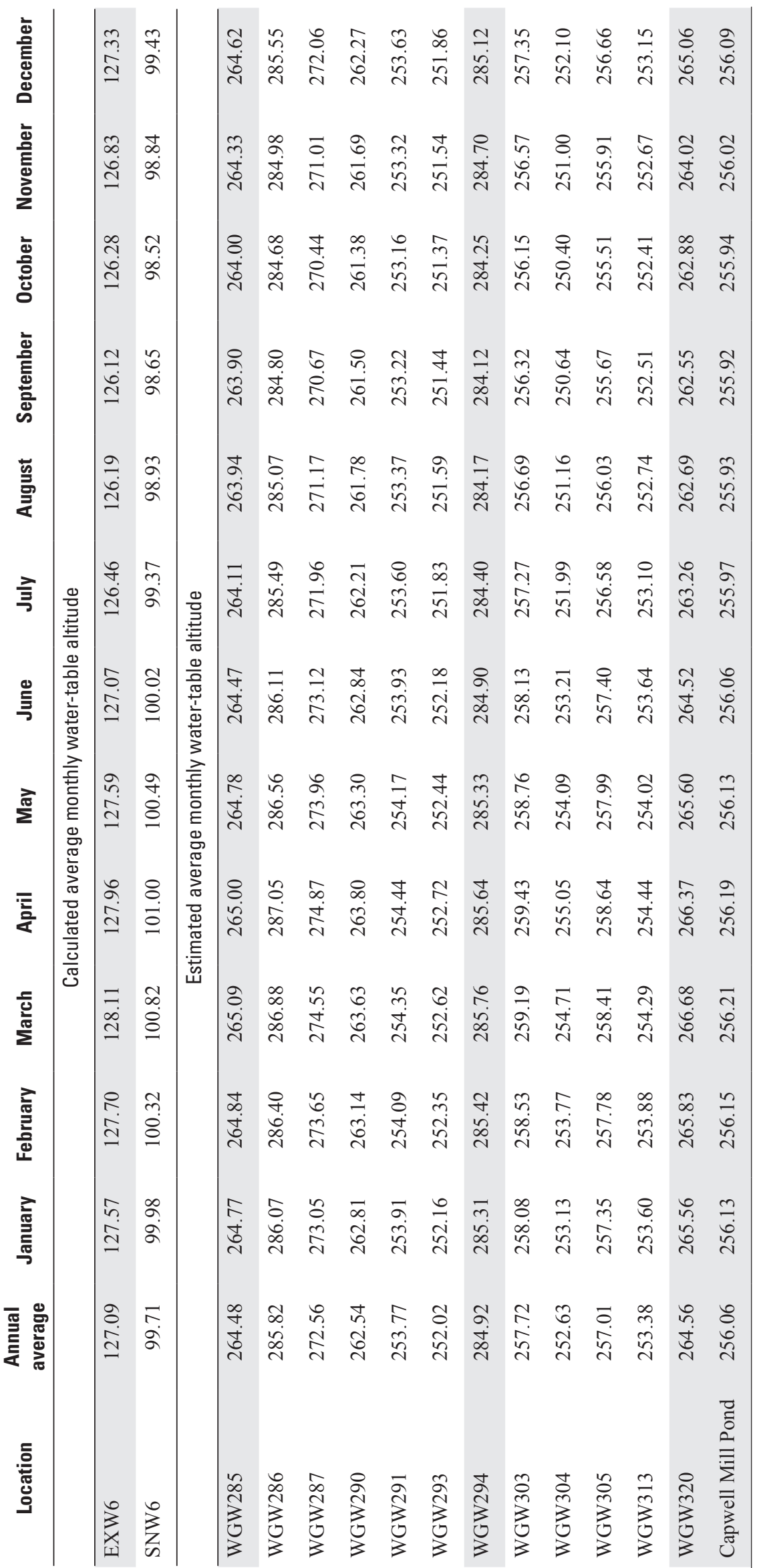




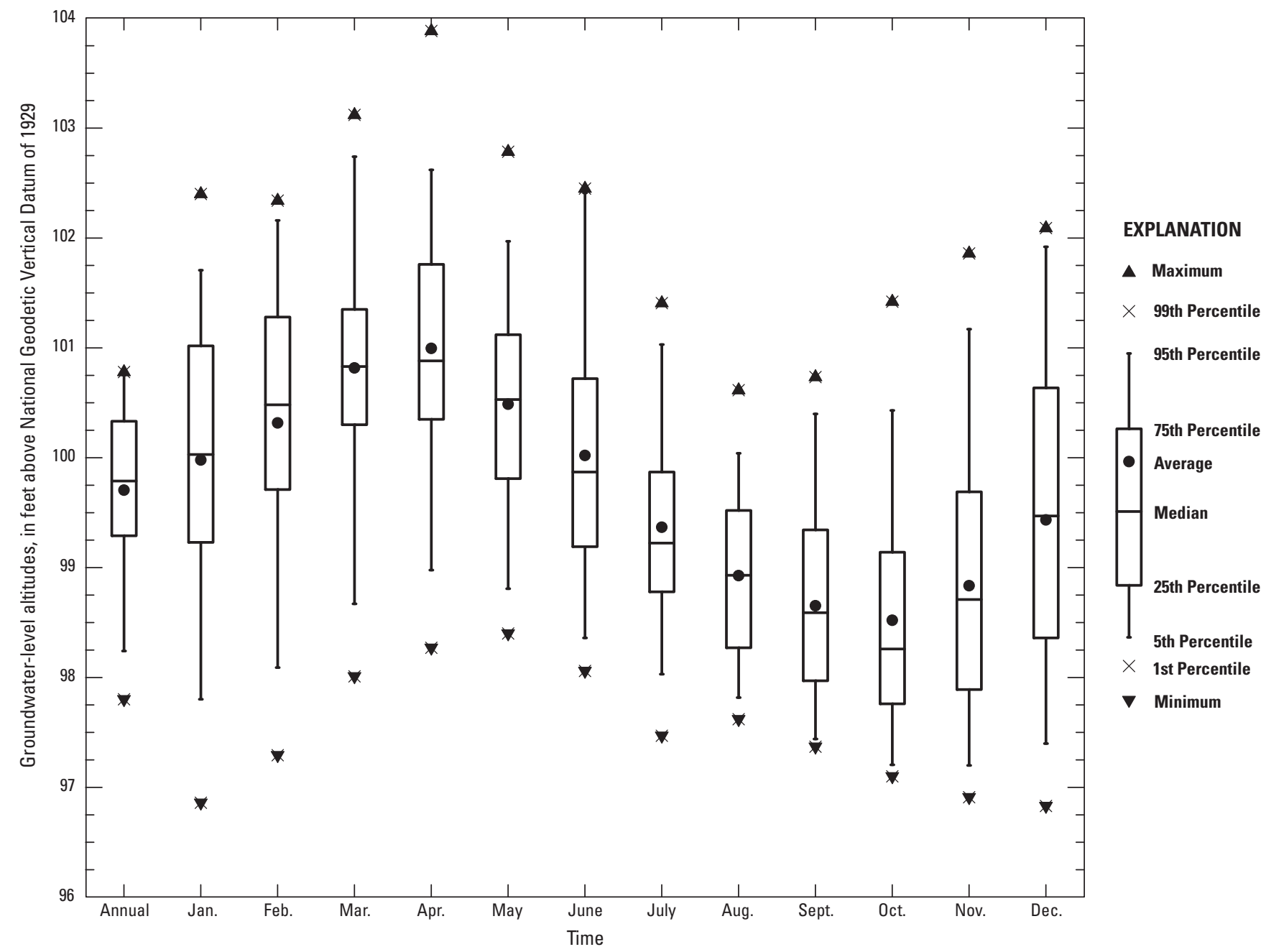

Figure 1-3. Boxplot showing long-term variations in annual-average and monthly-average groundwater-level altitudes in long-term index well SNW 6 from 1960 through 2006. 


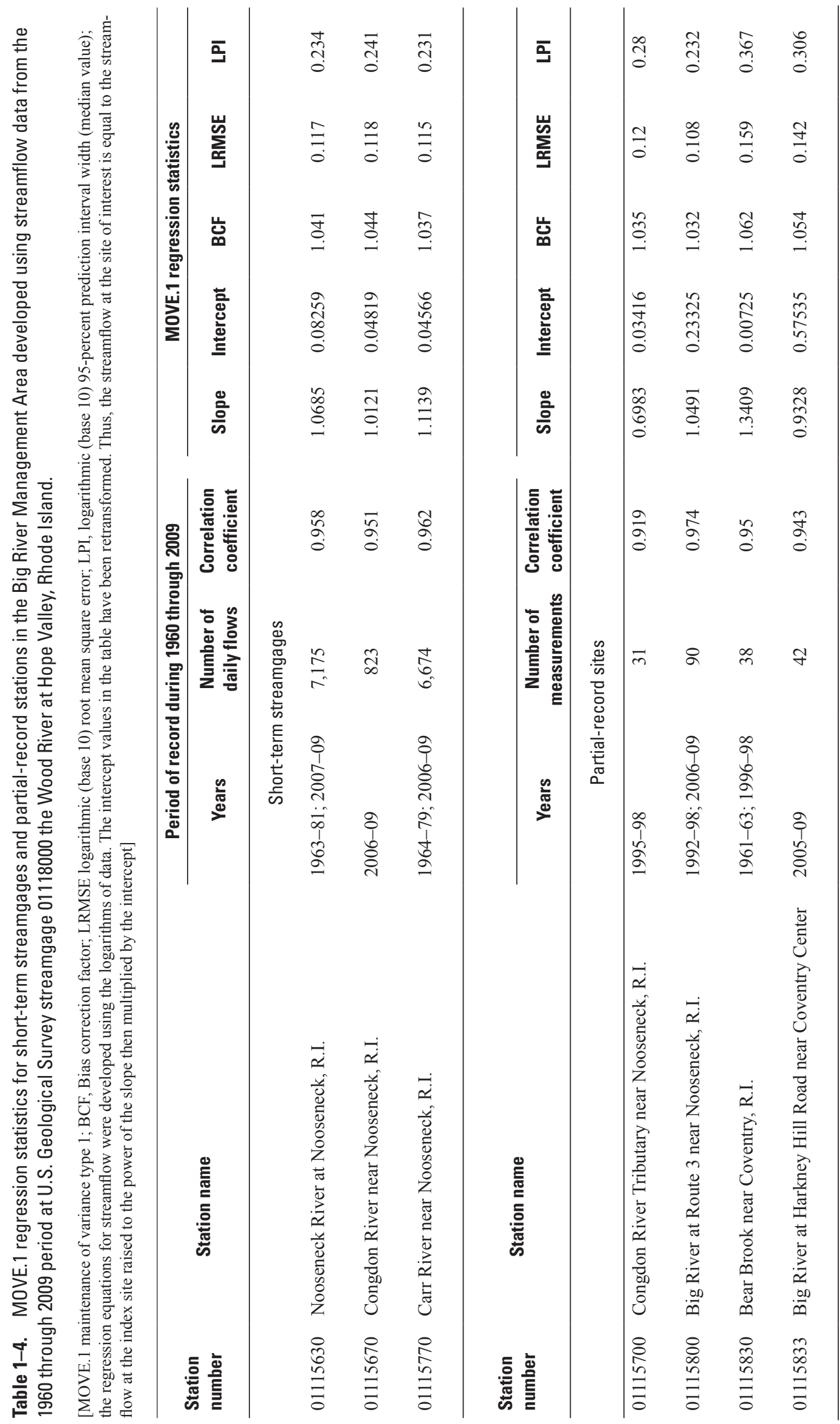




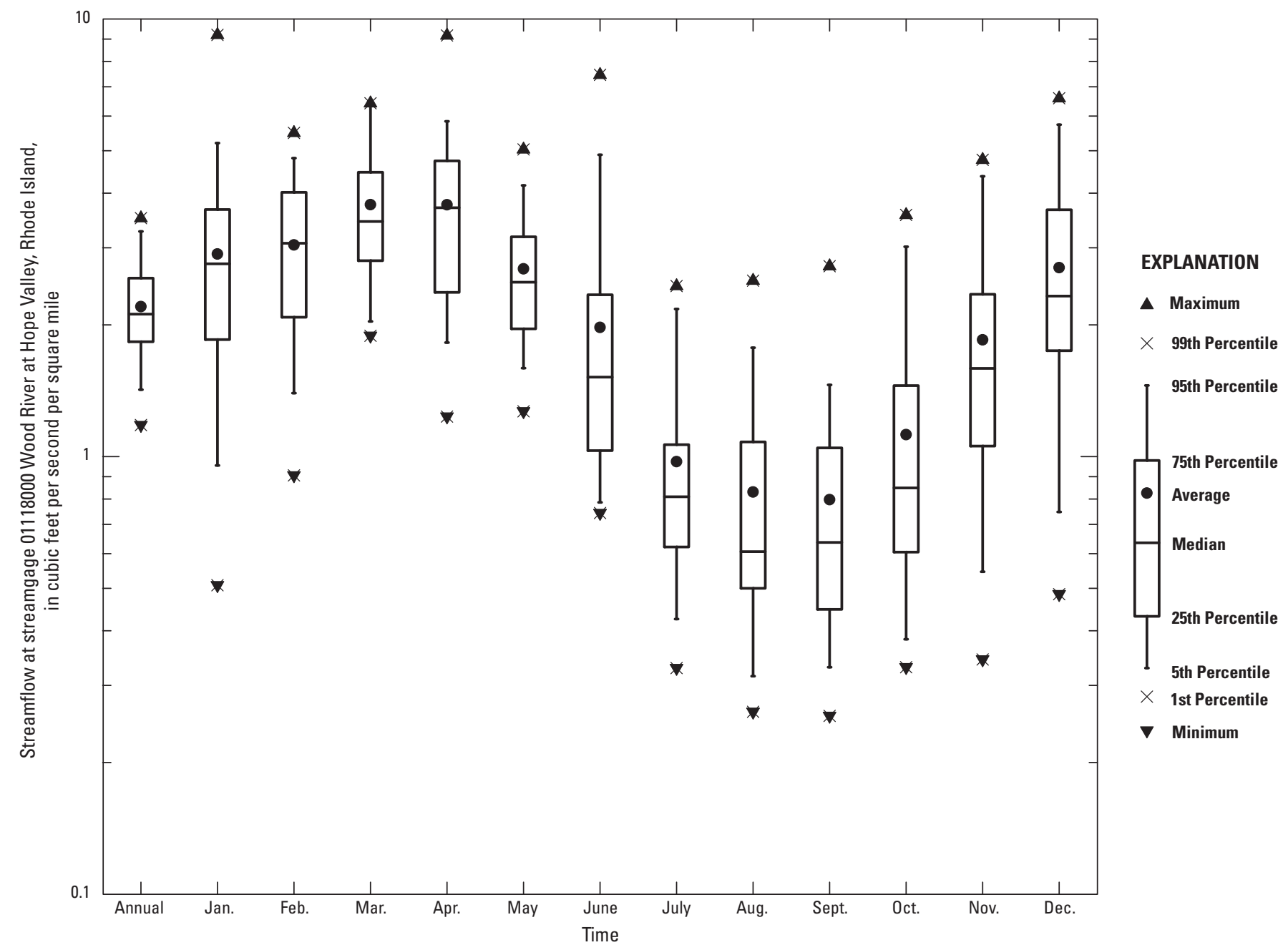

Figure 1-4. Boxplot showing long-term variations in annual-average and monthly-average streamflows at streamgage 01118000 Wood River at Hope Valley, Rhode Island, from 1960 through 2006. 


\section{References Cited}

Frimpter, M.H., 1981, Probable high ground-water levels in Massachusetts: U.S. Geological Survey Open-File Report 80-1205, $22 \mathrm{p}$.

Granato, G.E., 2009, Streamflow Record Extension Facilitator (SREF Version 1.0) - A program for extending and augmenting available streamflow data using long-term streamflow records from hydrologically similar sites, Appendix 3 in Computer programs for obtaining and analyzing daily mean streamflow data from the U.S. Geological Survey National Water Information System Web Site: U.S. Geological Survey Open-File Report 2008-1362, 123 p. on CDROM http://pubs.usgs.gov/of/2008/1362/.

Granato, G.E., Barlow, P.M., and Dickerman, D.C., 2003, Hydrogeology and simulated effects of ground-water withdrawals in the Big River Area, Rhode Island: U.S. Geological Survey Water-Resources Investigations Report 03-4222, $76 \mathrm{p}$.

Helsel, D.R., and Hirsch, R.M., 2002, Statistical methods in water resources-Hydrologic analysis and interpretation: Techniques of Water-Resources Investigations of the U.S. Geological Survey, chap. A3, book 4, 510 p.
Hirsch, R.M., 1982, A comparison of four streamflow record extension techniques: Water Resources Research, v. 18, no. 4, p. 1081-1088.

Hirsch, R.M., and Gilroy, E.J., 1984, Methods of fitting a straight line to data - examples in water resources: Water Resources Bulletin, v. 20, no. 5, p. 705-711.

Ries, K.G., III, and Friesz, P.J., 2000, Methods for estimating low-flow statistics for Massachusetts streams: U.S. Geological Survey Water-Resources Investigations Report 2000-4135, $81 \mathrm{p}$.

Socolow, R.S., Frimpter, M.H., Turtora, Michael, and Bell, R.W., 1994, A technique for estimating ground-water levels at sites in Rhode Island from observation-well data: U.S. Geological Survey Water-Resources Investigations Report 94-4138, $43 \mathrm{p}$.

Zarriello, P.J., 2011, Simulation of water-use and land-use changes on streamflow with a precipitation-runoff model (HSPF), part 2 of Bent, G.C., Zarriello, P.J., Granato, G.E., Masterson, J.P., Walter, D.A., Waite, A.M., and Church, P.E., Simulated effects of water withdrawals and land-use changes on streamflows and groundwater levels in the Pawcatuck River Basin, southwestern Rhode Island and southeastern Connecticut: U.S. Geological Survey Scientific Investigations Report 2009-5127, 254 p. 
This page has been left blank intentionally. 
Prepared by the Pembroke Publishing Service Center.

For more information concerning this report, contact:

Director

U.S. Geological Survey

Massachusetts-Rhode Island Water Science Center 10 Bearfoot Road

Northborough, MA 01532

dc_ma@usgs.gov

or visit our Web site at:

http://ma.water.usgs.gov 

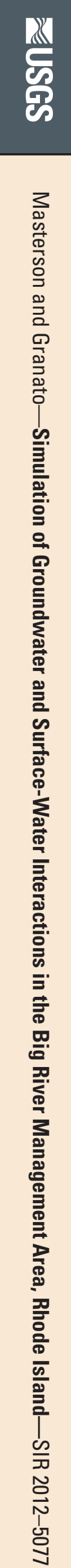